\title{
MOORLAND MANAGEMENT: A STUDY OF EXMOOR
}

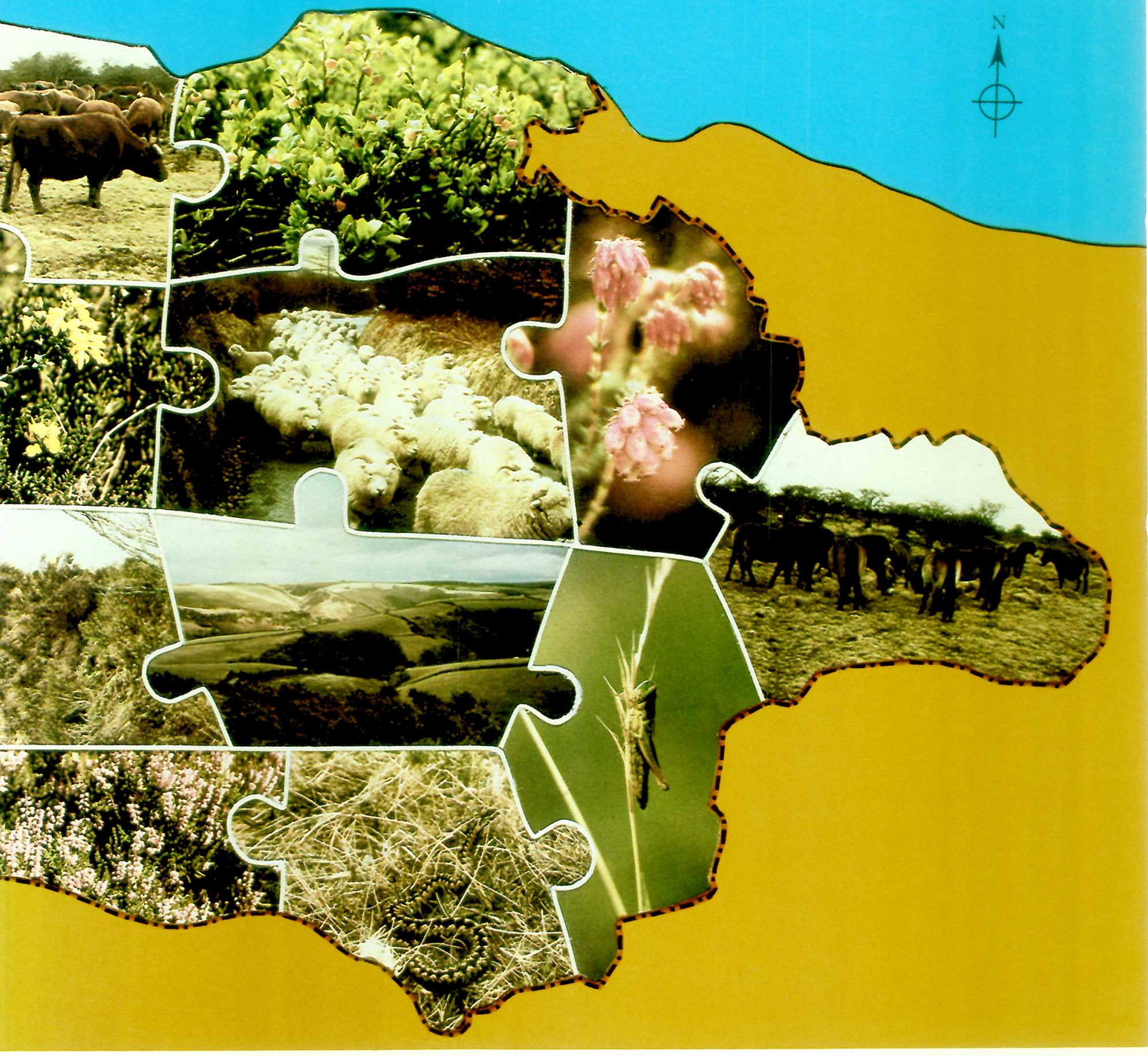

\section{MOTITUTE of TERRESTRIAL ECOLOGY (23)}

(423.5) NATURAL ENVIRONMENT RESEARCH COUNCIL 
i. . .

. 
Natural Environment Research Council

Institute of Terrestrial Ecology

INSTITUTE OF TERRESTRIAL ECOLOGY

LIBRAFY SERYICE

ERINBURGH LABORATORIES

BUSH ESTATE, PENICUIK

MIDLOTHIAN EH26 OQB

MOORLAND MANAGEMENT:

A STUDY OP EXMOOR

A report commissioned by the Countryside Commission

G R Miller, J Miles

Banchory Research Station

Hill of Brathens

Banchory

Kincardineshire

and

o W Heal

Merlewood Research Station

Grange-over-Sands

Cumbria 
Printed in Great Britain by NERC/SERC Reprographic Services, Swindon

C NERC Copyright 1984

Published in 1984 by

Institute of Terrestrial Ecology

68 Hills Road

Cambridge

CB2 1LA

ISBN 0904282791

COVER ILLUSTRATION

Mosaic map of Exmoor by $C$ B Benefield from photographs by $G R$ Miller and $J$ Miles

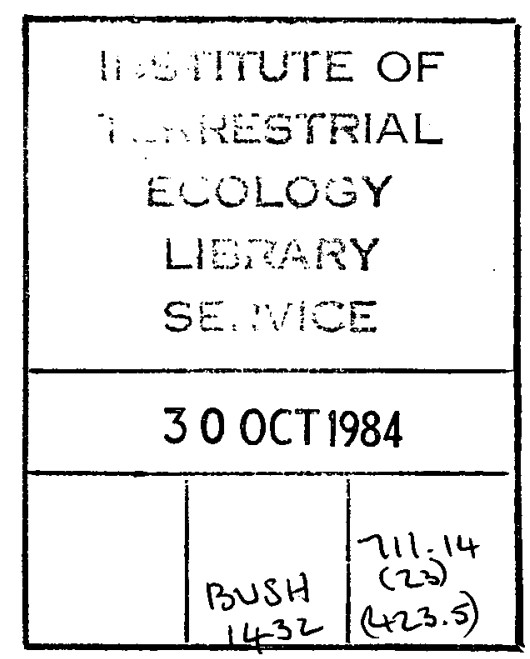

The Institute of Terrestrial Bcology (ITE) was established in 1973, from the former Nature Conservancy's research stations and staff, joined later by the Institute of Tree Blology and the Culture Centre of Algae and Protozoa. ITE contributes to, and draws upon, the collective knowledge of the 14 sister institutes which make up the Natural Environment Research Council, spanning all the envir onmental sciences.

The Institute studies the factors determining the structure, composition and processes of land and freshwater systems, and of individual plant and animal species. It is developing a sounder scientific basis for predicting and modelling environmental trends arising from natural or man-made change. The results of this research are available to those responsible for the protection, management and wise use of our natural resources.

One quarter of ITE's work is research commissioned by customers, such as the Department of Environment, the European Economic Community, the Nature Conservancy Council and the Overseas Development Administration. The remainder is fundamental research supported by NERC.

ITE's expertise is widely used by international organizations in overseas projects and programmes of research.

Dr G R Miller, Dr J Miles Banchory Research Station Hill of Brathens, Glassel BANCHORY

Kincardineshire

AB3 4BY

03302 (Banchory) 3434
Dr 0 W Heal

Mer lewood Research Station

GRANGE-OVER-SANDS

Cumbria

LAl1 $6 \mathrm{JU}$

04484 (Grange-over-Sands) 2264 
2 PHYSICAL AND BIOLOGICAL FEATURES OF EXMOOR 9

2.1 Regional divisions

2.2 Physical environment

2.2.1 Land form and geology 9

2.2.2 Climate 11

2.2 .3 Soils 11

2.3 Wild plants. 13

2.3.1 Flora 13

2.3.2 Vegetation 16

2.3.3 Growth of the heather 22

2.4 Wild animals 22

2.4.1 Red deer 22

2.4.2 Other mammals 25

2.4 .3 Game birds 26

2.4 .4 Predatory birds 28

2.4 .5 Other moorland birds 28

2.4.6 Reptiles and amphibians 35

2.4.7 Invertebrates $\quad 35$

3 PRESENT AGRICULTURAL USE OF THE MOORLAND 36

3.1 Farming system 36

3.2 Changes in stocking rate 37

3.3 Nutritive value of the vegetation to ruminants 40

3.4 Conversion of moorland 41

3.5 Burning 46

3.5.1 Heather moors 46

3.5.2 Grass moors 47

4 NON-AGRICULTURAL USE OF THE MOORLAND 49

5 ECOLOGICAL BASIS FOR MANAGING HEATHER MOORLAND 51

5.1 Biology of the heather 51

5.1 .1 Phases of the life cycle 51

5.1 .2 Regeneration after fire 52

5.1 .3 Response to defoliation 53

5.2 Options for managing heather 54

5.2.1 Grazing 54

5.2.2 Burning 55

5.2.3 Cutting 59

5.2 .4 Fertilizing 60

5.2.5 Other management options 61 
6.1 Losses from the flora $\quad 62$

6.2 Stability of the vegetation $\quad 63$

6.2.1 Invasive species $\quad 66$

6.2.1.1 Purple moor-grass 66

6.2 .1 .2 Gorse 69

$\begin{array}{ll}6.2 .1 .3 \text { Bracken } & 71\end{array}$

6.2 .1 .4 Trees and shrubs 72

6.2.1.5 Rushes 74

6.2.2 Possible changes in heather moors 74

6.2.3 Possible changes in grass moors 75

6.3 Red deer $\quad 76$

6.4 Birds of particular interest $\quad 76$

6.4.1 Red grouse $\quad 76$

$\begin{array}{lll}6.4 .2 & \text { Black grouse } & 78\end{array}$

$\begin{array}{lll}6.4 .3 & \text { Merlin } & 79\end{array}$

6.5 Other birds $\quad 80$

6.6 Possible losses of nutrients $\quad 80$

7 ALTERNATIVE MANAGEMENT AND ITS POSSIBLE EFFECTS 82

7.1 Intensification of grazing pressure 86

7.2 Introduction of controlled rotational burning of heather 90

7.3 Decrease in grazing pressures and burning frequency 92

7.4 Application of fertilizers 94

7.5 Landscape management $\quad 95$

8 FUTURE WORK 96

9 ACKNOWLEDGEMENTS $\quad 97$

$\begin{array}{lr}\text { REFERENCES } & 98\end{array}$

APPENDICES

$\begin{array}{ll}\text { Append Ix } 1 & 103\end{array}$

$\begin{array}{lr}\text { Append1x } 2 & 104\end{array}$

$\begin{array}{lr}\text { Appendix } 3 & 105\end{array}$

$\begin{array}{lr}\text { Appendix } 4 & 107\end{array}$

$\begin{array}{lr}\text { Appendix } 5 & 109\end{array}$

$\begin{array}{lr}\text { Append 1x } 6 & 110\end{array}$

Append1 7 7 114

$\begin{array}{lr}\text { Appendix } 8 & 115\end{array}$ 


\section{SURMARY}

\section{Physical and biological features}

The Exmoor National Park is a 300-500 metres high plateau, formed from sedimentary rocks and dissected by steep-sided valleys. The climate is mild and wet, with a longer growing season than on most other British moorlands. Freely drained mineral soils are more extensive than on other upland areas.

The 19000 hectares of moorland can be divided into coastal heaths, northern heather moors, central grass moors, southern heather moors and Brendon heaths. The moorland vegetation is diverse, due to variations in soil and drainage, and to a long history of burning and of grazing by domestic stock. The flora is not fully documented, and none of the 3 existing studies of the vegetation provide an adequate baseline for future monitoring. The heather seems to be more productive than it is on other British moorlands, probably because of relatively fertile soils, warmer summer temperatures, and a longer growing season at Exmoor.

The National Park supports 700-900 red deer, chiefly living in woodland. They are in no danger of extinction. Populations of other mammals are probably safe also, but black and red grouse are few and may be on the verge of extinction. Amongst raptors, only kestrel and merlin breed regularly on the moors. The merlin reaches its southernmost breeding limit here, but its continuing presence is uncertain. Many other moorland birds attain high densities. The northern heather moors, with structurally diverse vegetation, probably have most bird species, whereas the central grass moors have fewest species. Information on reptiles, amphibians and invertebrates was not examined in deta11.

Agricultural use

Most Exmoor farmers use rough grazing in summer only, when their inbye land is producing winter feed. The probable nutritive value of the moorland vegetation to ruminants is assessed from digestibility studies elsewhere in Britain. Parish data indicate a 50\% increase in the overall density of livestock in 1952-72. However, changes in stocking density on the moors are not clear. Less hardy, more productive breeds of sheep have become more popular as a result of moorland improvement and the provision of winter housing.

Current economics, and favourable land form and soil conditions, encourage conversion of moorland to seeded grassland. Estimates of the rate of conversion vary from 60 ha to 300 ha per year. Losses of moorland have been greatest on the Brendon heaths, least on the wet, peaty grass moors. of the remaining heather moorland, 30-60\% could be converted to grassland.

\section{Other uses}

Field sports, especially deer and fox hunting, are a major activity. About 200 deer are killed selectively each year. Grouse shooting is a minor activity.

Exmoor attracts many casual visitors but their impact is largely restricted to car parks and road verges. On the moors, most visitors keep to footpaths and bridle-paths. 
Heather management

Heather is the staple diet of red grouse and is also important for out-wintered sheep. The physiological ageing of heather can be delayed by controlled grazing. However, most heather needs periodic burning to keep it young and vigorous. Mechanical cutting is slow, often impracticable, and of uncertain result. Heather is therefore usually burnt.

Regeneration after burning is most rapid and complete when plants are 20-30 centimetres tall and still fairly young. The frequency of burning is therefore geared to the heather's rate of growth. Burning too frequently, coupled with heavy grazing, causes rapid conversion of heather moorland to grassland; such a change can be accelerated by liming and fertilizing. Allowing heather to become too old inhibits its regeneration after burning and can also encourage the dominance of grasses.

On Exmoor, most heather needs to be burnt rotationally every 6-12 years. In practice, heather burning is mostly indiscriminate and uncontrolled because of (i) accidental fires, (ii) opportunistic burning due to wet weather, (iii) few large areas being in single ownership, (iv) heather not being regarded as an important resource, and ( $v$ ) grouse shooting not being a major sport. By contrast, there is a coherent burning policy for livestock on the large block of grass moor under single ownership.

Consequences of present management

Some locally rare plant species may have declined or become extinct as a result of repeated burning, draining and grazing. Few trees and shrubs can colonize the moors, hawthorn being the most frequent invader.

Three species of little economic value have become widespread and may be spreading further. Purple moor-grass appears to be increasing locally on the northern heather moors, more widely on the southern heather moors. At some places, it is so abundant and the remaining heather so old that the complete loss of the heather seems inevitable. Gorse, widespread on roadsides and around the edges of the moors, has probably increased locally over the last 20-30 years. Bracken, which is encouraged by haphazard burning, is ubiquitous. The control of these 3 species is discussed. All can be killed by chemical herbicides.

Apart from conversion to seeded grassland, the present management at Exmoor seems to be causing a progressive loss of heather cover. Extensive tracts of pure, apparently stable, heather remain only on the northern heather moors. Elsewhere, heather cover is declining. Heavy grazing encourages the spread of grasses at the fringes of the heather moors, and haphazard burning weakens the dominance of heather in the hinterland. Fragmentation of the heather moors makes them more vulnerable to such changes. The central grass moors probably have relatively stable vegetation.

The future of red grouse on Exmoor is inevitably linked with that of heather. The lack of carefully planned and controlled burning of small patches probably results in grouse numbers fluctuating at a very low level. Predation probably contributes to the small stock, but human disturbance is unlikely to affect numbers at present. The most effective conservation measure for black grouse would be to encourage tall, dense heather, with birch and hazel scrub, at the edge of the moor, and possibly to establish small conifer plantations. The numbers of small moorland birds appear adequate to support a low density of mer1ins. Merlins, 
however, need large territories and their numbers may be limited by the small patches of remaining heather moor.

Possible alternative management

Current grazing pressures on the heather moors are not known. The overall stocking is probably equivalent to about 2.5 sheep per hectare, varying locally to 6-7 sheep per hectare in July-0ctober. Above about 2.5 sheep per hectare, heather tends to be replaced by grasses. Thus, only a small increase in grazing pressure might cause a rapid change of heather moor land to various kinds of grassland.

Controlled burning is needed to halt the replacement of heather by grasses and bracken, although the heather in some areas may be beyond regeneration. Patchwork burning would increase the numbers of grouse and might also increase the variety of invertebrates and small birds. Controlled burning might improve livestock production; out-wintered sheep, particularly the hardier breeds, would benefit most. A change to hardier stock could reduce the need for reclamation and increase the agricultural use of the moorland.

Reduction in grazing pressure and burning frequency would allow colonization of the heather moors by shrubs and trees. Rapid scrub invasion might occur locally, but, in general, predominant scrub cover might take 100-200 years to develop. Large expanses of grass moor without dwarf shrubs might take 100 years to change substantially to heather moorland, and even longer to change to scrub and woodland.

Application of fertilizers to the moor would increase the production and digestibility of the herbage. However, the increased grazing would cause the replacement of heather and bilberry by grasses.

Management of the heather moors by controlled burning and grazing could be supplemented by direct seeding to re-establish heather dominance on grass moor or on areas where heather is declining.

\section{Future work}

The greatest needs for information relevant to the management of the vegetation are (1) the current stocking rates of sheep, cattle and horses on the moors, (i1) the frequency and distribution of burning, and (iii) the direction and rate of successional changes. 


\section{INTRODUCTION}

In 1979, the Countryside Commission financed a study of moorland management in Exmoor National Park. The aim was to produce a summary of current knowledge which might be of value to land managers, not only at Exmoor but also at other National Parks in England and Wales. Much has been made of data originating from Scotland, where there is a long experience of the problems involved in managing heather moors. However, the Exmoor environment is very different from that of northern Britain and there remains a need for further field investigations.

This report, compiled within 4 months, is based on the results of 2 brief visits to Exmoor in late winter and on a review of relevant literature avallable up to 1979. Publication has been delayed due to circumstances beyond the authors' control. Although some new work on moor management has been published since 1979, we are not aware of any developments that would materially alter our conclusions or recommendations. The report, therefore, stands as originally presented to the Countryside Commission, apart from a few editorial changes.

The specific objectives of the study were to examine:

i. current knowledge of the populations and distribution of flora and fauna on Exmoor;

11. the impact of existing and alternative management systems on the populations of particular species;

iii. the nutritive values of different plant communities and mixtures of communities under the management systems identified in ( $v$ ) and (vi);

1v. the management required to maintain different types of moorland, especially heather moor;

v. changes in vegetation 11kely to result from a continuation of existing management systems, stocking rates and periods of stocking;

vi. alternative management systems developed in the United Kingdom, and the possible changes in vegetation which are likely to result if they were introduced on Exmoor.

Before examining the moorlands of Exmoor in detail, it is relevant to place Exmoor in a national context, Indicating the extent to which it has characteristics and problems in common with other upland areas. The 69000 hectares of the Exmoor National Park comprise about $3 \%$ of the uplands in England and Wales. These upland areas are a major land resource within a small country. Although their production potential is constrained by climatic and soll conditions, uplands make important contributions to agriculture through sheep and cattle rearing, with extensive areas of unmanaged rough grazing. In terms of forest production, most of the commerclal forests of Britain are sited in the uplands, and it is probable that future demands will increase the area of afforestation there. In addition, the uplands represent a major area for water catchment.

Thus, although there is extensive use of these upland areas, intensive use involving practical land management is very limited. The limited intensity of use means that the uplands constitute a major resource for wildiffe, 
with a wide range of plant and animal communities whose characteristics are determined more by variations in soil and climate than by man. The relatively open landscape and atmosphere of 'wilderness', combined with the often dramatic land forms and the limited restriction of access, have been responsible for the designation of much of the uplands ( 1.3 million hectares) as National Parks. Their purpose is to preserve and enhance the natural beauty of these areas and to promote their enjoyment by the public, with due regard for the needs of agriculture and forestry and for the economic and social interests of rural areas.

Nine of the 10 designated National Parks in Britain are predominantly upland and, although they cover much of the uplands in England and Wales, they show distinctive features of landscape and land use reflecting their natural physical features. A characterization of the physical features in units of $10 \quad 000$ hectares ( 10 x 10 kilometre grid squares) allows a comparison of the main areas of upland and the National Parks in England and Wales (ITF 1978). Eight land classes were defined and their basic features are summarized in Table 1.1 , with classes $1-4$ representing 'marginal' areas of upland and classes 5-8 the 'central' upland areas. Those basic features indicate the type of physical landscape and also the potential of the land for agricultural or forestry production. The distribution of land classes in the 9 National Parks (Table 1.2) shows that the Northumberland, North York Moors, Exmoor and Dartmoor National Parks are distinct from the other Parks in being predominantly marginal in character, ie with relatively low altitude and relief and gentle slopes. The Exmoor and Dartmoor Parks are distinct in having a high proportion of land classes 1 and 2 .

However, the land classes are ranked in Table 1.2 by their relative potential for agriculture, class 3 having the greatest potential (only $3 \%$ of land is in this class), and class 5 having the least potential (69\% in this class). Because of the size of the units used in the classification, some of the grid squares contain land which is outside the Park boundaries and there is variation within the land in each grid square. However, the comparison between Parks indicates 2 features relevant to the present study: first, Exmoor and Dartmoor contain a major proportion of a land and landscape type which is poorly represented in other Parks; second, agricultural use and potential are greater in these 2 Parks than in the others, providing a different type of landscape as well as a greater potential for uses. The distinction between the Exmoor and Dartmoor National Parks requires a finer level of analysis than is available from these data, but in general the land on Exmoor has a lower altitude and relief, slightly higher temperatures, and more fertile parent rock than Dartmoor.

While the above comparison shows the distinctive features of the Exmoor National Park, it is the moorland which is of concern here. The extensive tracts of heather moorland on Exmoor represent a type of vegetation, with its associated visual attraction, which is very widespread in Scotland and, to a lesser extent, northern England. However, no characteristic of the Exmoor moorland distinguishes it from other heather moors in Britain. It is valuable in terms of landscape conservation because it is one of only 2 large areas of heather moor in southern England. The close proximity of good agricultural land and the inherent fertility of the moorland make the moor particularly liable to agricultural development. In this respect, it differs from most other heather moors, with the exception of the North York Moors where there has also been considerable enclosure of heather moor and 


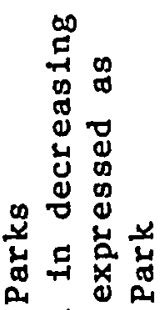

岁

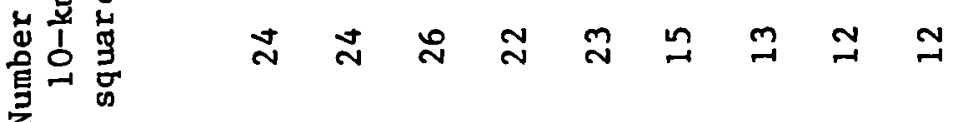

- $\mathcal{D} 0-1$

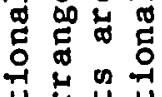

苛嵒出

の 㟧

อ $\infty \propto ⿻ 上 丨$

ஸें

常

g

g

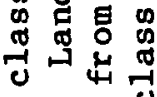

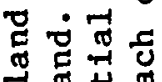

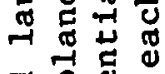

冠焉

공ㅁㄷ

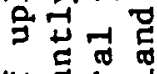

4 离

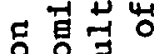

年号总

苟㞾苟

苟嵒出

नी

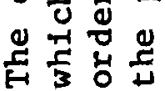

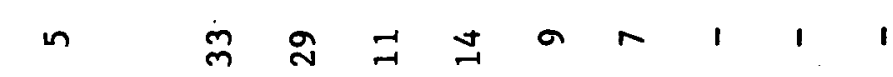

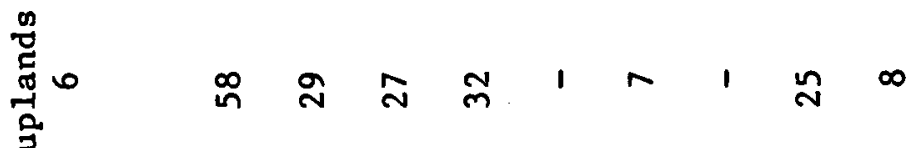

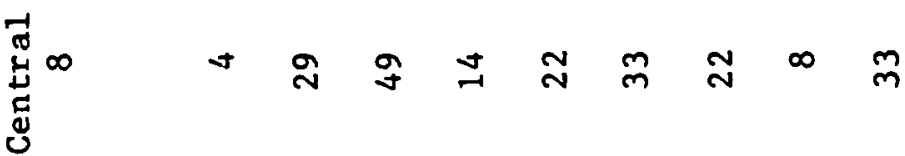

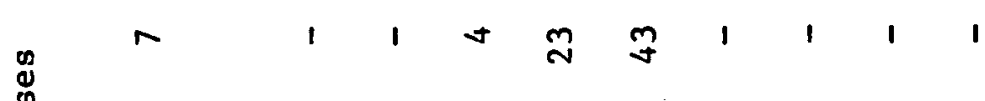

$N$
-1
0
-1
0
0
-1

章

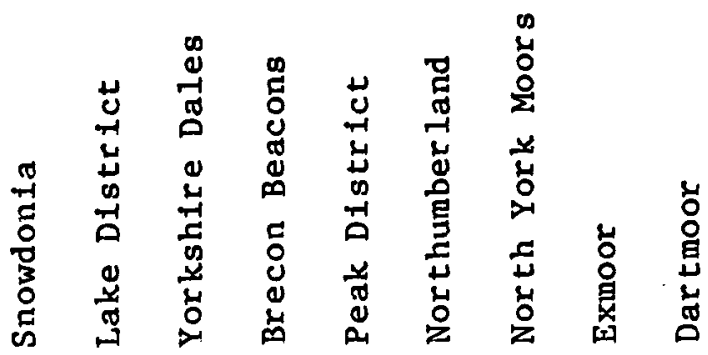


conversion to pasture. One distinction between the heather moorlands of Exmoor and the North York Moors is that much of the latter is actively managed for grouse, thus providing an incentive for the land owners both to retain the moor, and actively to manage it for heather.

As stated by Porchester (1977), the problem of the future of the moorland in the Exmoor National Park' can be represented as a conflict between increased agricultural production from moorland and the need to maintain the existing balance of the Exmoor landscape. For sound farming reasons, farmers have converted moorland to improve their holdings' stock-carrying capacity and may continue to do so. This has the effect of gradually diminishing the areas of moorland which conservationists rightly say - and many farmers admit - is one of the main characteristics of Exmoor and one of the reasons for its original designation as a National Park'. 


\section{PHYSICAL AND BIOLOGICAL FEATURES OF EXMOOR}

\subsection{Regional divisions}

There are some 19000 ha of moorland in the Exmoor National Park (Porchester 1977), and Figure 2.1 indicates the location and extent of the main blocks. The map actually shows only the 17000 ha designated 'Critical Amenity Area' (Exmoor National Park Committee 1977). Nonetheless, it illustrates the extent to which the moorland is fragmented, particularly around the edges of the Park.

It is convenient to divide the moorland into 5 regions: (1) coastal heaths, (ii) northern heather moors, (iii) central grass moors, (iv) southern heather moors, and (v) Brendon heaths. These regions (Figure 2.1), defined in terms of their predominant vegetation and geographical separation from one another, were proposed by Sinclalr (1966) and used for his description of the vegetation of Exmoor (Sinclair 1970).

The coastal heaths are fragmentary, being scattered along the coastal strip from Holdstone Down in the west to North Hill in the east. They are characterized by the predominance of heather (Calluna vulgaris), in association with be11 heather (Erica cinerea) and dwarf furze (Ulex galli1). The northern heather moors, also with heather predominant but with dwar f furze less conspicuous in the vegetation, form the main block of moor land, and stretch more or less continuously in a crescent $1-5 \mathrm{~km}$ wide from Challacombe Common in Devon to Dunkery Hill in Somerset. Lying to the south are the central grass moors where heather is sparse and there is a predominance of purple moor-grass (Molinea caerulea) and other grasses. The region of grass moors is contained within the boundary of the parish of Exmoor Forest. The southern heather moors occur as several blocks from Shoulsbarrow Common on the south-west flank of Exmoor Forest eastwards to Winsford Hill. Finally, the Brendon heaths comprise pockets of heathery vegetation scattered through the Brendon Hills to the east of the valley of the Rivers Quarme and Exe.

\subsection{Physical environment}

\subsubsection{Land form and geology}

Much of the moorland within the Park is on plateaux varying from some $300 \mathrm{~m}$ above sea level to $500 \mathrm{~m}$ at the highest point, Dunkery Beacon. The hills are generally rounded, with only gentle slopes, and, apart from the coastal cliffs, the area lacks the steep rocky outcrops and crags characteristic of many of the British uplands. The plateaux are, however, dissected by steep-sided valleys (often $20^{\circ}-30^{\circ}$ slope) marking the courses of the main rivers, the Lyn, the Barle and the Exe, and their numerous tributaries.

Detalled geological information about the wide varlety of rock types in the area was not readily avallable. Exmoor is overlaid by sedimentary rocks from the Devonian period. These comprise mainly slates, shales, sandstones and grits, with occasional outcroppings of siliclfied limestone. The strata appear as bands running from west to east. Although fairly hard and resistant, these sediments are nonetheless more easily weathered than the rocks of Dartmoor and much of upland Britain. 


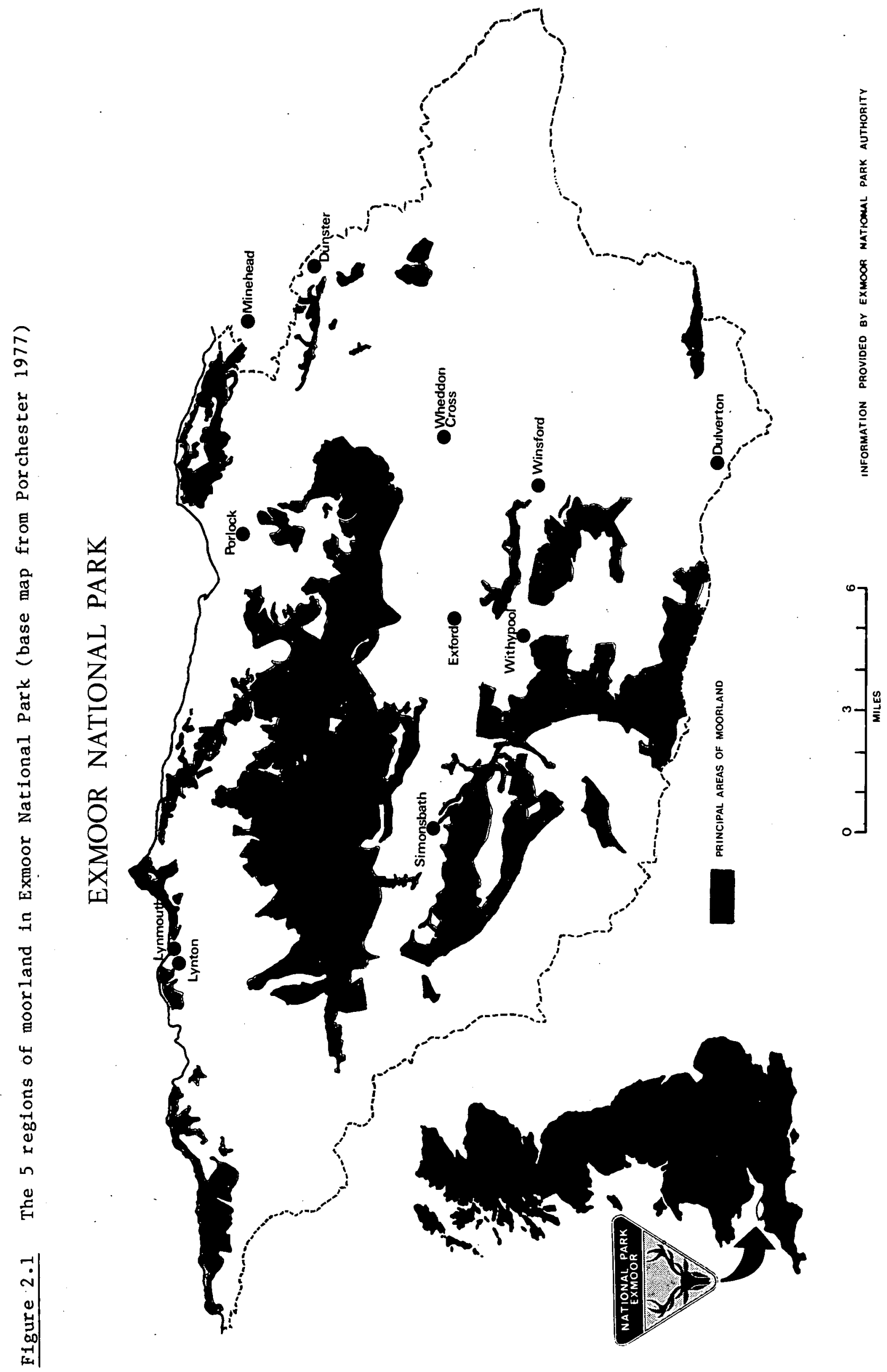




\subsubsection{Climate}

Situated at the south-west corner of Britain, Exmoor has a mild but relatively wet climate. Records from Liscombe Experimental Husbandry Farm, located at $305 \mathrm{~m}$ altitude (Table 2.1), show an annual mean temperature of $8.4^{\circ} \mathrm{C}$, ranging from $3.2^{\circ} \mathrm{C}$ in January to $14.1^{\circ} \mathrm{C}$ in July. The annual accumulated temperature, which estimates the energy available for plant growth above a threshold temperature of $5.6^{\circ} \mathrm{C}$, amounts to some $1500 \mathrm{day}^{\circ} \mathrm{C}$ at Liscombe (Ministry of Agriculture, Fisheries and Food 1978). At similar altitudes in the Scottish Highlands, accumulated temperatures are considerably less, 800-1100 day ${ }^{\circ} \mathrm{C}$ (Birse \& Dry 1970).

The average length of the growing season at Liscombe is 244 days (Curtis 1971), nearly 50 days longer than the season at $300 \mathrm{~m}$ elevation in southern Scotland and northern England (Gloyne 1968). Assuming a lapse rate of 30 days per $100 \mathrm{~m}$ of altitude (Gloyne 1958), even at Dunkery Beacon there are 180 days available for growth in an average year. Thus, in terms both of length of growing season and of energy avallable for growth, Exmoor compares favourably with other moorland areas further north.

Annual precipitation at Exmoor is strongly influenced by ground rellef and by the rain-bearing westerly winds. Most rain falls on high ground to the west, decreasing at lower altitudes and towards the east (Revesz 1969). Thus, annual precipitation is nearly $2000 \mathrm{~mm}$ at Chains Barrow (altitude 487 $\mathrm{m}$ ), about $1700 \mathrm{~mm}$ at Dunkery Hill (altitude $500 \mathrm{~m}$ but $16 \mathrm{~km}$ to the east), and on $1 \mathrm{y} 1200 \mathrm{~mm}$ at the east end of the Brendon Hills $(400 \mathrm{~m})$. Liscombe, at the south-eastern edge of Exmoor, receives $1460 \mathrm{~mm}$ (Table 2.1). There is a notable seasonality in the precipitation, November-January being a particularly wet period and June the driest month.

\section{$2 \cdot 2.3$ Soils}

In 1979, detailed information had been published only for the parish of Exmoor Forest (Curtis 1971). The Soll Survey of England and Wales has now published Sheet SS 63 (Brayford) of the Ordnance Survey $1: 25000$ Series of maps and will produce Sheet SS 74 (Lynton) early in 1984. Some soll mapping has also been done by students from Bristol University, under the supervision of Dr L F Curtis.

The soil map of Exmoor Forest shows 4 major soll groups - brown earths, gleys, podzols and peats, respectively amounting to $15 \%, 20 \%, 18 \%$ and $16 \%$ of the area mapped. A fifth group, comprising a podzol/brown earth/gley complex (the so-called 'Exmoor complex') and small areas of alluvium and flushes, accounts for the remaining $31 \%$. The peat is centred mainly on the plateau of the Chains, where rainfall is high and evapotranspiration presumably low. Below about $400 \mathrm{~m}$, many of the deep mineral soils, especially the peaty gleyed podzols, gleys and brown earths, have been ploughed and the vegetation converted to sown grassland.

Other parts of Exmoor probably have a similar predominance of potentially freely-drained mineral soils derived from the underlying sedimentary rocks. Because of the lower rainfall, peat is less extensive elsewhere than it is on the Chains. Indeed, an analysis of the published $1: 1000000$ soil map of England and Wales (Soil Survey of England and Wales 1974) shows that Exmoor has a much greater proportion of ground with wel1-drained mineral soils (85\%) than any other upland area of England or Wales (Ball 1978). Relatively stony, iron-humus podzols and gleyed podzols probably predominate amongst the soils underlying the heather moors that surround 


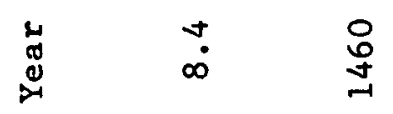

¿

$\begin{array}{lll}r & m & 0 \\ 0 & 0 & \ddots\end{array}$

\begin{tabular}{lll}
$ப$ & $\infty$ & \multirow{2}{*}{}
\end{tabular}

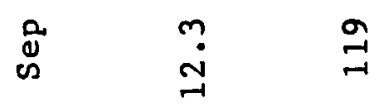

$\stackrel{\infty}{3} \quad \exists \quad \Xi$

$\begin{array}{lll}3 & 0 & 9 \\ 5 & \pm & \end{array}$

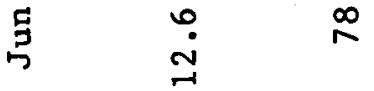

¿

台

夏 向

童

목

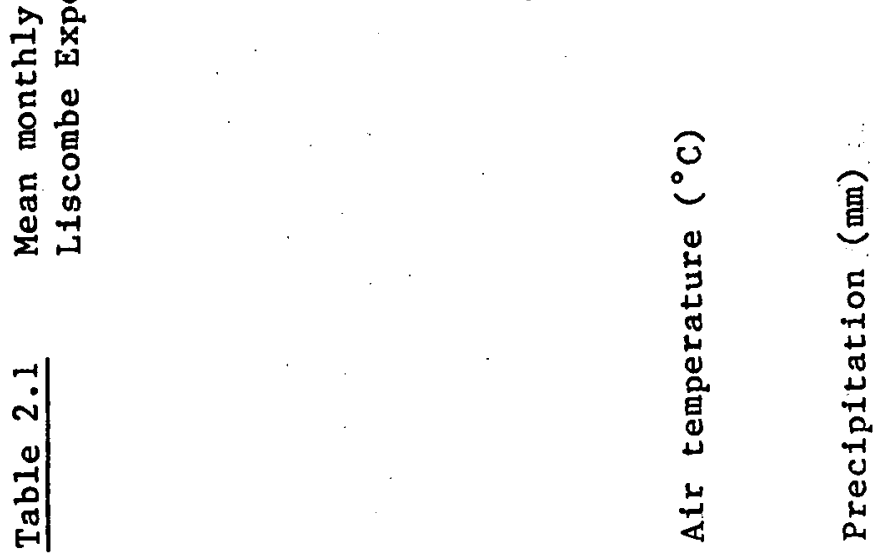


Exmoor Forest. Conversion to grassland has presumably been undertaken on most of the deeper gleys and brown earths that are accessible to machinery. The soils of the Brendon Hills, where rainfall is generally lower than it is elsewhere on Exmoor, appear to be medium-textured acid brown earths and these have been extensively ploughed and seeded.

\subsection{Wild plants}

\subsubsection{Flor a}

There is no definitive work on the flora of Exmoor. A preliminary checklist was recently published (Giddens 1977), based on plants recorded over a 3-year period by members of the Exmoor Natural History Society. However, the author notes that many species recorded earlier may still be present, although they have not yet been re-located by the Society. Apart from this checklist, inferences may be drawn from the Atlas of the British Flora (Perring \& Walters 1962, 1975), a comprehensive account of vascular plant species in the United Kingdom. This Atlas records species presence in the $10-\mathrm{km}$ squares of the National Grid. The Exmoor National Park falls within 14 grid squares but the square containing South Molton, with less than $0.1 \%$ of its area falling within the Park, can effectively be ignored. However, because only 3 grid squares fall entirely within the Park, it is not known which of the species recorded in the remaining 10 squares actually occur within the Park. There has not been sufficient time under the contract to search for vascular plant records in other sources, or for any records of non-vascular plants.

From the Atlas of the British Flora, Sinclair (1970) 1isted 31 species as having become 'extinct' on Exmoor since 1930, and noted that most are heath and moorland species. However, this conclusion misinterprets the original source.

1. The 'extinct' species have merely not been found since 1930. It is therefore not certain that they are extinct.

i1. The list is incomplete.

ii1. Two of the 31 species were misclassified, le they are not shown in the Atlas as occurring on Exmoor.

iv. Five of the 31 species were naturalized introductions, and their status can hardly be considered in the same light as natives.

v Only about a third of the species are arguably species of heath and moor land, not 'most'.

Re-analysis of the Atlas suggests that 46 vascular species have not been recorded since 1930 in the $1310-\mathrm{km}$ grid squares of the National Park. However, at most only 13 , or $28 \%$, could be considered as species of heath or moorland (Table 2.2). Their distributions suggest that their apparent decline on Exmoor is part of a more general decline nationally, either because of loss of suitable habitat through draining, reclamation or other activities, or because of other factors such as long-term climatic change.

Table 2.3 lists vascular species characteristic of moorland and acid grassland that have been reported as uncommon, local or rare species on Exmoor. Probably the most notable record is that for parsley fern 
Table 2.2 Species not recorded since 1930 in the $1310-\mathrm{km}$ squares of the National Grid corresponding to the Exmoor National Park

$\begin{array}{ll} & \text { Flat-sedge } \\ \text { Moonwort } & \\ \text { Rough hawk's-beard } \\ * \quad \text { Field gentian } \\ \text { * } \quad \text { Heath cudweed } \\ \text { Bog orchid } \\ \text { Alpine clubmoss } \\ \text { Marsh clubmoss } \\ \text { Fir clubmoss } \\ \text { Spiny restharrow } \\ \text { * } \quad \text { Sreater broomrape } \\ \text { Slender tare }\end{array}$

Blysmus compressus

Botrychium lunaria

Crepis biennis

Gentianella campestris

Gnaphalium sylvaticum

Hammarbya paludosa

Lycopodium alpinum

L. inundatum

L. selago

Ononis spinosa

Orobanche rapum-genistae

Teesdalia nudicaulis

Vicia tenuissima

* Former presence in the Park confirmed by Giddens (1977) or other source 
Table 2.3 List of uncommon, local and rare species characteristic of moorland and acid grassland in the Exmoor National Park. Compiled from Giddens (1977), Perring and Walters (1975) and unpublished sources

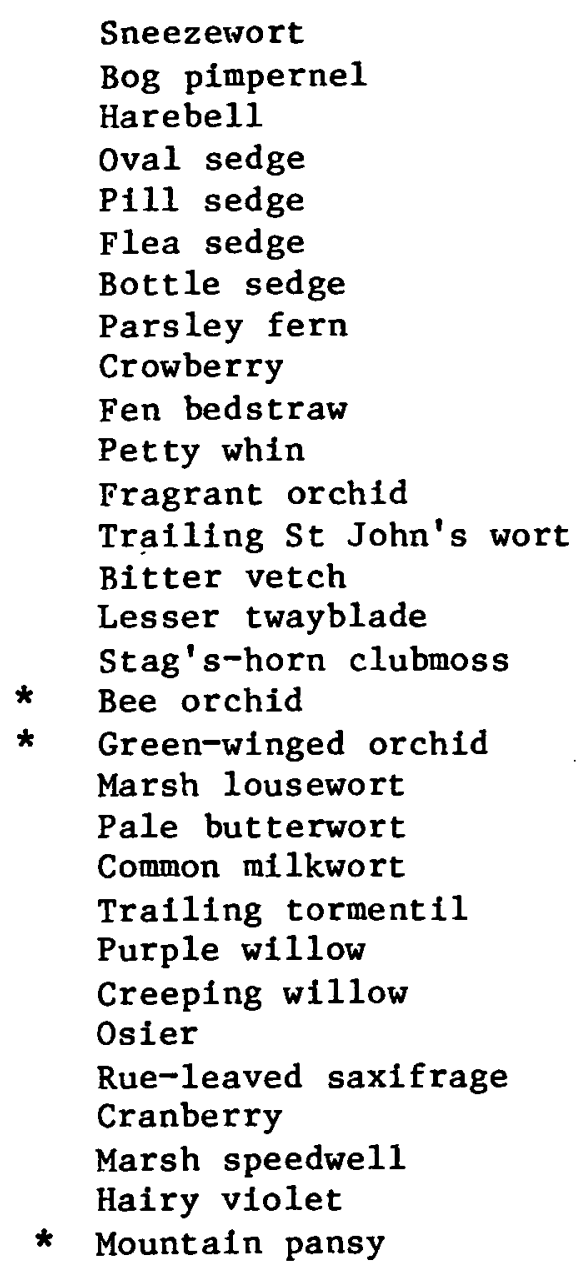

Sneezewort

Bog pimpernel

Oval sedge

P111 sedge

Flea sedge

Bottle sedge

Crowberry

Fen bedstraw

Trailing St John's wort

Bitter vetch

Lesser twayblade

Stag's-horn clubmoss

* Bee orchid

Marsh lousewort

Pale butterwort

Common milkwort

Tralling tormentil

Purple willow

Creeping willow

Osier

Rue-leaved saxifrage

Marsh speedwell

Hairy violet
Mountain pansy

Achillea ptarmica

Anagallis tenella

Campanula rotundifolia

Carex ovalis

C. pilulifera

C. pulicaris

C. rostrata

Cryptogramma crispa

Empetrum nigrum

Galium uliginosum

Genista anglica

Gymnadenia conopsea

Hypericum humifusum

Lathyrus montanus

Listera cordata

Lycopodium clavatum

Ophrys apifera

Orchis morio

Pedicularis palustris

Pinguicula lusitanica

Polygala vulgaris

Potentilla anglica

Salix purpurea

S. repens

S. viminalis

Saxifraga tridactylites

Vaccinium oxycoccus

Veronica scutellata

Viola hirta

Viola lutea

* Noted by Giddens (1977) as old records for Exmoor, but not given by Perring and Walters (1975); possibly misidentified? 
(Cryptogramma crispa). Exmoor contains the only known site for this species in southern England (in fact, south of a Bristol-Scarborough axis). Mountain pansy (Viola lutea) would be equally notable if it occurred on Exmoor, but its status is doubtful (see Table 2.2). None of these rare or uncommon species of Exmoor is rare nationally.

\subsubsection{Vegetation}

There are 3 important sources of information on the moorland vegetation of Exmoor :

\section{i. Sinclair's (1965) vegetation map and (1970) booklet 'The vegetation of Exmoor'.}

11. The vegetation maps of the main blocks of moorland given by Davies and Jarman (1978).

11i. An unpublished phytosociological survey organized by $R$ Williams of the Nature Conservancy Council's Taunton office.

Sinclair's vegetation map of 20500 ha on a 1:15 000 scale was made in 1965 as part of the Second Land Utilization Survey of Great Britain. Sinclair determined mapping units first on the presence of a dominant or predominant species, and then further characterized each unit by noting the other most abundant species in decreasing order of abundance. As a result, a large number of different mapping units was used; the mapping units are regularly characterized by 3 or 4 species, and by 5 or 6 on occasion. Sinclair's (1970) booklet 'The vegetation of Exmoor' is largely based upon this map. It reduces the mapping units into 11 vegetation types, and lists the mapped area of each of these types in each region and sub-region of Exmoor. Appendix 1 shows the relative proportions of these types in the different regions.

The vegetation maps of Davies and Jarman (1978) were produced to give a general impression of the vegetation as background to a study of moorland bird populations during the period March-August 1978. The vegetation mapping units were described in a similar way to that used by Sinclair. In addition, each patch of dominant or abundant heather was characterized as either pioneer (if less than $15 \mathrm{~cm}$ high), building $(15-30 \mathrm{~cm}$ ) or mature (more than $30 \mathrm{~cm}$ ). Appendix 2 shows the relative proportions of a simplified range of vegetation types on 15200 ha in the 4 main regions. The Brendon heaths contain no large moorland blocks and were not mapped in this study.

W111iams' survey was designed to describe quantitatively the vegetation of a11 areas contained in the heather moorland and rough land categories on Sinclair's map. Each patch was characterized by several one metre quadrats in which species were listed and rated on the Domin cover/abundance scale. The sampling method approximated to stratified randomization. Quadrats were placed at a density of about one to every 6 ha, each quadrat being thrown 'at random' within an approximately 6 ha patch. By March 1979, this survey was roughly 75\% completed, with 2365 quadrats described from 14000 ha. The main gaps in coverage were in the coastal heaths, the central grass moors and, in particular, the Brendon heaths, which were still largely undescribed. Williams has classified his quadrats according to the phytosociological scheme of Evans et al. (1977). Appendix 3 shows the relative proportions of these quadrats in the different regions. In addition, for the purposes of this report, we subjectively classified the 
quadrats on the basis of dominance, life form and habitat conditions, following the scheme adopted in the publication 'Upland land use in England and Wales' (ITE 1978), as an aid to interpreting the dynamic status of the vegetation and possible future changes. The relative proportions of these vegetation types are given in Appendix 4.

A further useful source of information on the vegetation of Exmoor is the series of $1: 10$ 000 scale aerial photographs in infra-red colour taken by Meridian Airmaps Limited in 1976. In 1978, Meridian produced an uncontrolled photo-mosaic of Exmoor in black-and-white on a 1:25 000 scale from their 1976 coverage. While this photo-mosaic inevitably contains many small Inaccuracies, it has the advantage of including most of the moorland within the National Park on a single sheet.

Each source of information has its particular values and limitations. Sinclair's moorland vegetation map, while having the advantage of being the only comprehensive map of the area, is now rather too old to give a reliable picture of present-day moorland vegetation. In particular, substantial changes could have occurred over the intervening 14 years in the areas dominated by heather, bracken (Pteridium aquilinum) or gorse (Ulex europaeus). Davies and Jarman's map is up-to-date, but covers only about $80 \%$ of the moorlands, omitting the Brendon heaths in particular. Williams' survey is also up-to-date, but, apart from the limitations inherent in his subjective approach, probably underestimated the vegetation of disturbed ground at moorland edges and roadsides (see plates 1,9 and 10), particularly gorse.

None of these 3 major sources is satisfactory as a baseline for any future vegetation monitoring and was not designed as such. Both vegetation maps were produced subjectively and lack explicit definitions of the mapping units, so that identical mapping processes could not be repeated by other workers. The subjective sampling method of Williams' survey also means that the survey cannot be repeated in exactly the same manner.

However, these sources do contain a substantial body of information on the Exmoor moorlands. They show that the moorlands bear a great diversity of vegetation in terms of the combinations and relative abundance of the predominant species. This diversity is also clearly reflected in aerial photographs of the moors. The following species, in particular, variously predominate in different combinations and proportions: brown bent (Agrostis canina), bristle bent (A. setacea), common bent (A. tenuis), bilberry (Vaccinium myrtillus), bracken, cotton-grasses (Eriophorum angustifollum, E. vaginatum), deer-grass (Trichophorum cespitosum), dwarf furze, gorse, heather, bell heather, cross-leaved heath (Erica tetralix), heath rush (Juncus squarrosus), mat-grass (Nardus stricta), purple moor-grass, tall rushes (Juncus spp.), especially soft rush (J. effusus), sheep's fescue (Festuca ovina), Sphagnum mosses and wavy hair-grass (Deschampsia flexuosa). This great diversity in vegetation composition, although partly the result of variations in soll and drainage, largely reflects the long history of grazing on Exmoor by domestic stock. The Domesday Book 1ists many manors with extensive tracts of pasture on Exmoor, indicating that the rights of common grazing already formed an integral and necessary part of the peasant economy at the time of the Conquest (Hoskins \& Stamp 1963).

Because the vegetation categories used are different, direct comparison of the different sources is not possible. However, the categories can be merged to form only 6 main vegetation types as defined by ITE (1978), which are broadly comparable between the different sources as well as between 
regions (see Appendices 1-4). Considering the disparate origins of the data, the relative abundances of the 6 main vegetation types show a high degree of correspondence between sources.

It is interesting to compare the vegetation of the 5 different regions of Exmoor. The data in Appendices $1-4$ are set out to facilitate such comparison. For simplicity, however, the data from the different sources have been averaged to produce Figure 2.2. The data for the Brendon heaths are derived only from Sinclatr's 1965 map and Williams' partial survey of 1977-78, in which probably only about $30 \%$ of the area was sampled. They are, therefore, of doubtful correspondence with the totality of existing vegetation and must be treated with caution. The data for the other regions, however, reflect quite well the existing gross patterns of vegetation. Among these, the central grass moors are clearly characterized by a preponderance of purple moor-grass and bent/fescue grasslands, together probably covering some $80 \%$ of the ground, while the other 3 regions show a preponderance of dwarf shrub heaths. These latter regions each appear to be distinguishable by smaller, but still important, differences. The coastal heaths show a lesser preponderance of dwarf shrub heaths than the northern and southern heather moor regions, but a substantially higher proportion of bent/fescue grasslands, and probably more bracken-covered ground also. The northern heather moor region seems to have a greater proportion of dwarf shrub heaths (mainly heather) than the southern heather moors, and the latter more bent/fescue grasslands, and bracken- and gorse-covered ground. These differences are shown in more detail by analysis of Appendices 1-4. They also accord with the impressions we received during a brief reconnaissance of Exmoor.

It is useful to compare the relative diversity of moorland vegetation in the different Exmoor regions. Considered simply in terms of the different numbers of vegetation types recognized in the classifications given in Appendices 1-4 (see Table 2.4), the coastal and Brendon heaths show substantially less vegetational diversity than the other 3 regions, bearing, on average, only half the number of vegetation types. of the 3 'moors', the northern heather moor region seems the most diverse, and the grass moor region the least diverse.

Straightforward consideration of just the numbers of different vegetation types present in any area, however, presents only a limited view of diversity. Most people would also consider the relative abundance of different types as an essentlal aspect of diversity, so that, for example, an area bearing $50 \%$ cover of vegetation $A$ and $50 \%$ of vegetation $B$ would be considered to have higher diversity than an area with $99 \%$ of A and only $1 \%$ of B. One widely used index of diversity which takes relative abundance into account is that named after Shannon (Pielou 1975). Table 2.5 gives the Shannon indices of diversity for vegetation types in the different. Exmoor regions, as calculated from the data in Appendices 1-4. This Table genera1ly accords with Table 2.4 , but shows some interesting deviations. Thus, although the coastal and Brendon heath regions tend to show substantially lower diversity than the 2 heather moor regions, the central grass moors also tend to show lower diversity, with the exception of the indices calculated from the phytosociological types. This comparison suggests that, while the grass moors have a fairly low diversity in terms of the growth form and life form of the predominant species, they still have a fairly high diversity in terms of phytosociological assemblages. A further feature of interest is that the indices from all classifications show the southern heather moor region to be the most diverse, a point which will be rapidly impressed upon any careful observer in the field. 
Figure 2.2 Relative abundance of different broad vegetation types in the different regions of Exmoor (an average from the data of Sinclair (1970), Davies \& Jarman (1978) and R Williams ( innublished))
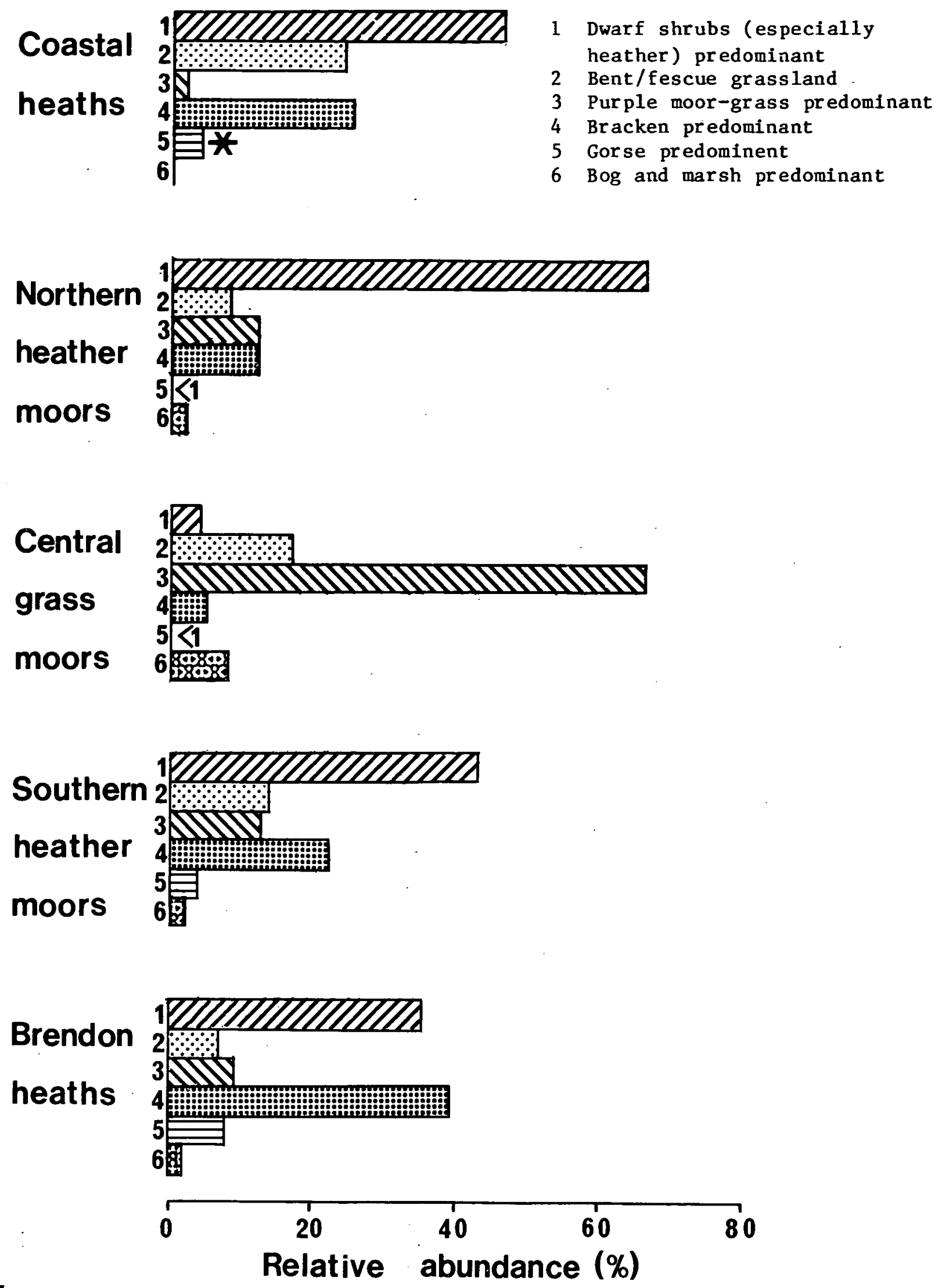

* Probably mostly dwarf furze (Ulex gallii), which should be included in type 1 (dwarf shrubs predominant). 
Table 2.4 Numbers of moorland vegetation types in the different Exmoor regions

$\begin{array}{llcc} & \text { Northern } & \text { Central } & \text { Southern } \\ \text { hoastal heather } & \text { grass } & \text { heather Brendon } \\ \text { heaths } & \text { moors } & \text { moors } & \text { moors heaths }\end{array}$

After Sinclair (1970)

(from Appendix 1);

6

10

9

9

5

maximum number $=11$

After Davies \& Jarman (1978)

(from Appendix 2);

8

12

11

20

maximum number $=23$

After W11liams; data

classified phyto-

sociologically

9

16

17

17

8

(from Appendix 3);

maximum number $=18$

After Williams; data

classified empirically

10

18

14

19

9

(from Appendix 4);

maximum number $=19$

(Mean number)

(8)

(14)

(13)

(16)

(7) 
Table 2.5 Shannon index of diversity (I) of moorland vegetation types in the different Exmoor regions (calculated from the formula $I=-\Sigma_{p_{i}} \log _{e} p_{i}$, where $p_{i}$ is the decimal proportion of each vegetation type in each region)

$\begin{array}{llll} & \text { Northern Central } & \text { Southern } \\ \text { Coastal heather } & \text { grass } & \text { heather } & \text { Brendon } \\ \text { heaths moors } & \text { moors } & \text { moors } & \text { heaths }\end{array}$

After Sinclair (1970);

calculated from

1.54

1.53

1.33

1.76

1.22

Appendix 1

After Davies \& Jarman (1978);

calculated from

1.81

1.91

1.37

2.63

Appendix 2

\begin{abstract}
After Williams;
calculated from

Append1x 3
\end{abstract}

After Williams;

calculated from

Appendix 4
1.94

2.39

1.97

2.55

1.65 


\subsubsection{Growth of the heather}

The very abundance of heather and its prominence in the diet of wild and domestic herbivores make it a key species in the economy of Exnoor and of many other upland areas of Britain. Much has been written about the burning, grazing, cutting and fertilizing of heather (see Section 5.2), yet the improper nanagement of this species for agricultural and sporting use is a notable feature of most moorlands. Recommendations about the management of heather should be based on a knowledge of its growth in relation to age.

Stands of almost pure, even-aged heather, representing different successional stages after burning, were examined at Wilmershan Common (SS 8541, altitude 400-440 m) and Brendon Common (SS 7545, altitude 380-400 m). Each stand was distinguished by the uniformity in height, density, ground coverage and growth habit of its heather plants (Plate 5). We estimated the age of the heather (by counting annual rings) and its aerial biomass (Indirectly, by the method of Miller \& Watson 1978) in a range of different stands. Figure 2.3 shows that biomass increases with age up to 22-23 years. Strictly, some other type of growth curve should be fitted to these data but the straight Iine appears adequate. These are only crude estimates of blomass. However, S B Chapman (unpublished) found 1270 and $2220 \mathrm{~g}$ per square metre by direct measurement of stands aged 7 and 20 years at Stoke Pero Common (SS 8742, altitude $450 \mathrm{~m}$ ) in 1964 , suggesting that our estimates are of the correct magnitude.

Comparisons with the biomass of heather at other moorland sites suggest that Exmoor is especially productive. The accumulated biomass 5,10 and 20 years after burning is much greater than in Dorset, northern England or north-east Scotland, and is similar only to the heather at Dartmoor (Table 2.6). The poor productivity of the heather on Dorset heathland can be explained by the particularly impoverished soils there (Miller 1979). The soils at Kerloch, in north-east Scotland, have a similar extractable nutrient content to those at Dartmoor, and therefore the superior productivity at Dartmoor and Exmoor can probably be attributed to warmer summer temperatures and a longer growing season. In this respect, it is noteworthy that young heather at $430 \mathrm{~m}$ altitude on Wilmersham Common (SS 850416) was seen with $2 \mathrm{~mm}$ of new growth at the shoot tips on 8 March 1979, fully 6-8 weeks before growth is expected at similar altitudes in northeast Scotland.

Heather may be less productive on some of the more exposed coastal heaths on Exmoor. At Holdstone Down (SS 6247) and North Hill (SS 9447), the vegetation is generally short and appears wind-clipped. Heather plants aged 10-13 years were found to be $2.7-3.4 \mathrm{~mm}$ in diameter at the base of the stem, whereas similarly aged plants at Wilmersham and Brendon Commons ranged from 5-9 $\mathrm{mm}$ in basal diameter. Nonetheless, the inild climate and mainly free-draining mineral soils at Exmoor probably sustain levels of heather productivity that are greater than on most northern moors.

\subsection{Wild animals}

2.4.1 Red deer

So far as we know, the red deer (Cervus elaphus) of Exmoor has never been studied systenatically. Such knowledge as exists about the history of the herd, the biology and size of the population is largely hearsay, and has been summarized by Whitehead (1964) and Lloyd (1975). 
Figure 2.3 Biomass of heather stands in relation to their age at

(a) Wilmersham Common (400-440 m altitude) and

(b) Brendon Common (380-400 m)

(a)

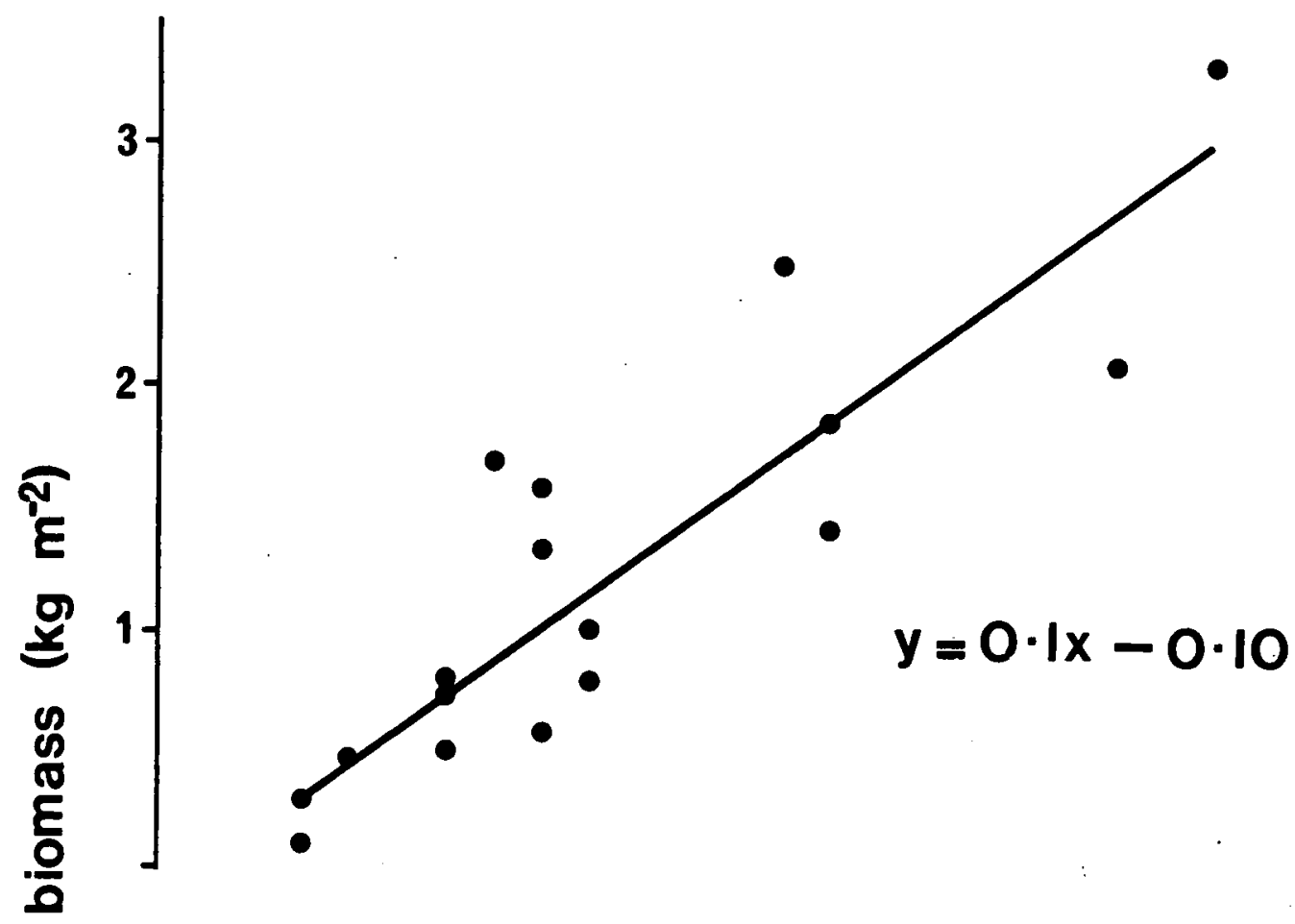

(b)

$\frac{8}{2}$
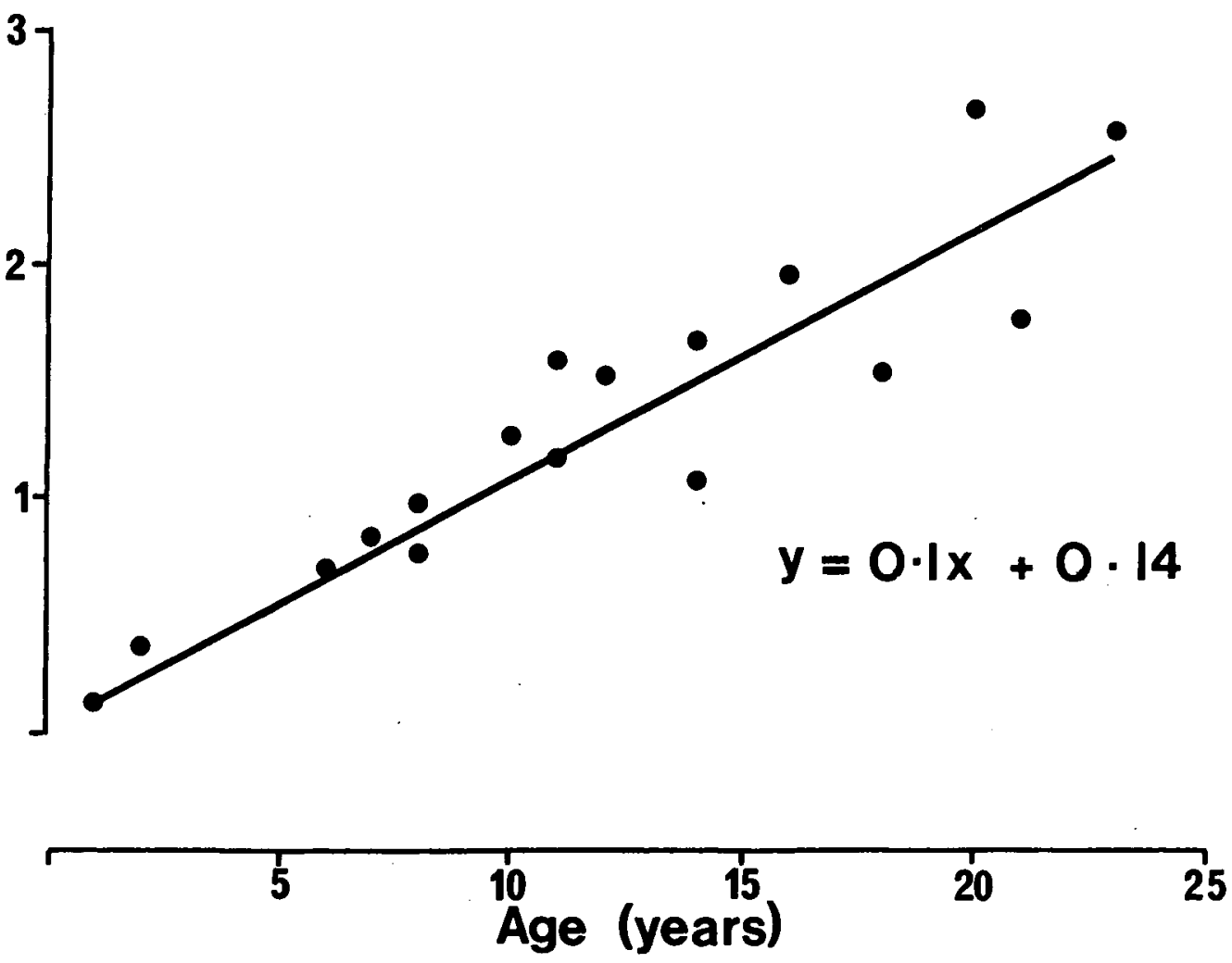
范

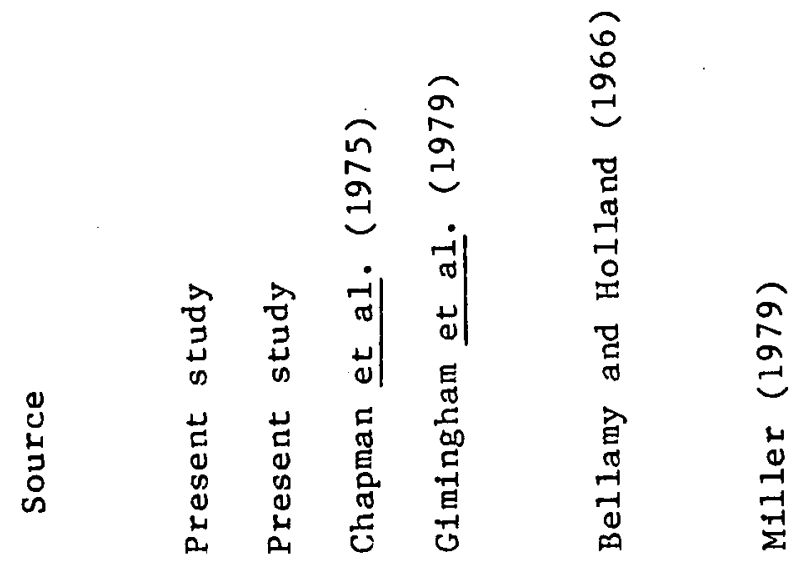

in

.

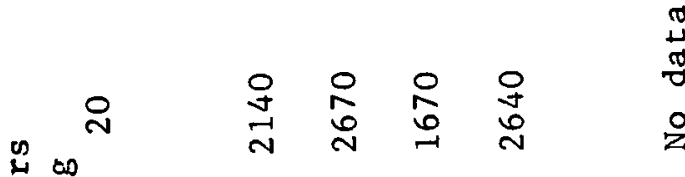

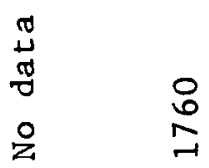

焉

¿

$>$

㟧苛只 号

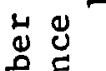

穵

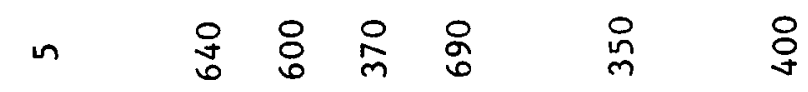

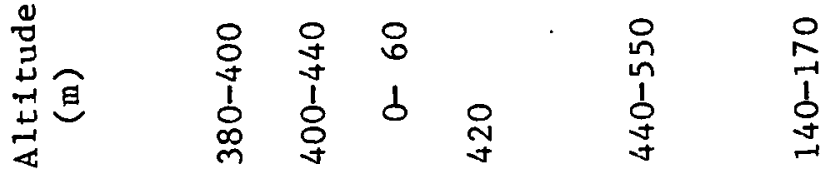

令离

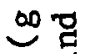

$\infty \frac{\pi}{-1}$

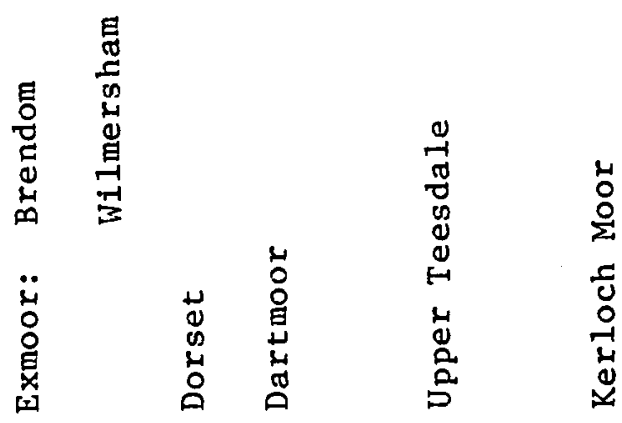

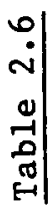

5
0
0
00
0
01

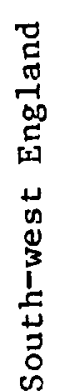

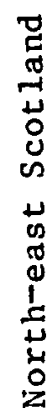


The red deer on Exmoor are feral, being the progeny of stock which escaped or was released deliberately from deer parks in the second half of the 19th century (Hamilton 1907). The fact that these deer are feral rather than of native Exmoor stock has been demonstrated by Lowe and Gardiner (1974) in a morphometric study of the various stocks of red deer at large in the British Isles and Ireland. The sample from the west country was collected by the Forestry Commission in their forest at Halwi11. The skull shapes of this sample showed that they had no affinities with the native deer. from Scotland and north-west England, but had obvious affinities with deer from parks or from other feral stocks known to be derived from park deer. This difference in skull shape between native and park deer is very marked because of the highly selective killing, which has been practised in deer parks over the centuries to produce bigger and better 'heads'. The distinction between native and feral red deer is of particular relevance to the conservation of the native fauna of Great Britain, but has negligible effect on the sporting and visual value of the Exmoor stock.

There are said to be 700-900 red deer living within the boundary of the Exmoor National Park and this is thought to be a smaller population than existed in the 1930s. The 2 main areas of concentration are in the woodlands between Dunkery $\mathrm{Hill}$ and the north coast, and in the strip of woodland in the Barle Valley between Withypool and Dulverton. Other, smaller, groupings occur throughout Exmoor.

One group of 50-60 deer is known to range habitually over some 2300 ha of grass moorland in Exmoor Forest, particularly in June-September. However, the majority are said to behave as woodland animals, seldom venturing on to open moorland, and even then only in summer. In winter, particularly, they go on to farmland, causing damage to turnips and other crops.

Living in a relatively benevolent environment, it is not surprising that red deer appear to thrive on Exmoor. Few die of starvation or, because of the activities of the hunts, of old age. Further, these deer are thought to be heavier and more prolific than Scottish beasts which live in poorer habitats. It has been said, for example, that some $90 \%$ of the adult hinds become pregnant annually and eventually rear $0.4-0.5$ calves each, compared with pregnancy rates of $60-70 \%$ and calving rates of $0.3-0.4$ in Scot land (Mitchell et al. 1977). However, these claims about Exmoor deer are hearsay and should therefore be interpreted with caution.

Clearly, the red deer on Exmoor is not an endangered species at present. Some people argue that, if hunting were to be abolished by statute, deer would be brought to extinction by farmers shooting marauders to prevent damage to crops and to woodlands. Possibly the size of the deer stock would be considerably reduced if this were to happen, but, in view of the animals' concentration in woodlands, it seems unlikely that they would be completely eliminated without determined effort.

\section{4 .2 other mammals}

Even less information is available about the other wild mammals of Exmoor. Three other species of deer occur - sika (Cervus nippon), fallow (Dama dama) and roe (Capreolus capreolus) - but they are seldom, if ever, seen on open moor land.

Brown hares (Lepus capensis) and, more commonly, rabbits (Oryctolagus cuniculus) occur around the edges of moorland. Amongst the true rodents, the wood mouse (Apodemus sylvaticus), the bank vole (Clethrionomys 
glareolus) and field vole (Microtus agrestis) are ubiquitous. These are preyed upon by foxes (Vulpes vulpes), stoats (Mustela erminea) and weasels (Mustela nivalis). The polecat (M. putorius) was once native to Exmoor but is now extinct. A closely related species, the mink (Mustela vison), has become feral and is reputedly increasing in numbers.

So far as we know, none of these or any other species of moorland mammal resident on Exmoor is scarce or in immediate danger of extinction. Otters (Lutra lutra) are known to be present, but thought to be scarce; their exact status is conjectural and deserves further study.

\section{$2 \cdot 4 \cdot 3$ Game birds}

Two species of game bird occur on Exmoor: black grouse (Lyurus tetrix) and red grouse (Lagopus 1. scoticus). Both are uncommon and numbers seem to have decreased appreciably in recent years.

The black grouse is thought to be a native of Exmoor and does not occur elsewhere in south-west England. There are said to have been 45 birds in 1964 (Allen 1976), distributed between Molland and Withypool Commons in the southern heather moor region and Wilmersham Common and Dunkery Hill in the northern heather moors. Hand-reared birds were introduced in 1969 and 1971 in an attempt to boost the population, but the recent survey of moorlands birds (Davies \& Jarman 1978) revealed only 2 cocks; hens were possibly overlooked because of their similarity to red grouse.

Records of the numbers of black grouse shot at Dunkery Hil1, North Molton Hill and Landacre over the last 50 years show large fluctuations. In most years, no birds were shot, indicating that they have never been consistently abundant in these areas. The biggest bags (up to 20 birds in one year) were in the $1920 \mathrm{~s}$ and mid-1940s at Dunkery, and in 1959-61 at North Molland and Landacre. Figures for the 1970 s confirm that stocks. have declined: only 1-2 birds shot per year at Dunkery, and, at North Molland and Landacre, no shooting at all since 1968.

The red grouse is not native to Exmoor, having been introduced to the area in the 19 th century. It appears to have become well-established in the 1920 s but, since then, its numbers have fluctuated widely. Several attempts have been made to introduce more birds from elsewhere but without any clear success. However, it is generally more common than black grouse and shooting has been much less irregular.

Grouse bags are an unreliable measure of the birds' population size. Nonetheless, in the absence of systematic counts, they probably provide at least a rough index of changes in relative abundance from year to year, especially if the number of days when shooting took place is taken into account. Post-war data from Sir Dennis Stucley's shoots at North Molton Hi11, Landacre and Brendon Common, and from the National Trust's property at Dunkery Hill, show the cycles of abundance and scarcity characteristic of most red grouse stocks (Figure 2.4). There appear to have been periods of relatively big stocks around the years 1959,1970 and 1976, possibly also in 1950-51. Conversely, stocks were probably small in the years 1956 , 1963, 1974 and 1978. Indeed, birds were so scarce at Dunkery in 1978 that there was no shooting at a11, only the second year since 1946 that this has happened.

Grouse have never been counted by methods of established accuracy on any part of Exmoor. Allen (1976) gives an estimate of 40 pairs in the main 
Figure 2.4 Average number of red grouse shot per day's shooting in 1946-78 at (a) North Molton Hill, Landacre and Brendon Common, and (b) Dunkery Hill. Gaps due to no shooting or to missing data are represented by dotted lines

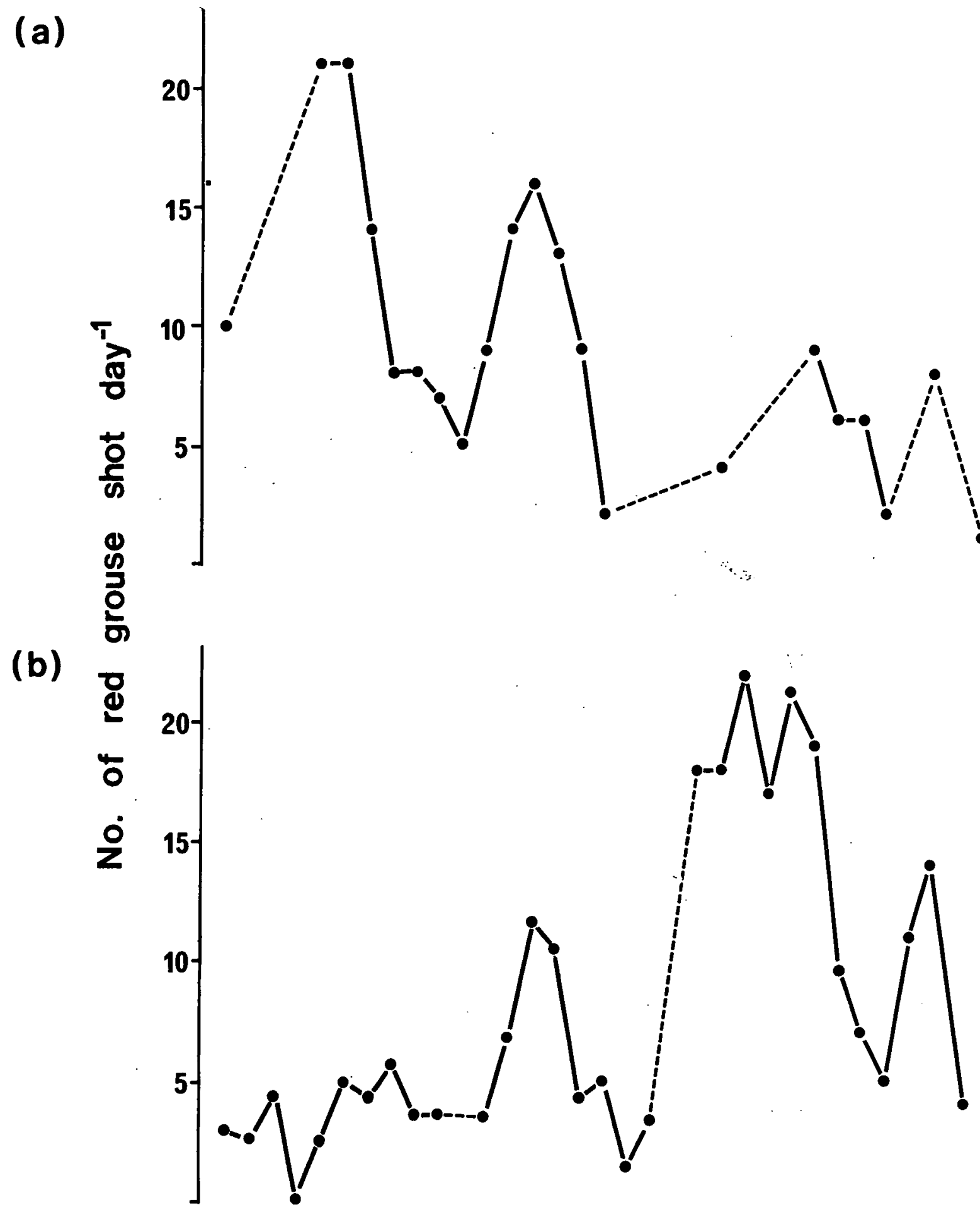


breeding area extending from the east end of Dunkery Hill (SS 9042) westwards to Weir Water (SS 8344). In 1978, grouse were sighted in 8 of the $1-\mathrm{km}$ squares in this area and in a further 6 squares elsewhere on Exmoor, ie $7 \%$ of the total (Davies \& Jarman 1978). The breeding population for all Exmoor was estimated as not more than 12 pairs. The game bag records suggest that the grouse stock will probably recover to another phase of temporary abundance so long as the birds are not, in the meantime, completely eliminated by shooting, predation or disturbance.

\subsubsection{Predatory birds}

Allen (1976) lists some 16 species of predatory bird for the moorlands of Exmoor, but only 2, the merlin (Falco columbarius) and the kestrel (F. tinnunculus), breed regularly on the moors (Table 2.7). The sparrowhawk (Accipiter nisus) and buzzard (Buteo buteo) are also regular breeders, but more characteristically in woodlands around the edge of the moor. Several species are known to have bred in past years, but no longer do so, or on1y rarely. Amongst these, the hen harrier (Circus cyaneus) and the short-eared owl (Asio flammeus) are habitual breeders on moorland. The harrier bred regularly on Exmoor up to about 1900 and perhaps a few times since, though not for many years. The ow1 has nested more recently: 2 attempted to do so in 1977, but their eggs may have been taken by collectors (Davies \& Jarman 1978). Several other species occur as casual visitors to Exmoor, and there is even one record of a golden eagle (Aquila chrysaetos) at Porlock marsh (A11en 1976).

Davies and Jarman (1978) mapped the distribution of 3 species, indicating those $1-\mathrm{km}$ squares where they were sighted during the breeding season and those where there was a strong presumption of nesting. An analysis. of their maps (Table 2.8) shows that buzzards and kestrels were seen over a wide area of Exmoor ( $47 \%$ and $37 \%$ of the $1-\mathrm{km}$ squares) and were known to breed, whereas sparrowhawks were less widespread ( $7 \%$ of the $1-\mathrm{km}$ squares) and did not breed. These 3 raptors were most common1y seen on the northern heather moors, though buzzards. also ranged widely over the central grass moors and southern heather moors, presumably in search of prey. Few records came from the coastal heaths (although kestrels were relatively common there) or from the Brendon heaths. Data for the Brendon heaths are perhaps best discounted: on 1 y $41-\mathrm{km}$ squares were recorded there owing to the patchiness and small size of the moorland areas.

At least 15-20 pairs of kestrels bred on the moors in 1978, but only on the coastal heaths and northern heather moors (Table 2.8); others bred on surrounding farmland and woodland. Davies and Jarman (1978) give no data for the number of breeding buzzards beyond stating that there was a good population; Allen (1976) suggests $80-100$ pairs, a surprisingly large figure.

Exmoor is perhaps best known as the most southerly breeding area of the merlin. No more than 4 pairs nested in 1978: but only 2 were successful in rearing a total of 10 young ( $\mathrm{N} V$ Allen, personal communication). For this reason, and because the population is so small as to be easily eliminated, information on the birds' distribution is not made public.

\subsubsection{Other moorland birds}

The best source of quantitative information about the moorland birds of Exmoor is the survey of Davies and Jarman (1978). They note that several species attain surprisingly high population denstiles. The curlew 
Table 2.7 Predatory birds of Exmoor moorlands

A. Species breeding regularly on the noor

$\begin{array}{ll}\text { Merlin } & \text { Falco columbarius } \\ \text { Kestrel } & \text { F. tinnunculus }\end{array}$

B. Species breeding regularly at the moorland edge

$\begin{array}{ll}\text { * Sparrowhawk } & \text { Accipiter nisus } \\ \text { * Buzzard } & \text { Buteo buteo }\end{array}$

C. Species breeding only rarely on or near the moor

$\begin{array}{ll}\text { Hen harrier } & \text { Circus cyaneus } \\ \text { Montague's harrier } & \text { C. pygargus } \\ \text { Peregrine } & \text { Falco peregrinus } \\ \text { Hobby } & \text { F. subbuteo } \\ \text { Short-eared ow1 } & \text { Asio flammeus }\end{array}$

D. Migratory species and occasional visitors

$\begin{array}{ll}\text { Honey buzzard } & \text { Pernis apivorus } \\ \text { Red kite } & \frac{\text { Milvus milvus }}{\text { Goshawk }} \\ \text { Rough-legged buzzard } & \text { Buteo lagopus } \\ \text { White-tailed eagle } & \text { Haliaeetus albicilla } \\ \text { Marsh harrier } & \text { Circus aeruglnosus }\end{array}$

* Distribution mapped by Davles and Jarman (1976) 
Table 2.8 Proportions (\%) of $1-\mathrm{km}$ squares in different regions of Exmoor in 1978 where certain predatory birds were

(a) sighted, and (b) thought to have bred

$\begin{array}{lcccc}\text { Northern } & \text { Central } & \text { Southern } \\ \text { Coastal } & \begin{array}{c}\text { heather } \\ \text { grass }\end{array} & \text { heather } & \text { Brendon } \\ \text { heaths } & \text { moors } & \text { moors } & \text { moors } & \text { heaths overall }\end{array}$

Number $\cdot \hat{f}$

25

79

45

49

4

202

$1-\mathrm{km}$ squares

Sparrowhawk (

(a) 4

15

2

2

0

7

(b) 0

0

0

0

0

0

Buzzard

(a) 24

55

49

49

0

47

(b) 8

3

0

2

0

2

Kestre1

(a) 44

52

16

33

25

37

(b)

4

3

0

0

0

1 
(Numenius arquata), cuckoo (Cuculus canorus), meadow pipit (Anthus pratensis) and tree pipit (A. trivialis) occur at densities similar to the national averages quoted by Sharrock (1976). However, stonechat (Saxicola torquata), whinchat ( $\mathrm{S}$. rubetra) and skylark (Alauda arvensis) are particularly numerous, having densities of more than twice the national average. Indeed, Exmoor is thought to hold about $1.5 \%$ of the total British population of whinchats.

Davies and Jarman (1978) present maps showing the presence and absence of 25 breeding species in each of the $2021-\mathrm{km}$ squares of Exmoor that contain moorland vegetation. Twenty of these species are neither game nor predatory birds and they have been grouped according to their habitat preferences in Table 2.9. Skylarks and meadow pipits were not mapped, presumably because they occur in large numbers (about 1800 birds per $10-\mathrm{km}$ square) almost everywhere, but especially on the grass moors. Of the 9 moorland species that were mapped, the lapwing (Vanellus vanellus), snipe (Gallinago gallinago), ring ouzel (Turdus torquatus) and grasshopper warbler (Locustella naevia) are notably sparse in numbers and distribution, contrasting with the abundant and widespread wheatear (Oenanthe oenanthe), stonechat and whinchat (Table 2.9). The appreciable areas of moorland colonized by gorse scrub (see Section 2.3.2) also support a characteristic avifauna, amongst which the willow warbler (Phylloscopus trochilus) and linnet (Acanthis cannabina) are prominent, as is the unmapped wren (Troglodytes troglodytes) and blackbird (Turdus merula).

Examination of the breeding distribution of the 9 mapped moorland species amongst the 4 main regions of Exmoor (Figure 2.5) indicates that, as with red grouse and kestrel, the northern heather moors may provide the greatest amount of suitable habitat. It is the only region where all 9 specles breed and 4 of them in a greater proportion of 1-kn squares than elsewhere. Stonechats, whinchats and tree pipits are all widespread on the coastal heaths and on the northern and southern moors. These species presumably thrive in the many patches and stretches of gorse and hawthorn scrub that are a feature of these regions. Conversely, gorse and bracken are scarce on the central grass moors, which may partially explain the restricted distribution of some birds there, especially the stonechat.

The surveyors' counts of the numbers of different breeding species per square kllometre emphasize the relative barrenness of the central grass moors (Table 2.10). This region, on average, supports 3.8 species per square kilometre, significantly fewer ( $P$ 0.01) than the 6.7-7.4 species per square kilometre found in the other main regions. Indeed, in 16 of the 45 $1-\mathrm{km}$ squares within the grass moors, only 2 species were recorded, the meadow pipit and the skylark. The highest count of different species on a single square was a mere 12 at Horcombe (SS 7438), whereas there were maximum counts of 21 at SS 8942 and at SS 8529 on the heather moors. Although there tend to be fewer breeding species in those $1-k m$ squares that contain high ground or have no woodland, this does not account entirely for the paucity of bird species on the grass moors.

Finally, it is worth noting that Davies and Jarman (1978) record large numbers of golden plover (Charadrius apricarius), currently a winter visitor to Exmoor, lingering on into April. Flocks of 100-150 birds were seen at Maddacombe (SS 8442) and Winsford Hill (SS 7341). As several pairs of this species now breed on Dartmoor, there is a strong possibility that it might also begin nesting on Exmoor. 
Table 2.9 Proportion (\%) of the $2021-\mathrm{km}$ squares of Exmoor moorlands in which the non-game and non-predatory bird species mapped by Davies and Jarman (1978) were (a) sighted and (b) thought to have bred, and approximate number of breeding pairs

\begin{tabular}{|c|c|}
\hline$\%$ of $1-\mathrm{km}$ & number of \\
\hline (a) (b) & pairs \\
\hline
\end{tabular}

A. Species especially characteristic of moorlands

Lapwing
Snipe
Curlew
Ring ouze1
Wheatear
Stonechat
Whinchat

Lapwing

Ring ouze1

Stonechat

Whinchat

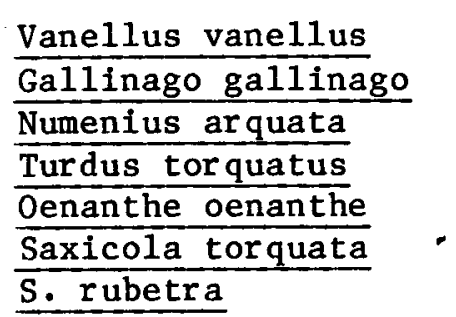

B. Other moorland species
Grasshopper warbler

Tree pipit

Locustella naevia Anthus trivialis

$\begin{array}{rr}5 & 2 \\ 6 & 5 \\ 19 & 12 \\ 9 & 7 \\ 44 & 29 \\ 49 & 47 \\ 66 & 63\end{array}$

No data 20

$30-35$

20

90-100

150

450-600

C. Species characteristic of gorse scrub

$\begin{array}{llrrr}\text { Whitethroat } & \text { Sylvia communis } & 5 & 4 & 16 \\ \text { Willow warbler } & \text { Phylloscopus trochilus } & 28 & 25 & \text { No data } \\ \text { Linnet } & \text { Acanthis cannabina } & 24 & 16 & 150 \\ \text { Yellowhammer } & \text { Emberiza citrine1la } & 8 & 8 & \text { No data }\end{array}$

D. Species characteristic of other habitats

$\begin{array}{llrrr}\text { Heron } & \text { Ardea cinerea } & 10 & 2 & 20 \\ \text { Nightjar } & \text { Caprimulgus europaeus } & 2 & 2 & 12 \\ \text { Raven } & \text { Corvus corax } & 25 & 5 & \text { No data } \\ \text { Redstart } & \text { Phoenicurus phoenicurus } & 12 & 11 & \text { No data } \\ \text { Redpol1 } & \text { Acanthis flammea } & 5 & 2 & \text { No data } \\ \text { Dipper } & \text { Cinclus cinclus } & 5 & 1 & 6 \\ \text { Grey wagtail } & \text { Motacilla cinerea } & 16 & 13 & 40\end{array}$




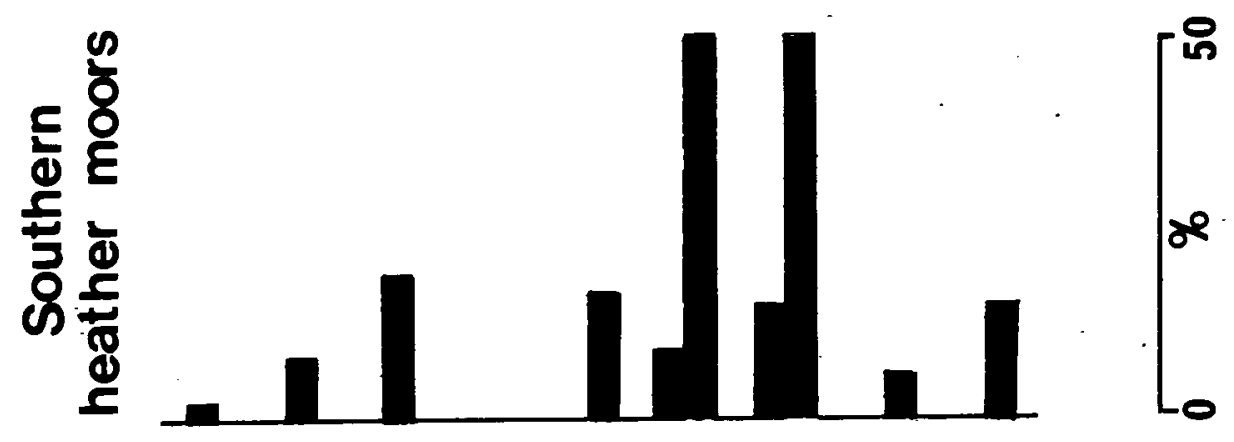

$\stackrel{\infty}{\stackrel{\sigma}{\sigma}}$

노 도

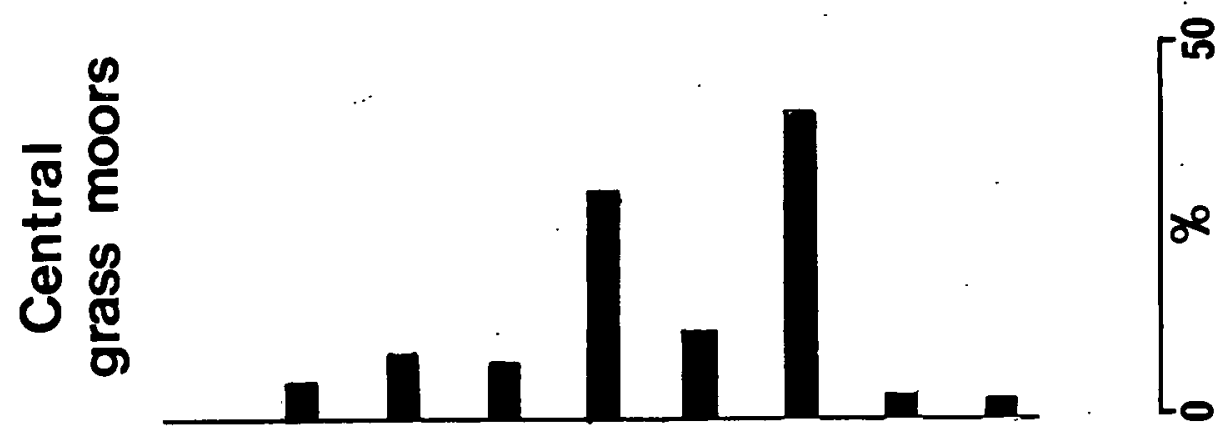

夏导

茨

苋

엉

N

岂

ป

品

出。

नु कू

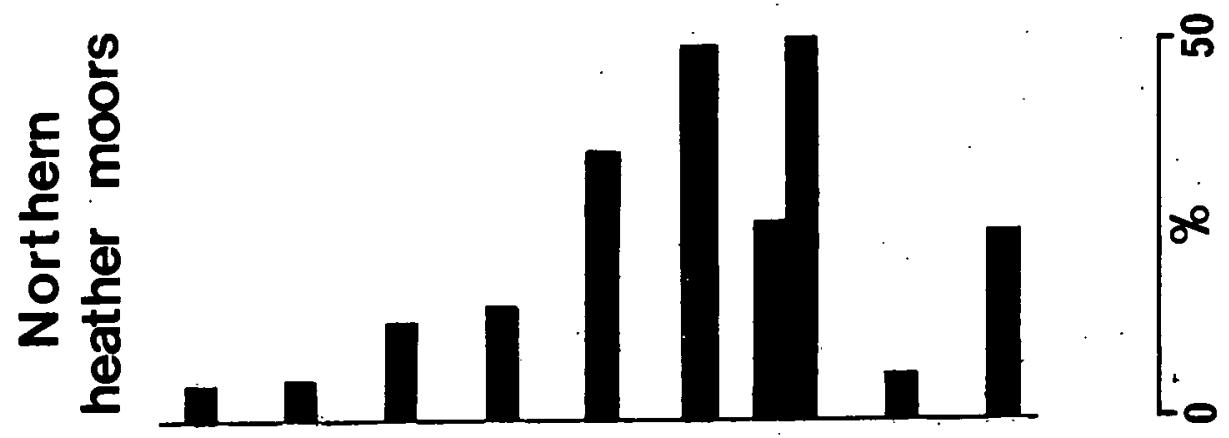

포욤

0

武

为

量递

$\rightarrow$

㟧。

ธำ ํํํ

동

어 क

i

苔

出

$n$
$\vdots$
0
$\vdots$
0
$0=1$
$0=1$

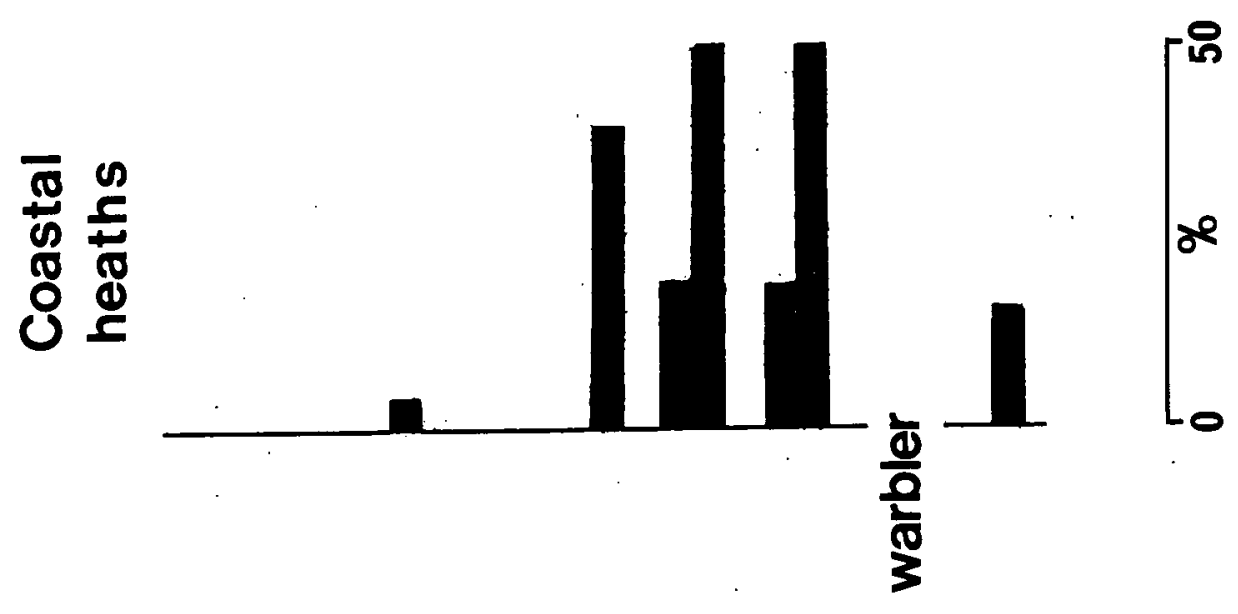

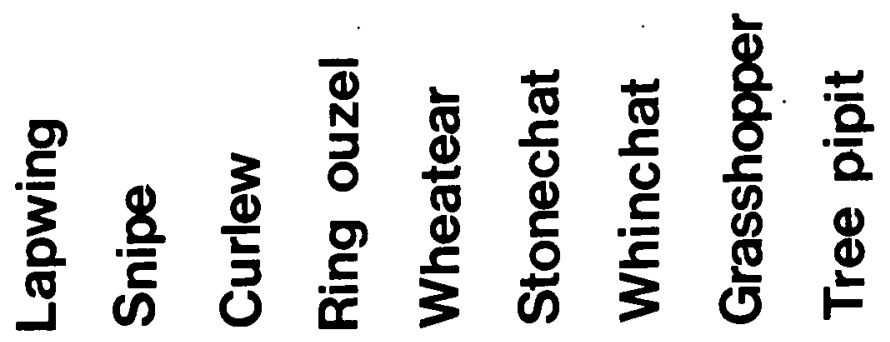


Table 2.10 Mean and standard deviation of the number of different breeding bird species per 1-km square in the different regions of Exmoor

Region

Coastal heaths

Northern heather moors

Central grass moors

Southern heather moors

Brendon heaths
Number of squares

25

79

45

49

4
3.8

2.3

6.7

4.9

3.1

4.6

5.5

1.7
Standard deviation 


\subsubsection{Reptiles and amphibians}

There was insufficient time to search for detailed information. However, the viviparous lizard (Lacerta vivipara) and adder (Vipera berus) are known to be plentiful on the moors, but the grass snake (Natrix natrix) and slow-worm (Anguis fraglils) are less common, being characteristic of low ground. The common frog (Rana temporaria) and toad (Bufo bufo) are widespread.

\subsubsection{Inver tebrates}

Linn (1970) gives a popular account of some of the more common and spectacular beetles, dragonflies and damselflies, butterflies and moths. He mentions particularly a so-called 'glacial relict', the grey mountain carpet moth (Entephria caesiata), which has a notably disjunct distribution in Britain. A comprehensive list of butterflies and moths for the $710-\mathrm{km}$ grid squares of the main moorland area has been extracted from ITE's Biological Records Centre.

These lists do not refer to specific habltats and have not been interpreted. However, they are avallable and indicate data of nature conservation interest which could be examined further. 


\subsection{Farming system}

Davies (1977) is the main source of published information about the ownership, size, cropping patterns and stocking of those Exmoor farms that incorporate appreciable amounts of moorland. The size of the farms in his survey ranged up to 883 ha of crops, grass and rough grazings. However, $77 \%$ of the 41 farms studied were less than 300 ha; the average size was 202 ha, of which area $38 \%$ was classed as rough grazings. Both sheep and beef cattle were kept, with about 5 sheep to every cow. On farms with rights of common grazing, the average stocking rate was 6.4 sheep equivalents (one cow equalling 5 sheep) per hectare of crops, grass and rough grazings, but only 4.1 sheep equivalents per hectare where there was no access to common grazing.

The size of individual holdings, the proportion of rough grazings, the ratio of sheep to cattle, and the stocking rate, all characterize these Exmoor farms as 'upland' (Jones 1978). 'Hill' farms in Wales, northern England and Scotland are generally larger and have a higher proportion of rough grazings (usually much more than $50 \%$ of the holding), fewer or no cattle, and lower stocking rates. Unlike the true hill farmer, whose stock management is geared primarily to the efficient use of his rough grazings for as much of the year as possible, most Exmoor farmers put stock on the moor in summer only. During the summer period, much of the inbye land is rested from grazing and used to produce hay, silage or root crops for winter feeding. In fact, many Exmoor farms are more or less self-sufficient in winter fodder.

The indigenous sheep is the Exmoor Horn, a fairly hardy breed that qualifies for subsidy payment. Other, hardier breeds are also used, notably Scottish Blackface, Swaledale and, particularly on the grass moors, South Country Cheviot. There has, however, been a trend for these to be replaced by 'softer', more productive breeds as the inbye and rough grazings have been improved by one means or another, and as the practice of winter housing has spread. Thus, the Devon Closewool is now the most numerous breed, with Downs, Cluns and Suffolks also prominent. Cheviots and Border Leicesters are frequently used for cross-breeding. Amongst beef cattle, the commonest breed is the Devon, but the hardier Galloway cows are grazed on the grass moors. Hereford and Friesian Cross cows are also kept on the less exposed farms with good grassland. In addition, there are pure-bred and 3 cross-bred herds of Exmoor ponies and many horses running on the moors.

In general, ewes and lambs are put out on the moor at the beginning of June and left there, apart from brief gatherings for shearing, weaning and dipping, until at least october. We have been told by farmers and MAFF officials that the stocking rate at this time is approximately 2.5 sheep per hectare. This figure accords with stocking rates quoted as the summer average for Withypool Common (Bonham-Carter 1968; Sinclair 1968). However, on certain areas, for example the common grazings on Brendon Common, the stocking rate is said to increase to 6 or 7 sheep per hectare between July and October when all the inbye land is cleared. The majority of sheep spend no more than 5-6 months of the year on moorland. Exmoor Horns may be left out for $8-9$ months but only a minority, the hardy Blackfaces and South Country Cheviots, remain on the moor for a full 12 months, and even these are taken in when heavy snow is forecast. 
Most cattle also spend only about 6 months of the year on moorland grazings, between May-June and October-November. Sometimes, particularly if the weather is mild, spring-calving cows may spend short periods on the moor in mid-winter. We saw about 20 Devons out-wintering with Exmoor ponies on Winsford Hill during the cold, wet weather of February-March 1979 (Plate 9).

\subsection{Changes in stocking rate}

From his study of 41 Exmoor farms, Davies (1977) concluded that there had been a $50 \%$ increase in the number of livestock units per hectare of crops, grass and rough grazings between 1952 and 1972. Our own analyses of the returns from parishes containing moorland vegetation show a general increase in the total number of sheep equivalents between 1947 and 1977 (Figure 3.1).

Parishes were grouped by regions (Appendix 5) to indicate possible regional differences. Over 30 years, the total number of sheep equivalents more than doubled in the coastal heath region and on the northern and southern heather moors (FIgure 3.1), equivalent to an average increase of $3-4 \%$ per annum.

Such data must be treated with extreme caution because parish returns do not distinguish between upland farms and those with no rough grazings. Thus, increases in numbers of livestock might be due mostly to changes on the lowland holdings. An analysis of the annual subsidy payments for hill sheep and cattle in each group of parishes might have yielded a more reliable index of changes in the stocking of the upland farms. MAFF were able to supply data only for the 3 years, 1976-78 (Table 3.1). During this short period, there appears to have been a tendency for stocks of hill cattle and upland sheep (receiving the basic subsidy) to decrease, but for stocks of hill sheep (higher subsidy) to increase. In terms of sheep equivalents, there was a 1-10\% decrease between 1976 and 1978 in a11 reglons but one. The exception is the southern heather moors, where the numbers of hill cattle and hill sheep both rose appreciably and the number of sheep equivalents gained $6 \%$. Records back to the late 1960s almost certainly exist, but there was insufficient time for us to trace them.

However, MAFF officials and Davies (1977) agree that there has been a substantial increase in stocking rates on upland farms since 1947 . It is also agreed that this increase has been achieved by the conversion of moorland vegetation into productive grassland, the increased use of fertilizers and of better seed mixtures on inbye grassland, and improved veterinary practices. The extent to which stocking rates have changed on the moor itself is, however, debatable.

It could be argued that any general increase in the numbers of sheep and cattle per hectare of farmland must entall greater pressures on the moor land vegetation, at least during the period of summer grazing. On the other hand, it is possible that there has been no appreciable change in grazing pressure on the moors because most of the additional stock can be carried on the improved grassland. It was even suggested to us that stocking rates on some rough grazings may have actually declined because of the farmers' introduction of softer breeds of sheep unable to thrive on a fibrous diet, and because of the growing practice of housing stock in winter: The whole question of moorland stocking rates, past, present and future, requires further study because of their effects on the direction and rate of change in the vegetation. 
Figure 3.1 Changes in total number of sheep equivalents ( 1 cow $=5$ sheep) between 1947-77 in parishes with rough grazings predominantly

in:

A - coastal heaths ( 6 parishes)

B - northern heather moors (10)

C - central grass moors (1)

D - southern heather moors (4)

E - Brendon heaths (6)

Parishes are listed in Appendix 5

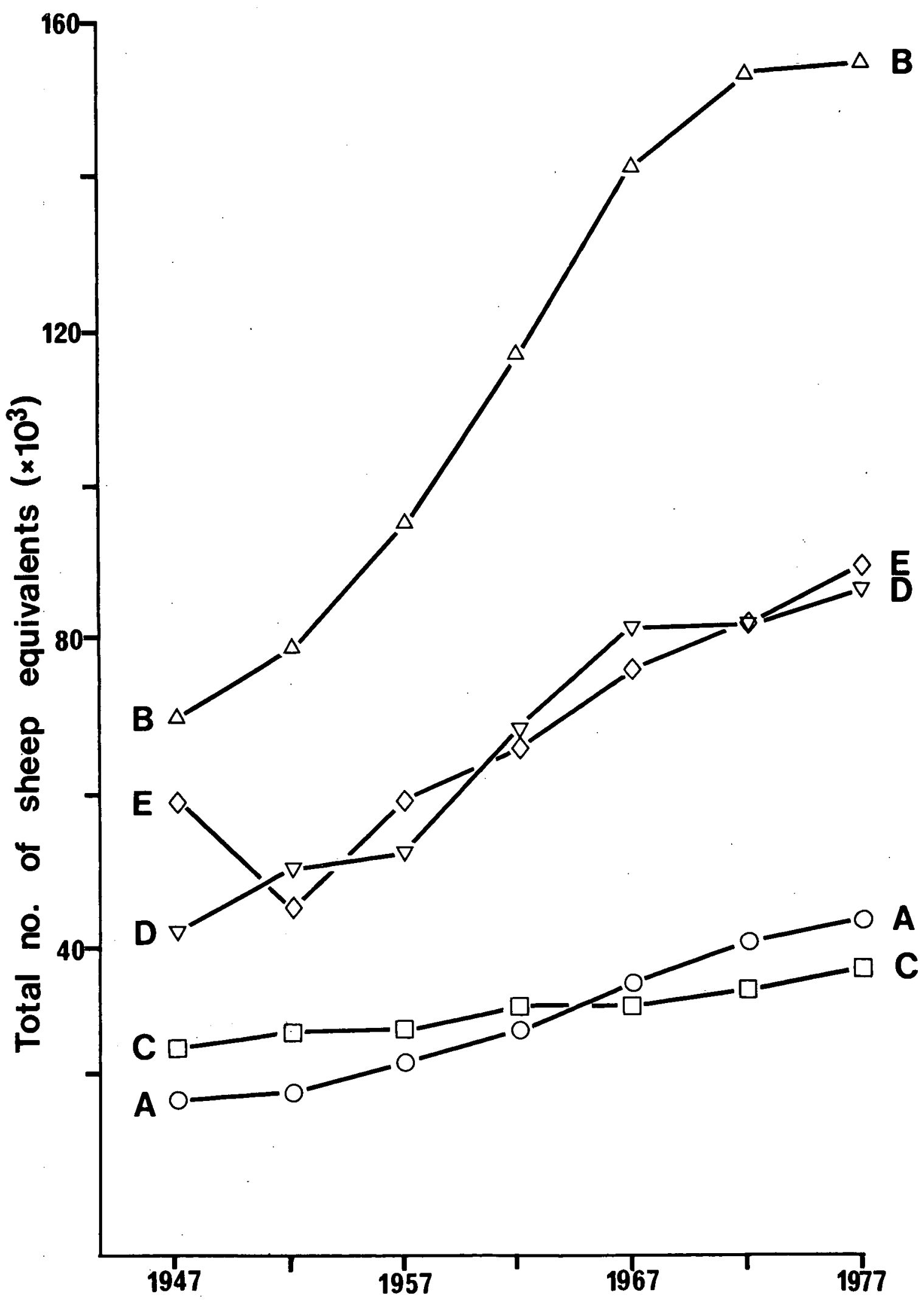


Table 3.1 Numbers of livestock in receipt of compensatory allowances in the parishes predominantly within 5 regions of Exmoor, 1976-78

$\begin{array}{llll}\text { Coastal } & \begin{array}{l}\text { Northern } \\ \text { heather }\end{array} & \begin{array}{c}\text { Central } \\ \text { grass }\end{array} & \begin{array}{c}\text { Southern } \\ \text { heather Brendon }\end{array} \\ \text { Years heaths moors } & \text { moors } & \text { moors heaths }\end{array}$

Number of parishes

6

10

1

4

6

$\begin{array}{lllllll}\text { (a) Hill cattle } & 1976 & 920 & 3586 & 791 & 2100 & 2487 \\ & 1977 & 814 & 3405 & 817 & 2047 & 2282 \\ & 1978 & 773 & 3225 & 788 & 2320 & 2006\end{array}$

$\begin{array}{rllllll}\text { (b) Upland sheep } & 1976 & 6262 & 18385 & 1253 & 13820 & 14881 \\ \text { (basic rate) } & 1977 & 6265 & 17621 & 1353 & 13743 & 14386 \\ & 1978 & 6527 & 17599 & 1316 & 13673 & 14398\end{array}$

$\begin{array}{cllllll}\text { (c) Hi11 sheep } & 1976 & 4580 & 25388 & 7219 & 8662 & 238 \\ \text { (h1gher rate) } & 1977 & 4212 & 25828 & 6992 & 8748 & 393 \\ & 1978 & 4538 & 25576 & 7083 & 9533 & 397\end{array}$




\subsection{Nutritive value of the vegetation to ruminants}

Dietary selection by ruminant herbivores is influenced by many factors, including not only the physical and chemical properties of the plant material, but also the animal's characteristics and features of its physical environment. No one factor has been shown to have an over-riding effect (Arnold 1964). On the other hand, there is a high correlation between an animal's voluntary intake of herbage (which determines its intake of energy and nutrients) and the digestibility of that herbage. Therefore, the nutritional value of plant material is generally thought to be reflected by its digestibility. This discussion of the nutritive value of vegetation on Exmoor is necessarily based on studies of digestibility elsewhere in Britain.

Some estimates of the digestibility of common moorland species are summarized in Table 3.2. All the data relate to sheep, the in vivo figures being obtained from caged animals and the in vitro by using their rumen liquor. Clearly, it is dangerous to draw firm conclusions by comparing data obtained at different times, in different places, with different materials, and even using different methods. Nevertheless, certain broad trends can be distinguished.

1. There is a notable seasonal variation which is apparently common to all species. Digestibilities are generally highest in spring and summer, the period of most rapid plant growth. They become lower after flowering, and are lowest in winter.

11. The grasses are generally much more digestible than heather: this is particularly obvious during the spring-summer period, less so in winter.

11i. Amongst grass species, the bents and fescues are more digestible than either purple moor-grass or mat-grass.

The relative decline in the digestibility of grasses during winter reflects their seasonal dieback and the consequent accumulation of dead material in the sward. Thus, Miller (1971) found that the biomass of green material in a bent/fescue hill pasture decreased from a maximum of $160 \mathrm{~g}$ per $\mathrm{m}^{2}$ in July to about $30 \mathrm{~g}$ per $\mathrm{m}^{2}$ in March. The small quantity of green material that remains in a bent/fescue sward through winter usually comprises mainly the fine-leaved grasses - red fescue (Festuca rubra) and sheep's fescue. Of these 2 species, sheep's fescue is by far the commoner on Exmoor, but we were unable to trace many figures for its digestibility. However, seasonal digestibilities of samples containing sheep's fescue mixed with common bent-grass are given in Table 3.2. Red fescue is generally considered to be superior to sheep's fescue in its feeding value, but doubtless both species will show the same relative variation in digestibility over a year. In Table 3.2, the absence of winter data for mat-grass and purple moor-grass reflects the fact that the former dies back to a great extent and the latter is completely deciduous. Heather, on the other hand, usually remains green over winter and so its seasonal decline in digestibility is not so great. Early work (Thomas \& Smith 1954; Smith \& Thomas 1956) suggested that heather was more digestible to sheep during the first 7 years after burning than was older material. Although Milne (1974) also found significant differences between stands of different ages, the age of his youngest stand was not determined accurately.

These measurements of digestibility generally correlate with the observed grazing preferences of hill sheep (Macleod 1955; Hunter 1962; Martin 1964; 
Grant et al. 1976). Grasses are taken mainly in spring and summer. If available, bent/fescue grassland is grazed throughout the year, whereas the grazing of purple moor-grass and mat-grass is confined mainly to spring and early summer. Although the digestibility of heather is also highest in spring and summer, it is nonetheless inferior to that of all the grasses. In fact, heather is not eaten much at this time. However, as the season advances, the gap between the digestibilities of heather and grass narrows. By winter, the nutritive value of heather is as good as, if not better than, that of the surviving grasses and it becomes a major dietary component.

The digestibility of any single plant species can be influenced by other components of the diet. For example, sheep are able to digest a mixture of heather and hay better than might be expected from the individual digestibilities of the components (Armstrong \& Thomas 1953). Any discussion about the probable nutritive value of different vegetation types is therefore speculative because of the possible effect of interactions amongst component plant species upon overall digestibility. However, consideration of the data in Table 3.2 suggests that the bent/fescue grasslands of Exmoor are probably of greatest nutritive value to herbivores, especially from the beginning of the growing season unt11 late summer. Apart from the coastal heaths, these grasslands are only a minor component of the vegetation of the regions. Communities with purple moor-grass predominant, but often containing a substantial proportion of bents, fescues and other grasses, are more widespread, especially on the grass moors, and will probably provide good nutrition during early summer. From about July onwards, they will decline in quality, particularly if there is only a small proportion of other grass species or if the grazing is insufficlent to prevent flowering. In winter, when the leaves of purple moor-grass have died back completely, these grasslands will be of little grazing value unless they contain significant amounts of fescue or of other winter-green grasses such as sweet vernal-grass (Anthoxanthum odoratum). Heather itself is probably of little value during summer when so much grass is available. However, on Exmoor most heather-dominant vegetation is quite grassy and herbivores may well consume mixtures of grass and heather. In winter, when many grass species are no longer wholly green, heather alone may provide superior nutrition to that found on the grasslands.

Little can be sald about the several other major constituents of Exmoor vegetation. Bracken itself is, of course, nutritionally quite worthless throughout the year, although the vegetation under its canopy (often predominantly grass) may be of considerable value. We saw plenty of evidence that gorse is browsed, sometimes heavily; it is much eaten by Exmoor ponies ( $S$ Gates, personal communication), but no doubt cattle and sheep also take some. Nothing is known about its nutritive value. Likewise, there is no information avallable about the digestibility of bristle bent. Ecologically, it appears to fill a niche occupied elsewhere by wavy hair-grass, but it may lack the winter greenness of the hair-grass: most of the bristle bent we saw in February-March 1979 had died back to much the same extent as mat-grass. It might thus have a similarly poor nutritive value during winter.

\subsection{Conversion of moorland}

The technical procedures used to replace semi-natural moorland vegetation with seeded grassland are well known and, in any case, are beyond the 


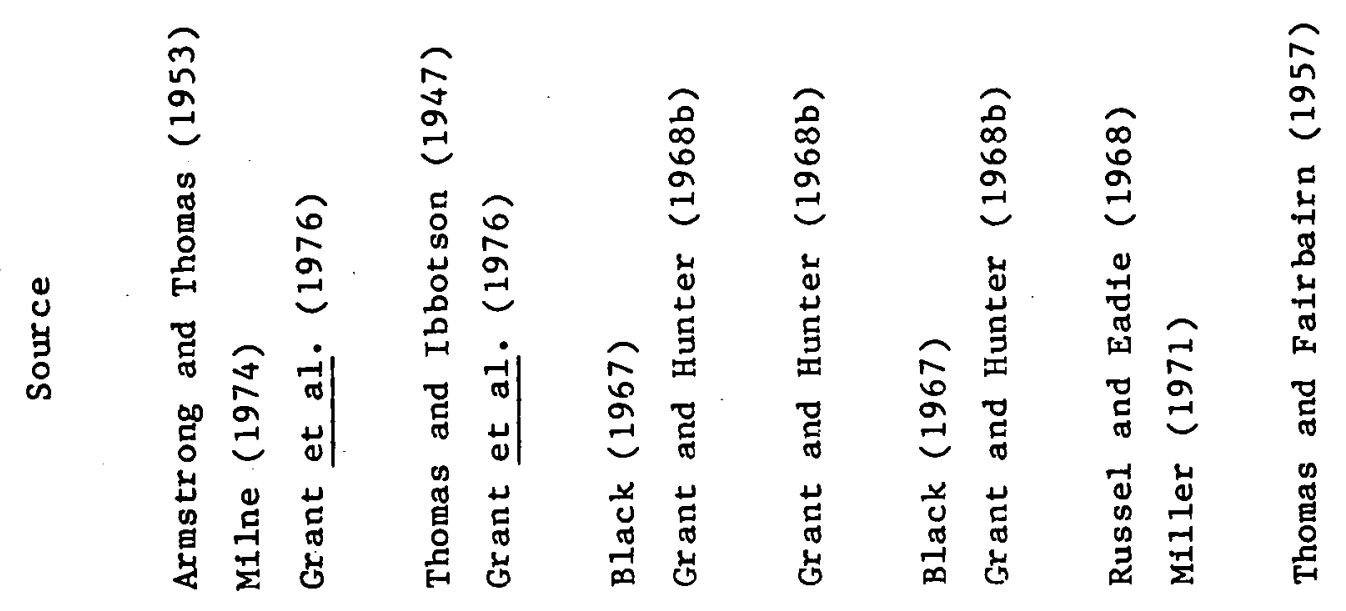

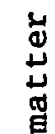

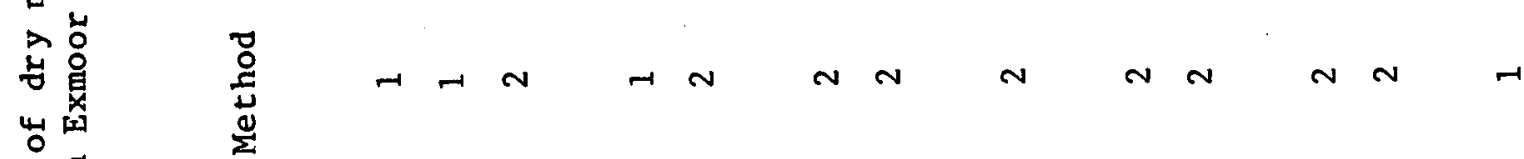

$>5$

i़

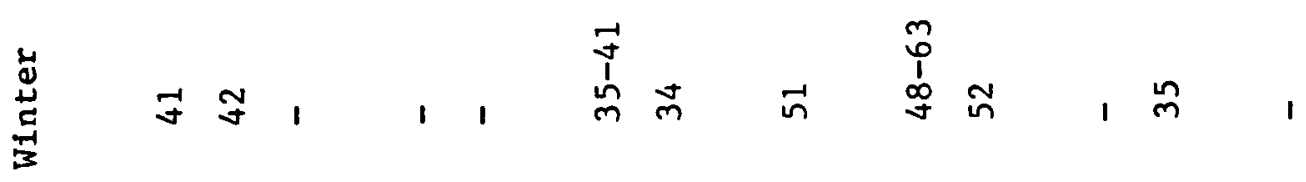
क

깅

峦

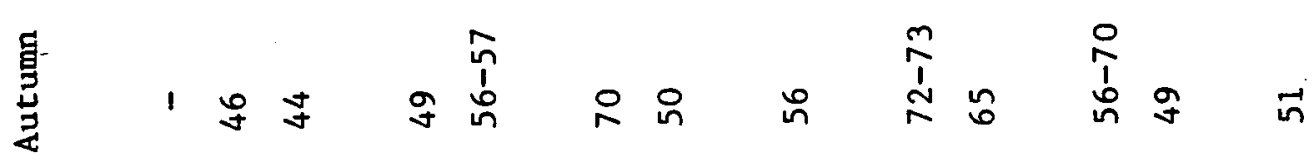
飠

in

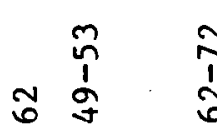

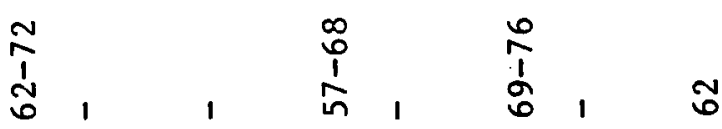

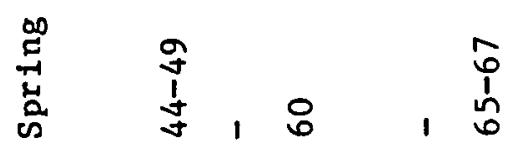

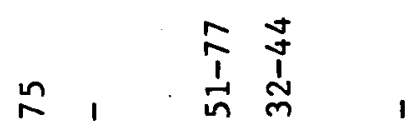

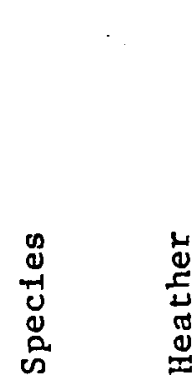

0
0
0
0
0
1
0
0
0
0
0
01
0
3
3
0

0
0
0
0
0
1
5
0
0
0
0
E
0

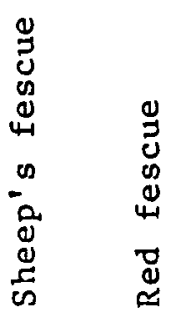

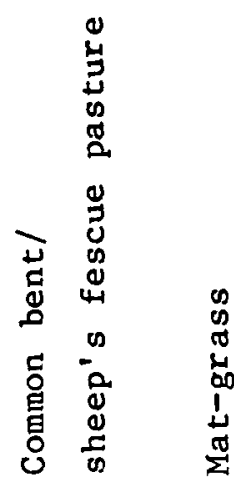


scope of this report. The nature of the land form and soils at Exmoor is such that much of the land is capable of conversion. This fact, in conjunction with economic pressures and the availability of grant aid, has encouraged farmers to plough, lime, fertilize and seed substantial areas. The economic benefits are considerable, particularly on holdings with only a small proportion of inbye grazing land. We have been told that moorland former ly supporting 2-3 ewes per hectare can take up to 15 ewes per hectare after conversion. The number of lambs produced per ewe also increases, from perhaps fewer than one up to about 1.5, so that production per hectare may rise from 2 to 22 lambs.

Porchester (1977) has calculated the average rate of moorland conversion between 1947 and 1976 as 128 ha per annum. We have been told that the rate has now decreased to 40-60 ha per year because there is less economic incentive to improve moorland grazings. Davies' (1977) study of improvements to 955 ha of rough grazings on 22 Exmoor farms between 1947 and 1976 does not suggest any decrease in recent years: the average annual rates of conversion were 20 ha in 1947-49, 26 ha in 1950-65 and 44 ha in 1966-76. MAFF supplied records for improvements to moorland vegetation between 1966 and 1976, which show that (i) most conversions were in the northern heather moors, (ii) the rate of conversion was 15-30 ha per annum in 1966-74, but (iii) this rate increased to 149 ha in 1975 and to 303 ha in 1976.

It has been estimated that there were 23800 ha of moorland on Exmoor in 1947 and that about $16 \%$ of this area had been improved up to 1976 (Porchester 1977). By using a gridded overlay on Porchester's Map C, we have estimated the proportions of moorland ploughed or otherwise improved in each of the 5 regions between 1947 and 1976 (Table 3.3). The greatest proportional loss of moorland, $38 \%$, was on the Brendon heaths, which is not surprising in view of their drier climate and better soils. Conversely, the relatively wet climate and peaty soils of the central grass moors may have restricted the loss there to about $10 \%$.

Potential losses are perhaps of greater interest. Porchester (1977) estimated that about $60 \%$ of all remaining moorland on Exmoor could be converted to seeded grassland, and Davies found that $40 \%$ of 3177 ha of enclosed rough grazings on 22 farms was improvable. Table 3.4 suggests that the main regions of potential moorland. loss are the northern and southern heather moors. The scope for converting moorland to seeded grassland is much more restricted elsewhere. On the coastal heaths, the amount of improvable land has always been limited by gradient and by stony soils, while the high rainfall and, to a lesser extent, the peat has inhibited improvement of the grass moors. In the case of the Brendon heaths, it seems that large amounts of moorland have been converted in years past and only the less accessible areas remain.

Porchester (1977) concluded that only about $30 \%$ of the moorland designated 'Critical Amenity Area' was at risk because so much of the land was owned by local authorities and the National Trust, or subject to rights of common grazing. It has not been possible to take account of this constraint in compiling Table 3.4, although substantial parts of the 2 heather moor regions are common grazings (Winsford Hill, Withypool Common, Brendon Common) or owned by the National Trust (Dunkery Hill), and therefore unlikely to be improved. 
Table 3.3 Proportions (\%) of moorland in different regions of Exmoor that were improved between 1947 and 1976, based on an analysis of Map C in Porchester (1977)

Percentage of moorland

improved in 1947-76

Coastal heaths

Northern heather moors

14

Central grass moors

Southern heather moors

Brendon heaths 
Table 3.4 Proportions (\%) of moorland in different regions of Exmoor in 1976 that are capable of improvement, based on an analysis of Map D in Porchester (1977)

$\begin{array}{ccc} & \% \text { where } & \% \text { not } \\ \text { \% capable } & \text { improvement } & \text { amenable } \\ \text { of } & \text { is limited } & \text { to } \\ \text { improvement } & \text { by topography } & \text { improvement }\end{array}$

Coastal heaths

Northern heather moors

Central grass moors

Southern heather moors

Brendon heaths
20

41

26

59

$59 \quad 16$

24

20

18

30

30

26

48

36

62

30 8 4 4

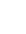




\subsection{Burning}

\subsubsection{Heather moors}

On most heather moors, the annual consumption of heather shoots by herbivores is much less than the amount produced annually by the plants. The excess production accumulates year-by-year as wood, dead shoots attached to the plants, and litter on the ground. The heather is therefore burned periodically to remove the old woody stems and litter. Burning usually encourages the sprouting of new growth which is considered beneficial to livestock, especially sheep and red grouse. When practised correctly, heather burning is strictly controlled: the area to be burned is carefully chosen according to the height, density and age of the heather plants and the fire may be attended by $2-3$ people to ensure that the flames are extinguished as soon as the desired result has been achieved. The princlples and practice of heather burning are discussed more fully in Section 5, but most handbooks (eg Muirburn Working Party 1977) agree that both planning and control are needed to get the best results.

Heathery vegetation is burned periodically on Exmoor, as it is elsewhere in Britain. There is, however, little evidence that the fires are properly planned or controlled. Discussions with people who live and work on Exmoor, and our own reconnaissance of the heather moors suggest that much of the burning is haphazard and indiscriminate. The photographs taken by Meridian Alrways during their 1976 aerial survey reveal several cases where tens of hectares have been consumed by a single blaze or by several adjacent fires. For example, a stretch of some 40 ha was burned on the south-west slope of Dunkery Hill (SS 8841) in the early 1970s. Other areas showing evidence of large (more than 50 ha), probably uncontrolled, fires or of severe burning include Shilstone Hill (SS 7646), Mill Hill (SS 8244), Wilmersham Common (SS 8642), Joany How (SS 9143), Withypool Hill (SS 8334) and Winsford Hill (SS 8734).

There are several reasons why most heather burning on Exmoor may be unplanned and uncontrolled.

i. Many burnt areas are close to public roads and at least some fires are caused by picnickers. Winsford Hill (SS 8734) and North Hill (SS 9347) seem to be particularly at risk in this respect.

11. The statutory burning season of 5 months, 1 November-31 March, includes the 3 wettest months of the year - November, December and January (Table 2.1). The wet climate may engender an opportunistic approach to burning whereby farmers are deterred from planning ahead and burn whenever and wherever they can.

iii. Davies (1977) found that the average farm of 202 ha included only 77 ha of rough grazing, indicating that most moorland is divided into small allotments owned by independent farmers. Many of the large unfenced areas, such as Brendon and Withypool Commons, are subject to rights of common grazing. Thus, there are almost no tracts of moor under exclusive management and so there is little incentive to form gangs of heather burners comprising gamekeepers and tenant farmers, as on the large Scottish estates.

iv. Many Exmoor farmers apparently do not value heather as highly as hill farmers elsewhere. In Scotland and northern England, heather is often regarded as a valuable source of winter grazing for sheep. 
Most Exmoor livestock are, in fact, taken off the moor during the winter, and in spring and summer the moorland grasses may be the preferred diet.

v. In northern Britain, controlled heather burning is of ten associated with a strong interest in shooting red grouse. There are a few grouse on Exmoor and the traditional field sports, stag hunting and fox hunting, do not require careful management of the moorland vegetation.

There are regional differences in the amount and stature of the heather on Exmoor (Table 3.5) which can be attributed to local variations in climate, grazing pressure and frequency of burning. The 2 heather moor regions have the highest proportions of heathery vegetation and also the tallest heather (more than two-thirds $1 \mathrm{~s}$ taller than $15 \mathrm{~cm}$ and, in the south, nearly one quarter is over $30 \mathrm{~cm}$ ). By implication, burning may be less frequent there than elsewhere. The low-growing heather at the coast may result from a combination of exposure to wind and frequent, uncontrolled fires. However, the shortness of the small amount of heather on the grass moors is almost certainly due to the nature of the burning management.

\subsubsection{Grass moors}

Unlike other parts of Exmoor, a large block of the grass moors is managed by one owner. The 1977 parish returns record 3768 ha of rough grazings in Exmoor Forest, of which approximately 2400 ha (about $65 \%$ ) is in single ownership.

The sole ownership of such a large area of moorland requires that there should be a coherent burning policy and that it should be put into effect. In this respect, it is noteworthy that Fortescue Estate regularly applies for an extension of the burning season until 15 April, as an insurance against bad weather. The burning policy is quite simple - each spring all the dead grass left over from the previous summer's growth is burned off. The removal of litter allows access by livestock to the new flush of grass growth, particularly valued during the lambing season in Apr 11 and May. 
Table 3.5 Amount of vegetation containing heather in 4 regions of Exmoor and proportion of heather in different height classes, based on an analysis of the maps of Davies and Jarman (1978)

$\begin{array}{clc}\text { Total } & \begin{array}{l}\text { Proportion } \\ \text { of veget- Proportion (\%) of heather } \\ \text { in different }\end{array} \\ \text { vegetation } & \begin{array}{l}\text { ation with } \\ \text { mapped }\left(\mathrm{km}^{2}\right)\end{array} & \text { heather }(\%)<15 \mathrm{~cm} \quad 15-30 \mathrm{~cm}>30 \mathrm{~cm}\end{array}$

Coastal heaths

Northern heather moors

Central grass moors

Southern heather moors
9

63

42

38

62

32

46

23 
The main non-agricultural use of the moorland is in terms of landscape, nature conservation and a wide range of recreational activities. Exmoor is accessible to densely populated parts of Britain, and the moorland attracts people, travelling mainly by car, with a particular wish to 'explore quiet areas'. The main moorland areas can be ranked in descending order of popularity as follows: Winsford Hill, Landacre, North Hill, Brendon Common, Holdstone Down, Withypool Common, Porlock Common/Porlock Hill, Haddon Hill, Anstey Common and Molland Common. The extent to which visitors to these areas actually go on to the moor, as opposed to experiencing it from the road or car park, has not been measured. However, it is probable that their major influence is on the moorland edge adjacent to roads and parking areas. Access to the moor is virtually unrestricted, and the network of footpaths and bridle-paths is used by walkers. The effect of this informal recreation on the moorland vegetation is very limited, partly because the numbers are still within the 'carrying capacity' of the moor and people remain, to a large extent, on the paths. Increasing numbers of visitors may be expected and some areas, such as Dunkery Hill and Winsford Hill, are beginning to show localized disturbance of vegetation and soil which will require management.

Pony trekking is an increasing use of the moorland, but activity is largely restricted to the $450 \mathrm{~km}$ of existing bridle-paths. Winsford Hill is very heavily used. Molland and Anstey Commons are also much used for trekking and there are several trekking centres within easy reach of Dunkery, which is consequently also used for this purpose. Exford is an important centre for riders and the trekking largely extends over the west side of Dunkery and on to Exford Common.

Environmental education is an increasing use of the moorland, with several Field Centres, mainly in the Exmoor Forest area, and with participation by the Park staff in leading youth and school groups, particularly on walks in the Dunkery area. Educational use has no obvious effect on the moorland but more intensive uses, such as hang-gliding on North Hill and motorbike scrambling on Haddon Hill, can cause localized severe damage to vegetation and soil.

The wildlife of the moorland (described in Sections 2.3 and 2.4) is an important resource, of interest to naturalists and to the Nature Conservancy Council. Wildlife is also an important part of the attraction of the area, and its conservation is thus within the interest of the National Park Authority. The nature conservation interest lies in the range of communities and the relatively large areas without intensive land use, rather than in particular rare species or communities. As a land use on Exmoor, nature conservation tends to act indirectly by influencing the type and distribution of management practices applied by other users.

Field sports are a major non-agricultural use of the moorland. The Devon and Somerset Staghounds, active since 1855, hunt red deer 3-4 times per week from early August until the end of April, with a break from 26 october to 5 November. Their activities are described by Lloyd (1975). Mature stags (more than 5 years old) are hunted from August to October, and younger stags ( $1-3$ years old) in March-April; hinds are taken from November to February. About 100 deer are kflled annually by the Devon and Somerset Staghounds ( 65 stags and 35 hinds). Another 100 are killed from the same population by the Tiverton and Quantock Staghounds. Killing is selective 
and few deer are allowed to die from old age. About 20 additional deer, mainly hinds, are shot on farms where damage cannot be controlled by hunting alone. Thus, the total kill is about 200 animals per year.

Fox hunting is also popular on Exmoor. Five resident packs are active: Exmoor Foxhounds, Dulverton East Foxhounds, Dulverton West Foxhounds, West Somerset Foxhounds, and Minehead Harriers. All encroach on to moorland to varying degrees. Each pack is active 2-3 days per week from mid-August until the end of April. Hunting is therefore a very important recreational activity on Exmoor: staghounds and foxhounds together provide 15 or more hunt-days each week from late summer until spring.

Both black and red grouse are shot, chiefly on Dunkery Hill (SS 8941) and Brendon Common (SS 7644) on the northern heather moors, and on North Molton Ridge (SS 7732) and Withypool Hill (SS 8334) on the southern heather moors. There are too few grouse for them to be driven over shooters concealed in butts, as in Scotland; instead, the birds are killed as they are: flushed, by shooting parties walking over the moor. At Dunkery Hill in the 1950s, there were 5-8 days of grouse shooting that produced 20-70 kills per year; recently, it has been worth shooting on only one day per year and the bag has not exceeded 20 birds since 1971. Shooting on the other areas has usually been confined to one or 2 days each year, and has never yielded a bag of more than 10 grouse since 1968. Grouse shooting thus commands much less active support than hunting, and is not nearly as powerful an influence on moorland use and management as it is in scotland and northern England. 
The purpose of this section is to summarize certain aspects of the biology of heather which are relevant to management, and to discuss briefly various ways that the heather on Exmoor might be maintained in a vigorous and productive condition, whether for grouse, sheep or landscape value.

\subsection{Biology of heather}

\subsubsection{Phases of the life cycle}

During their life span, heather plants change gradually in size, morphology and growth habit as they undergo physiological ageing and become less vigorous. Four distinct phases are usually recognized.

1. The earliest is the 'pioneer' phase, when young plants establish from seed or new shoots sprout from buds at the base of the charred stems remaining after a fire. During this period, plants are discrete, less than $15 \mathrm{~cm}$ tall, cover the ground incompletely, and have a higher concentration of nutrients (especially nitrogen and phosphorus) in their shoots than they do in subsequent phases.

11. Plants next pass into a 'building' phase, when they grow vigorously, become finely branched, develop a dense canopy of bright green shoots, and may cone to cover the ground so completely that almost all other vascular species disappear. At this stage, plants are up to about $30 \mathrm{~cm}$ tall and there is a very high density of stems rooting at ground level - sometimes 2000 or more per square metre.

iii. Vigour is much reduced in the 'mature' phase. Plants become 'leggy' with long thick stems and in the canopy there is much more inedible woody material than green shoots. The plants tend to be top heavy and the branches begin to fall outwards so that height does not usually exceed $40-50 \mathrm{~cm}$. Owing to the death of some stems as others thicken, density-declines to less than 1000 stems per square metre in this phase.

iv. Finally, plants become 'degenerate'. By this stage, the central branches are often prostrate and dying. There may now be less than 250 stems per square inetre, and plant height is usually less than $40 \mathrm{~cm}$. Sometimes the outer branches may layer (ie root adventitiously where they touch the ground), in which case they continue growing with renewed vigour.

There are no set ages at which heather passes from one phase to the next. Physiological ageing depends on the plant's rate of net growth, ie annual production by the plant less annual consumption by herbivores. Where net growth is slow, due to a cold climate, poor soil or heavy grazing, physiological ageing is retarded and plants may take 40 years or more to attain the degenerate phase. Conversely, rapid net growth entails rapid ageing and degeneracy may be reached in less than 20 years. Our sampling of the heather at 2 Exmoor sites (Section 2.3.3) indicates that net growth was rapid. Indeed, one 13 year old stand of heather was classed as degenerate, though most degenerate heather was 20-23 years old. 


\subsubsection{Regeneration after fire}

Burnt heather can regenerate either from seed or from the sprouting of buds at the base of stems left by the fire. Often, both methods of regeneration contribute to the heather's recovery.

Large numbers of smal1, light seeds are shed annually, up to one million per square metre in a good year. Most seeds are viable, but, in a growing heather stand, conditions are rarely suitable for germination and establishment. However, some seeds become buried in the litter and soil and can remain viable for many years. Well over 50000 buried viable seeds per square metre may be present. After a fire, seedling establishment may come both from these buried seeds, and from any that are shed on to the burnt area. Establishment from seeds is usually erratic, many seedlings succumbing to drought unless they are on a compacted moist peaty surface. Furthermore, initial growth is very slow because there are few food reserves in seeds weighing, on average, about $0.04 \mathrm{mg}$ each.

On the other hand, shoots sprouting from the base of a stem benefit from the parent's root system and underground reserves of food. Growth is therefore usually rapid, and complete coverage of the ground may be restored within 3 years of burning, very much faster than from seed alone. Rapid regeneration of heather after burning is obviously desirable, and it clearly depends on the extent of vegetative sprouting from the base of heather stems.

Five different factors influence vegetative sprouting, and 4 of them can be under at least partial human control.

1. Foremost is the physiological age of the plants at the time of burning. A11 stems rooted at ground level are potential sources of new growth after fire. Therefore, successful regeneration is most likely when heather is burned at the building phase of its life cycle. Later phases have less regenerative potential because of a decrease in the density of rooted stems (Miller \& Miles 1970). Also, annual increments of wood gradually engulf the buds from which sprouting occurs at the base of a stem (Mohamed \& Gimingham 1970). Thus, the effect of the decline in stem density with increasing age is reinforced by a decline in the capacity of the surviving stems to produce new shoots.

ii. Intense heat destroys the buds from which new shoots arise. This happens all too easily when a hot fire moves slowly through dry vegetation. Indeed, after a long spell of hot dry weather, surface peat may ignite and smoulder for days, killing not only all heather plants but also buried seeds. The type and moisture content of the soil have an important bearing on the intensity of heat to which buds are exposed: a molst, peaty soil with a deep layer of litter or moss at the surface acts as an efficient insulator (Whittaker 1961).

iii. Regeneration tends to be better after autunn burning than it is after spring burning (Miller \& Miles 1970). The reason for this effect is not certain, but it may be due to the heather being more or less dormant in October-November, whereas it is just beginning to grow in March-April. Thus, spring burning may be more likely to cause physiological damage to plants. 
iv. Young heather plants are attractive to herbivores, and heavy grazing immediately after a fire can seriously impede regeneration. The pulling action of grazing sheep often uproots seedlings or tears vegetative sprouts away from their attachment to the base of a stem. Also, the continued removal of the green shoots from regenerating heather may so inhibit growth as to allow less palatable competitors to predominate.

v. Finally, vegetative sprouting is affected by climate. Thus, the rate of growth of new heather shoots will vary according to their geographical location in Britain. Within a single moor, growth rate will vary with altitude, aspect and exposure.

\subsubsection{Response to defoliation}

Heather is well adapted to withstand moderate intensities of grazing because of its morphological response to defoliation (Gimingham 1949; Grant \& Hunter 1966, 1968a). The annual removal of about $50 \%$ of the current year's growth leads to a proliferation of new shoots and a greater compactness of growth, so that individual plants become cushion-like with densely packed thin stems. The productivity of the heather is not reduced and may even be enhanced by this level of grazing, as is the concentration of nutrients, especially nitrogen, in the green shoots. On the other hand, flowering is much reduced because all blooms are borne on the current year's shoots. However, one of the most important effects of a $50 \%$ grazing regime is that the continual removal of shoots that would otherwise become lignified inhibits the build-up of woody material by heather plants.

Moderate grazing thus slows the process of physiological ageing: the heather is maintained as a short, vigorous stand with a high density of rooted stems and a high ratio of green shoots to woody tissue in the canopy. The relatively high nutrient content of such heather is 1 ikely to be beneficial to herbivores.

Heather is, however, intolerant of heavy grazing. Recent research (Grant et al. 1978) has shown that the repeated removal of $80 \%$ of the current season's shoots resulted in reductions of biomass, shoot production, and coverage of the ground by heather, and increased numbers of uprooted plants and broken shoots. The plants' carbohydrate reserves were reduced in autumn, and there is a strong presumption that prolonged heavy grazing of young heather may exhaust food reserves, causing death.

Stands of heather are also grazed by invertebrates. of particular importance is the heather beetle (Lochmaea suturalis). The beetle can be found in most years but only sometimes does severe dieback of the heather result from grazing by the larvae. During such attacks the competitive ability of heather may be reduced, perhaps allowing the spread of other plant species such as Molinia. Apart from using insecticide, little can be done to control the beetle; burning any heather infested by larvae might be effective but is, of course, 1llegal during the main period of attack, July-September. Fires during the legal burning season give no control because the beetles are then hibernating underground. There is, however, biological control of the pest: the insects are often heavily parasitized by the hymenopteran Eulophid chalcid Asecodes mento (Golightly 1962). 


\subsection{Options for managing heather}

\section{2 .1 Grazing}

Heather offers a cheap source of energy and nutrients to the domestic and wild herbivores cropped by man. The principal aninal crops taken from heather moorland in Britain are sheep and red grouse. Red grouse are of little importance on Exmoor and, in any case, cannot be used to manage vegetation towards a desired end. Sheep can used in this way, at least in theory.

Owing to its poor nutritive value, heather alone cannot satisfy a hill ewe's need for energy, especially at 2 critical periods of the year - before mating in autumn and during lactation in spring (Grant \& Milne 1973). At these times, the animal's nutrition has to be boosted by supplementary feeding or by allowing access to fertilized grassland. Most heather moors include a proportion of grassy vegetation. At Exmoor, for example, the 2 main regions of heather moor and the coastal heaths have a high proportion of grassland, $20 \%$ or more (Figure 2.1), and substantial amounts of bracken-dominated ground which often has a grassy understorey. In summer, these moorland grasses offer the best feeding and probably only small amounts of heather are taken. On1y in winter, when supplies of grass have been depleted by grazing and dieback, does heather become important as a dietary component. Even then, the quality of most heather is so poor that voluntary intake by the sheep declines to the extent that they lose weight (Milne et al. 1979).

Thus, the annual utilization of heather on heather moors is generally small, rarely exceeding $15 \%$ of the plants' annual production of shoots and of ten much less. However, experiments have shown that heather is well able to tolerate the removal of up to about $50 \%$ of the annual shoot production (Section 5.1.3). There are sound economic, agronomic and nutritiona1 reasons for increasing the utilization of heather. Economically, heather is a cheap and abundant supply of food for livestock; agronomically, a higher level of utilization would retard ageing and maintain the plant in a vigorous, productive condition with a high concentration of nitrogen and other nutrients in the shoots; nutritionally, heather is a valuable source of cobalt and other trace elements (Thomas 1956). The practical problem is to increase the level of sheep stocking on heather moor without incurring a serious decrease in animal performance.

Two possible solutions have been devised by scientists of the Hill Farming Research Organisation.

i. The first is the wel1-known '2-pasture' system outlined by Eadie (1971), which involves the enclosure of areas of grassland, either indigenous or seeded, sufficient to give the sheep the requisite nutritional boost in autumn and spring. These fenced grasslands are conserved for use during the critical periods. Thereby, a larger stock can be run on the moor with a consequently greater utilization of the heather than would otherwise be the case.

ii. An alternative scheme (Grant \& Milne 1973; Milne \& Grant 1978) is to establish, by surface seeding, small areas of grass within a tract of heather, thereby creating a grass/heather mosaic. Such mosaics also require fencing so that they can be used in the manner of the 2pasture system, or as a supplement to it. This method ensures a high level of utilization of heather within the fenced areas without 
any nutritional penalty. Experiments have shown that the proportion of seeded grass patches anongst the heather should be about $30 \%$ by area. This proportion is sufficient to allow ewes to graze of $40 \%$ of the current year's heather shoots, rear single lambs, and yet show a small weight gain by autumn. The ewes nay lose weight appreciably during winter if they are put back on to unimproved heather moor, but this practice is tolerable as long as they receive a nutritional boost before lambing.

It is important to remember that these systems of improving the utilization of heather were devised specifically for hill farms, with only small amounts of inbye grassland, and not for upland farms of the type found on Exmoor. Indeed, it seems that the HFRO systens are quite inappropriate to most parts of Exmoor because (1) there is already a very high proportion of seeded grassland on the farns, ( $i i$ ) most ewes with lambs are not put out on the moor until early June, 8-10 weeks after lambing, and taken off again in October, and (iii) there is already a high proportion of indigenous grassland forming a natural grass/heather mosaic on the heather moors (Plate 11). Perhaps a better return, short of ploughing and seeding, might be achieved by fertlizing these existing patches of grassland so improving their nutritive value, increasing animal performance, and perhaps utilizing a greater proportion of the heather's annual production. Investment in winter housing might be even nore rewarding.

We are uncertain of the extent to which heather is used by stock on Exmoor. Our brief reconnaissance of the heather moors in March 1979 suggested that some parts, notably at the edges (Plate 10), might be heavily stocked to the extent that much more than $50 \%$ of the current year's growth had been grazed off. However, on many stretches of hinterland, only a negligible proportion of the 1978 production had been taken, especially on the older stands.

It seems reasonable to suppose that, if the methods developed by HFRO were put into practice on some of the inost heathery stretches of Exmoor, for example Dunkery Hill or parts of Wilmersham Common, greater utilization of the heather and increased efficiency of animal production might be achieved. There would, however, be changes in visual amenity, notably additional stock fencing, the replacement of stands of pure heather by heather/grass mosalcs and, due to the increased grazing pressure, only very sparse flowering by the heather. Also, given that (i) precise control over grazing is difficult to achieve in practice, (ii) sheep do not graze uniformly over an area, and (iii) there is a predominance of mineral solls on Exmoor, it is likely that grassy patches would begin to spread at the expense of the heather. This vegetation change would accelerate a trend already evident on several moorland blocks, particularly on the southern heather moors.

\subsubsection{Burning}

Although it is theoretically possible to graze of $50 \%$ of each year's production from heather, maintaining it as a physiologically young stand, this is rarely achieved in practice. Instead, production may exceed utilization by a factor of 10 (Miller \& Watson 1974) and year-by-year there is a steady increase in plant height and accumulation of woody material. Eventually, the heather must be rejuvenated by renoving the accunulated excess production and allowing new shoots to sprout; otherwise, the plant becomes senile. Rejuvenation is usually achieved by burning. 
Two recent publications (Watson \& Miller 1976; Muirburn Working Party 1977) deal at length with the technical and practical aspects of using fire to manage heathery vegetation. Therefore, only a brief surnmary of the main recommendations will be given here.

Assuming that the aim of management is to maintain the dominance and productivity of the heather, burning is best done in the building phase of the life cycle. Regeneration is then likely to be rapid by sprouting from the bases of the burnt stems (Section 5.1.2). Particular care is needed where heather is mixed with grasses or bracken, and it may be necessary to delay burning until the heather has grown tall and dense enough to weaken its competitors. However, plants should never be allowed to enter the degenerate phase, or regeneration may fail completely. It is equally a mistake to burn when the heather is too young to have achieved full cover and competitiveness. Summing up, management to maintain the dominance of heather requires that burning should foster rapid and complete regeneration. This is the best possible insurance against undesirable plant species gaining a foothold, but great care must be taken to burn only during the building phase of the heather's life cycle.

Heather grows at different rates depending on climate, soil type and grazing pressure. Thus, the time taken for a stand to attain the building phase varies widely and it is not possible to generalize about the number of years that should elapse between fires. Each site must be treated according to its merits. The best practical guide to the identification of stands that are ready for burning is the heather's height. In general, heather should not be burned before it has attained a height of $20 \mathrm{~cm}$ and it should not be allowed to exceed $30 \mathrm{~cm}$. However, in stands containing bracken or purple moor-grass, it is expedient to allow heather to grow taller than its competitors before the burning. Also, when burning for the benefit of red grouse, it is desirable to provide cover for the birds by allowing small patches to grow to $40 \mathrm{~cm}$.

Applying this criterion to the heather stands investigated during our reconnaissance of Exmoor in March 1979, it appears that, at Wilmersham Common, burning should normally be at intervals of not less than 6 years or more than 10 years (Figure 5.1); at Brendon Common, the rotation is slightly longer, 6-12 years. Reference to Figure 5.2 shows that stem densities are at their highest levels at these ages and that there is a rapid decline once the heather exceeds 15 years of age. The consequences of allowing heather to become senile before burning aro well illustrated in Plates 5 and 6 . At Wilmersham Common (Plate 5), a burnt 23 year old heather stand was regenerating much more slowly and sparsely than a neighbouring 7 year old stand; and at Withypool Common (Plate 6), heather aged 19 years had completely failed to regenerate after fire. On the other hand, especially rapid regeneration was seen at Brendon Common (SS 758448), where a stand of 1700 stems per square metre, burned in spring 1978 at the age of 7 years, had regrown to cover more than $60 \%$ of the ground after only one summer.

The above rotations are short by scottish standards: at $400 \mathrm{~m}$ in the eastern Highlands, burning need be no more frequent than once every 15-20 years. Presumably, the difference is a result of the cooler, shorter growing season and less fertile soils on the northern moors. However, not all Exmoor rotations are short. For example, the slow growth of heather on an exposed part of the coastal heaths at North Hill (see Section 2.3.3) suggests that a 15-20 year rotation may be appropriate there. 
Figure 5.1 Height of heather stands in relation to their age at

(a) Wilmersham Common (400-440 m altitude) and

(b) Brendon Common (380-400 m)
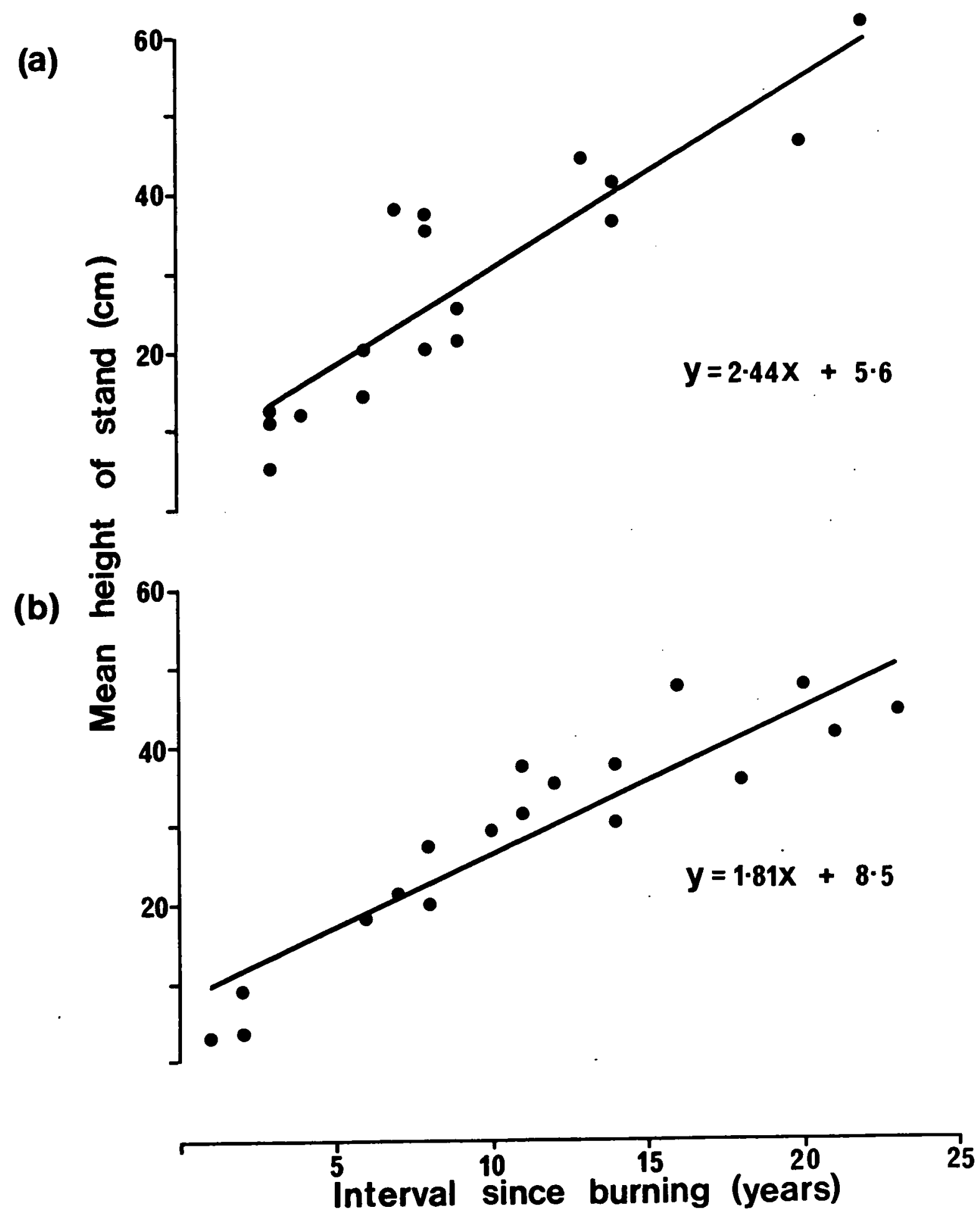
Figure 5.2 Density of rooted heather stems in relation to age of stand at (a) Wilmersham Common and (b) Brendon Common
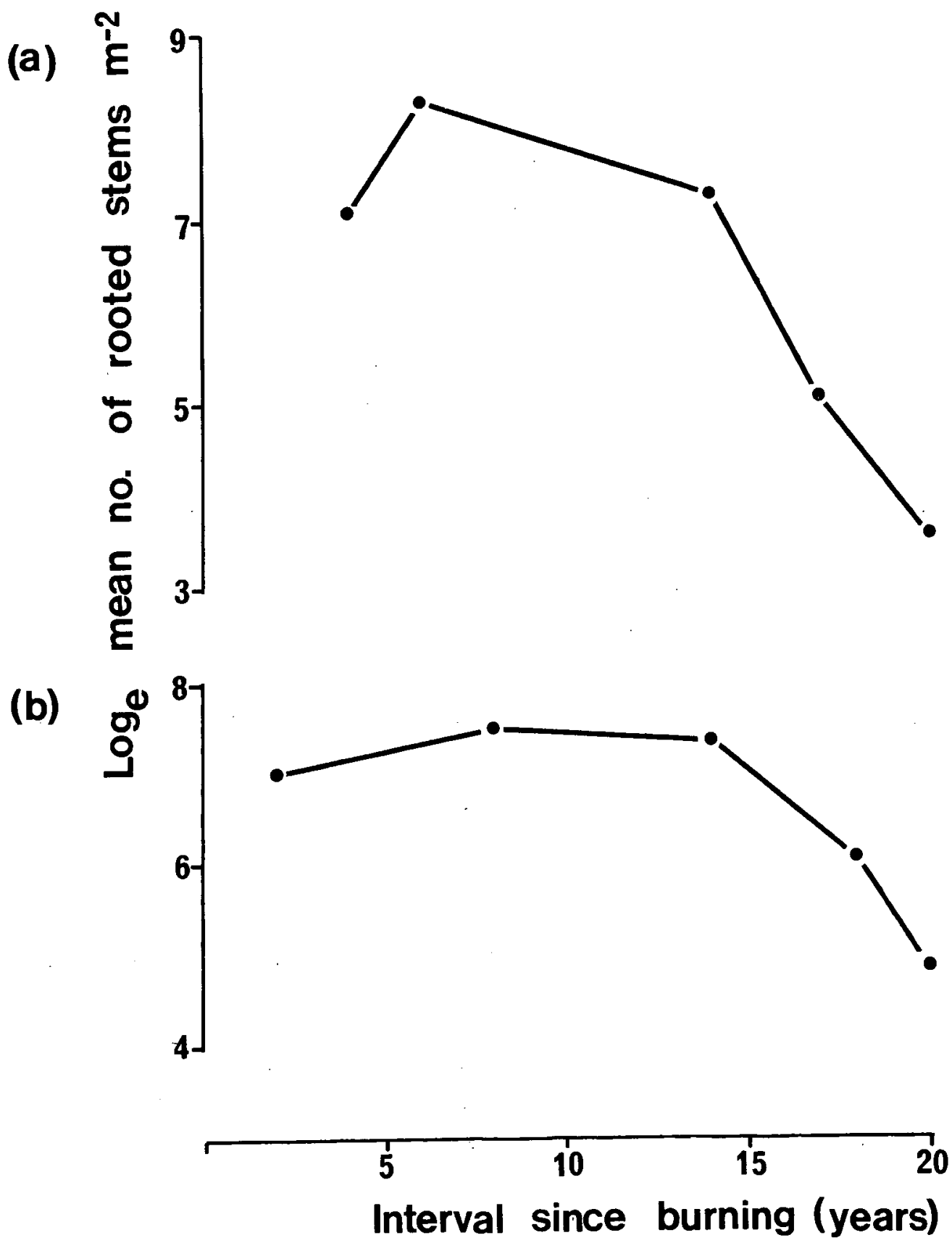
It is worth noting that burning can also be used deliberately to destroy the dominance of heather, and, on suitable soils, to cause its replacement by such desirable grasses as bents and fescues. Burning on a short rotation, coupled with heavy grazing to reduce the vigour of the regenerating heather, can precipitate rapid changes of botanical composition. Modest dressings of lime and fertilizer may accelerate a process which is already happening, possibly inadvertently, on many parts of the southern heather moors.

Once a rotation suited to a particular situation has been decided, the proportion of the moor that must be burned each year becomes fixed. If, for example, the heather takes about 8 years to grow to $30 \mathrm{~cm}$, one-eighth of the moor should be burned each year; if the regrowth period is 12 years, one-twelfth should be burned, and so on. The management of heather specifically for the benefit of herbivores also requires that the size, shape and dispersion of the burnt patches should be planned and controlled. The exact site and shape depend on whether the burning is primarily for the benefit of red grouse or sheep (Miller \& Watson 1974).

For grouse, it is important to burn long narrow strips no more than $30 \mathrm{~m}$ wide. Each grouse territory (normally 2-5 ha in size) will then contain, in close proximity to one another, short accessible heather for feeding and taller stands for cover. To maximize grouse numbers, the pattern of tall and short heather should be on as small a scale as possible: the smallest territories, and therefore the densest breeding stocks, occur where there are numerous small patches of heather of different ages (Miller \& Watson 1978).

In the case of sheep, fires can be larger. Nevertheless, the patches should be much smaller than the 30-50 ha over which sheep normally range. A patch size of 5-10 ha would ensure that the animals have available a mosaic of heather stands of varied age and botanical composition from which to select their diet. Ideally, these mosaics, whether on a small scale for grouse or on a larger scale for sheep, should be distributed over the entire moor to encourage an even dispersion of the stock and, in the case of sheep, as a safeguard against localized heavy grazing.

Heather burning is, therefore, not a straightforward operation. For the best results, there is need for a considered burning policy, and the execution of the policy requires careful planning and strict control over the fires. Detalled guidelines for planning and control are set out elsewhere (Watson \& Miller 1976; Muirburn Working Party 1977).

\subsubsection{Cutting}

Heather can be cut by various types of machines designed for scrub clearance or even, on suitably smooth terrain, by a forage-harvester. The advantages of cutting are that 1 t can be done in wet weather, when burning is impossible, or between 1 Apr 11 and 31 Dctober, when burning is 11 legal. Unlike burning, cutting does not kill the buds which sprout new growth and very rapid, prolific regeneration has been measured on experimentally clipped plots from which the cut material was renoved (Miller \& Miles 1970).

However, this method of rejuvenating old heather also has considerable disadvantages when compared with burning.

1. Large amounts of debris are left lying on the ground, unless special arrangements are made to collect it. 
ii. There is no immediate release of inorganic nutrients in the form of ash (although it is uncertain to what extent these are taken up by plants after burning).

iii. Some machines tear rather than cut the heather stems, which apparently results in poor regeneration.

iv. It is a very slow operation.

v. It can be used only on areas accessible to tractors.

Some Scottish estates with suitable equipment and terrain have experimented with heather-cutting machinery, but regeneration was usually poor, perhaps because the cut heather was not removed. Experience on flat ground in the New Forest, where heather has been mown since the 19 th century, indicates that regeneration can be satisfactory if a.1 cut material is taken away. For routine management of heather, cutting is no real alternative to burning because of difficulties of access to rough or steep ground and because of the slowness, and hence the relatively high cost, of the operation. It is, however, useful as an adjunct to burning, and particularly for making fire-breaks.

\subsubsection{Fertilizing}

Several studies in eastern scotland have centred on the response of heather and of red grouse to applications of nitrogenous and phosphatic fertilizers. Added nitrogen resulted in an increased yield of heather shoots with a higher content of nitrogen, but added phosphorus had no effect on growth, although it was absorbed by the plant (Miller 1968, 1979).

Application of nitrogenous fertilizer over several hectares of heather moor can improve the breeding success of the resident grouse population and increase their breeding stock (Miller et a1. 1970). However, such treatment is effective only when sheep, cattle and deer are excluded from the fertilized area; otherwise, heavy grazing shortens the height of the heather, decreases its ground cover, and the grouse stock declines (Watson et a1. 1977). Phosphatic fertilizer has no detectable effect on grouse performance.

It would be totally uneconomic to manage large areas of heather moor routinely in this way. The benefits to grouse of a single application of nitrogenous fertilizer last only 2-3 years and depend on fencing to exclude, or at least control, the large herbivores. Moreover, the broadcasting of nitrogenous fertilizer over unfenced moorland to improve the productivity and quality of the heather is by no means the most costeffective way of improving the performance of hill sheep and cattle. Much better returns could be achieved by fertilizing more digestible vegetation such as bent/fescue grassland. In any case, it is perhaps irrational to attempt to benefit livestock by supplying fertilizer to a woody perennial species, when an appreciable proportion of the improved growth takes the form of inedible increments of wood. It is quite a different matter, of course, if the wood is the desired product, as in forestry plantations.

The only sound agricultural case that can be made for fertilizing heather is when there is a desire to supplant it with grass species which are much more palatable and digestible to livestock. Well-drained mineral soils supporting a mixed vegetation of heather and grasses are a widespread 
feature of Exmoor. The application of lime and fertilizer at such sites would increase grazing intensities and so expedite the replacement of the heather by grass. This process is already occurring at several places without the application of fertilizers (Section 6.2).

\subsubsection{Other management options}

Controlling the invasion of the heather stand by unwanted species may be assisted by the use of herbicides, and details of selective herbicides are given later (Section 6.2.1). Although such treatment is not a normal practice in the management of heather moor, it may be of value, in association with burning, where the latter would cause an increase in unwanted species such as purple moor-grass or bracken. Where it is desirable to re-establish heather moor and the existing heather is in the degenerate phase or is absent, the application of 11 ter and organic topsoil from areas with vigorous heather would be one way of sowing viable seeds. The use of herbicides and surface seeding are economically unacceptable for management for sheep or grouse, but may be suitable in areas where the landscape value of heather moorland is high. Techniques for these management practices need to be examined further before they can be applied. 


\section{ECOLOGICAL CONSEQUENCES OF PRESENT MANAGEMENT PRACTICES}

The loss of heather moorland through agricultural improvement is the most obvious change on Exmoor but other, more gradual, changes are taking place under the present management. The present chapter discusses current and possible future changes in both plants and animals, based on observation of the current state of the moorland and its species, and on ecological experience in other areas. It must be emphasized, however, that the response of the flora and fauna to management practices varies with the local soil and climatic conditions and with the timing and intensity of the management practice. Thus, the conclusions must be treated with caution until they can be verified by more detailed study.

\subsection{Losses from the flora}

As long as substantial areas of moorland remain within the National Park, only rare and uncommon species are at risk. There has not been sufficient time under the contract to obtain access to, and to collate, the existing information on rare plant distribution. The prime sources are the records of the Somerset Trust for Nature Conservation, the Nature Conservancy Council, ITE's Biological Records Centre, the Exmoor Natural History Society and its members. However, given the past rate of conversion of moorland to sown grassland, together with locally intensive grazing pressures and frequent burning, at least some rare species will almost certainly have declined in abundance, possibly even becoming locally extinct. This has apparently happened with fir clubmoss (Lycopodium

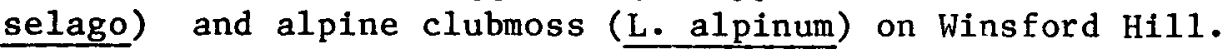

Moorland vegetation is killed immediately, and usually completely, by ploughing and reseeding, though the changes are slower where less drastic cultivation is used. However, whereas abundant species like heather can eventually recolonize old sown grasslands adjacent to moorland if intensive grazing is stopped, rare species are very unlikely ever to do so. There are several reasons for this inability. First, rare species inevitably have a very sparse seed production, so it is statistically improbable that a seed or other propagule will ever fall in a suitable niche in a given area over a short timescale. Other reasons are those causing the species to be rare in the first place: in particular, a need for specialized (and therefore uncommon) habitat conditions for establishment and/or survival and growth, poor competitive ability, and poor regenerative capacity. Plants are often rare when they are growing at the edge of their geographical range; examples on Exmoor include fir clubmoss, stag's-horn moss (Lycopodium clavatum), alpine clubmoss, parsley fern, and lesser twayblade (Listera cordata). Many species require specialized habitat conditions, whether for growth, as is the case for many bog species, or for establishment. For example, the ubiquitous bracken seems rarely able to establish new plants from spores, and only escapes relative rarity by virtue of its ability to spread vigorously by underground stems. Combinations of these characteristics cause rarity and make re-establishment of a particular rare species in a given location a very unlikely event. As it is, many rare species probably persist only by vegetative regeneration, the original ancestral plant having become established under markedly different climatic, biotic or hydrological conditions. 
Management practices other than outright moorland conversion can have equally profound effects over a longer timescale. Repeated burning will eliminate fire-sensitive species; many bryophytes and lichens characteristic of bogs are particularly susceptible. Draining bog and marshland kills a variety of moisture-requiring species like Sphagnum mosses, sundews (Drosera spp.), cotton-grasses (Eriophorum spp.) and butterworts (Pinguicula spp.). Grazing can profoundly reduce the abundance of particular species and, on moorland, probably interacts with the ef fects of burning. The apparent extinction since 1923 of fir clubmoss and alpine clubmoss on Winsford Hill may well have been caused by the combined debilitating effects of grazing, trampling and burning at current levels.

The activities of the public can also be important. The picking of blooms, and even the digging up of entire plants for transfer to gardens seem to have caused a decrease in many species in Britain, sometimes to the point of near extinction, as with mezereon (Daphne mezereum) and the lady'sslipper orchid (Cypripedium calceolus). While there are no national rarities on Exmoor, many of the local rarities are always at risk from casual collectors. Any policies which encourage a greater use of the moorlands by the public for walking should bear this risk in mind.

\subsection{Stability of the vegetation}

It is frequently not realized that all vegetation is constantly changing, with individual plants establishing, growing and dying. Further, except in extreme environments, the vegetation tends to undergo succession, a process involving a series of species population changes with time. Over most of Britain, and probably all of Exmoor, succession tends to lead to the eventual predominance of shrubs and trees. However, all forest stands tend periodically to be naturally disrupted, in Britain by windfall in particular, as well as by death from old age. The resulting gaps will frequently be occupled by shrubby or herbaceous vegetation, and succession begins anew. (Processes of vegetation change are discussed in more detail by Miles 1979.) It is against this background of natural change that the stability of moorland vegetation needs to be considered.

Most of the moorland vegetation of upland Britain has developed since the destruction of the original woodland cover in prehistoric and historic times. Limited evidence from peat profiles indicates that deforestation on Exmoor began in Neolithic times (Merryfield \& Moore 1974). Al1 Exmoor, with the possible exception of the nost exposed hill tops like Dunkery Beacon, probably has the potential to develop a natural cover of scrub and woodland (see plate 12). This succession has been prevented only by grazing and burning. The present great varlability of the moorland vegetation is mainly a result of the interaction of natural variations in soll, hydrology and climate with centuries of grazing and burning, the intensities and frequencies having varied in space and time. The preponderance of heathery vegetation outside the old Exmoor Forest reflects the predominant influence of past persistent burning with relatively light grazing pressures. The development of the present, mainly grassy, vegetation of the Forest (Plates 2 and 3 ) reflects a history of much more intensive grazing.

The vegetation of any area is fntrinslcally unstable. Changes in the composition and structure of a community result from the patterns of growth and death of individual species, from competition between species, from changes in soil conditions brought about by the plants themselves or by 
animals, or from change and variation in climate. Added to these factors is the effect of changing management by man, which includes small changes in stock type or density, or in shepherding. This instability is demonstrated we11 by examining the edges of blocks of heather moorland, where the heather-dominant vegetation typically gives way to patches of grassland, bracken, gorse, and sometimes hawthorn (Crataegus monogyna) or other woody scrub. An examination by us of some moorland edges suggested that this fringe vegetation is tending to spread at the expense of heather. In places, these edge effects are considerable. Figure 6.1 shows such effects at Winsford Hill, where the central block of heather (which gives Winsford Hill a heathery appearance to passing motorists) now amounts to only about $56 \%$ of the total area.

These edge effects are largely caused by a greater pressure from grazing animals at the moorland margins. There are many reasons for this concentration of animals. Supplementary feeding of out-wintered livestock (cattle and ponies on Winsford Hill, sheep on the northern heather moors) will tend to occur at convenient access points, ie beside roads or tracks just inside a moorland area. Livestock driven daily on and off a moor range less widely, and tend to congregate nearer the edge, than do livestock living permanently on the moor. During bad weather, all livestock will seek shelter; marginal scrub, woodlands, walls and hedges, especially the characteristic Exmoor hedgerows of beech on stone or turf-faced banks, will usually constitute the best available shelter, and thus cause a local concentration of animals. Free-ranging animals can wander till they come to an obstacle; an animal meeting a boundary fence or wall frequently follows it for a while rather than turn immediately back on the moorland expanse - heavily trampled zones, or even well-defined animal tracks running parallel to a boundary, are commonplace. It also seems likely that wild herbivores, such as brown hares or the Exmoor red deer, which may be only transient visitors to moorland, will be found to a greater extent at the edges. The pressures for vegetation change are thus usually far greater at moorland edges than on the open moor.

In considering the balance between heather-dominant and non-heathery vegetation on Exmoor, edge effects are particularly important, partly because the heather moors usually have pronounced marginal zones of non-heathery or less heathery vegetation, and partly because, with increasing fragmentation of the moorland, the total perimeter increases. As a result, a high proportion of vegetation is adjacent to the moorland edge and therefore is either already changed or potentially at risk. It is thus of value to consider how a given width of a marginal vegetation zone influences the remaining proportion of unchanged vegetation. For regular geometrical shapes, precise mathematical formulae can be derived showing the relationship of total area, marginal zone width, and the remaining central area. Appendix 6 shows that, for all except very small blocks of moorland, a knowledge of the total area, the perimeter length and the width of the marginal zone enables a surprisingly accurate prediction to be made of the area of the remaining central part, by assuming the moorland block to be circular. Thus, the area of the central part, $P_{r}$, expressed as a proportion of the total area, can be estimated from the equation:

$$
\mathrm{P}_{\mathrm{r}}=[1-(\mathrm{d} / 2 \mathrm{Q})]^{2}
$$

where $d$ is the width of the marginal zone, and $Q$ is the area:perimeter ratio (in the same units of distance). 
Figure 6.1 Map of 'edge effect' on Winsford Hill, showing the central heather-dominant area (stippled) and the marginal non-heathery vegetation

(The map was produced from Meridian Airways Ltd, 1:25 000 uncontrolled mosaic, using the relevant 1:10 000 prints as an aid to interpretation)

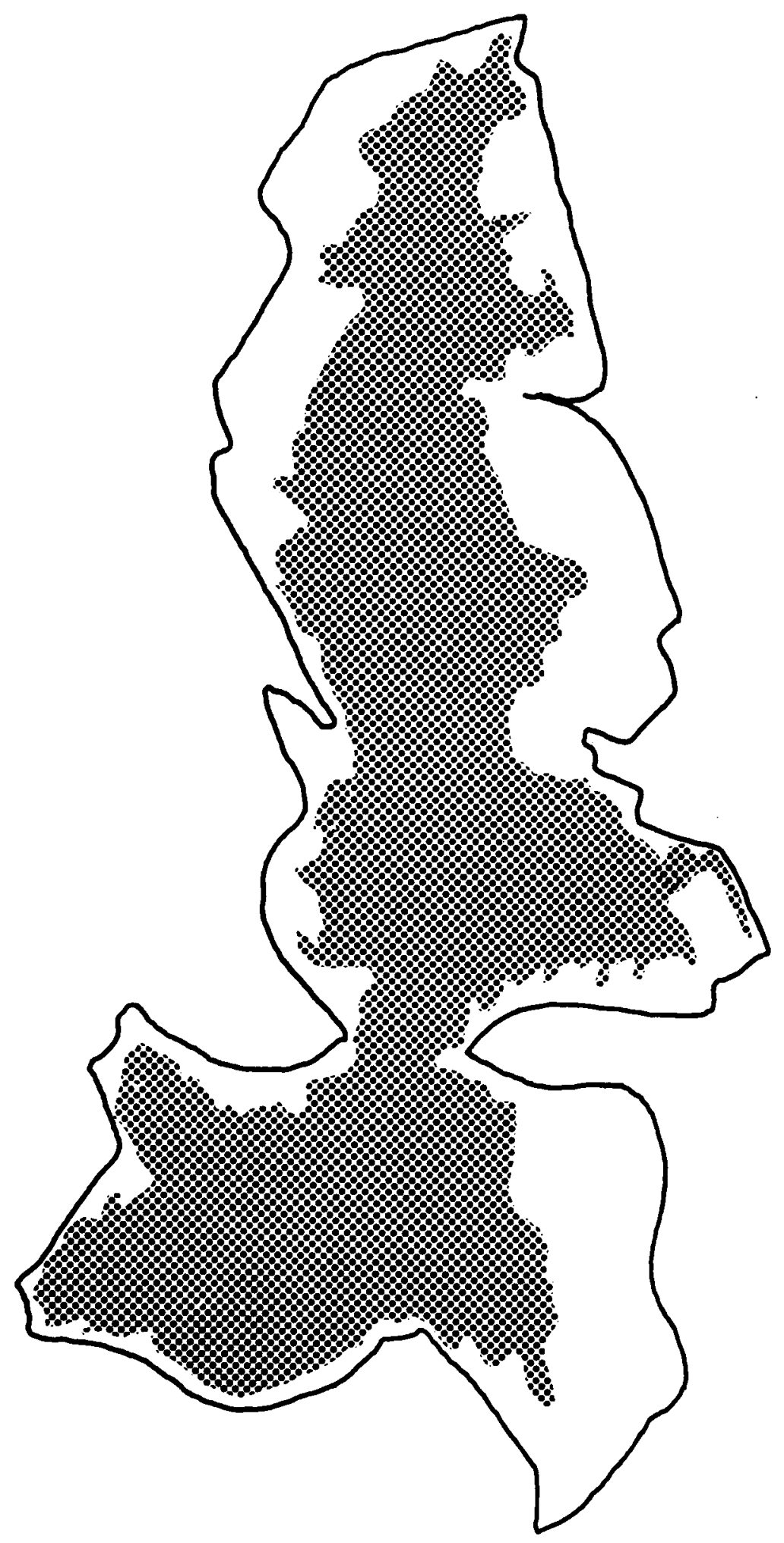


Table 6.1 shows, for 10 different sized moorlands blocks, what the areas of the remaining central blocks of heather would be, expressed as a proportion of the total, given non-heathery marginal zones varying frou $50-500 \mathrm{~m}$ in width. These zone widths are realistic for Exmoor: the mean marginal zone width on Winsford Hill (see Figure 6.1) is $200 \mathrm{~m}$, and the maximum is about $500 \mathrm{~m}$. The figures indicate the vulnerability of the Exmoor heather moors to marginal change. Even on Dunkery Hill and Brendon Common, the 2 largest blocks of heather moorland now existing, a $50 \mathrm{~m}$ marginal zone occupies $7-10 \%$ of the total area. Given a 500 m margin, 100-ha blocks of continuous heather would remain only on these 2 moors. Although a 133-ha block would persist on Withypool Common, this central area is not pure heather. As a heather moor, Withypool is doubtfuly viable even as it is now (see section $6.2 .2)$.

\subsubsection{Invasive species}

The term 'invasive species' is used here simply to denote those species that currently appear to be becoming more abundant within either moorland or converted grassland, such that they change the appearance of the vegetation even to the casual or lay observer. By this definition, there seem to be no important invasive species in the central grass moors region. In the heather moor regions, however, the following are obvious, listed in decreasing order of apparent importance in terms of relative frequency and ground covered: purple moor-grass, gorse, bracken, and trees and shrubs considered as a group. In the converted grasslands, only rushes are obvious.

\subsubsection{Purple moor-grass}

Purple moor-grass is one of the most abundant species throughout the central grass moors region (see Section 2.3.2), but any further increase in its abundance here will not markedly change the appearance of the vegetation. In the other regions, however, characterized by a predominance of heathery vegetation, any large increase in purple moor-grass will have a substantial visual impact. Analysis of $R$ Williams vegetation data suggested that, while vegetation containing abundant purple moor-grass is infrequent in the coastal and Brendon heath regions, in the northern and southern heather moor regions, over one-fifth of the vegetation contains more than $20 \%$ cover of this species (see Appendix 4). In such locations, there is a real risk of a substantial increase in abundance of purple moor-grass, as frequent burning favours it at the expense of heather (McVean \& Ratcliffe 1962; Grant et al. 1963).

The mechanism of this change is two-fold. Purple moor-grass is a completely deciduous species, and heather is usually burnt at a period when the moor grass is present only as dormant buds, buried in the soil and protected from most fires. Its capacity to grow in spring after fire is thus unimpaired. In contrast, heather takes several years to produce a new canopy after fire. In the meantime, the moor-grass has a competitive advantage, and may even reduce the cover of the eventual new heather canopy. Second, the presence of abundant purple moor-grass litter enables a fire to burn across a very young heather stand which it could not otherwise do. Very young heather tends to be killed by fire. Thus, on one lowland heath in Hampshire, where only $2 \%$ of building phase heather stools failed to regenerate after a fire, on a part containing enough purple moor-grass to permit annual burning, $61 \%$ of heather stools failed to regenerate after being burnt twice in 2 consecutive years (Miles 1981). Burning also tends to favour purple moor-grass at the expense of other grasses. 


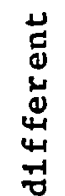

동ㅇㅇ

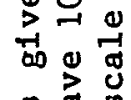

品 要。

을응

岂

。

出 己े

ㄱํㅇ :

은일

ธํㅗㄴ

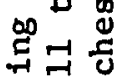

可

覀出

过岩号

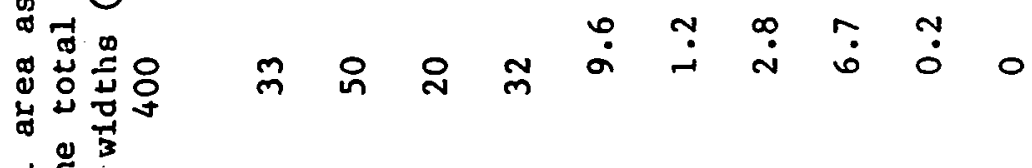

क市

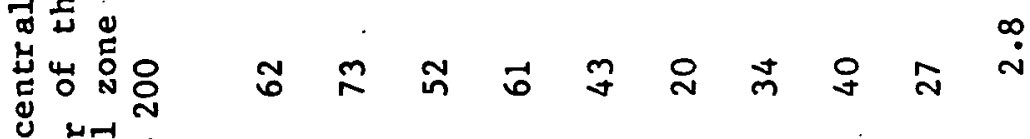
की

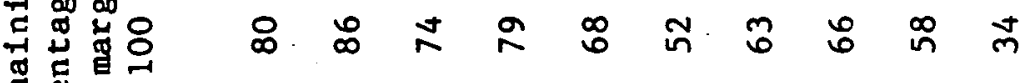
घ

世出站

$$
\text { ㅇำ }
$$

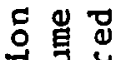

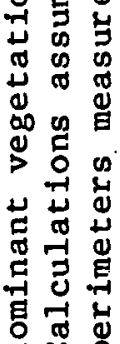

$\ddot{\Delta}$

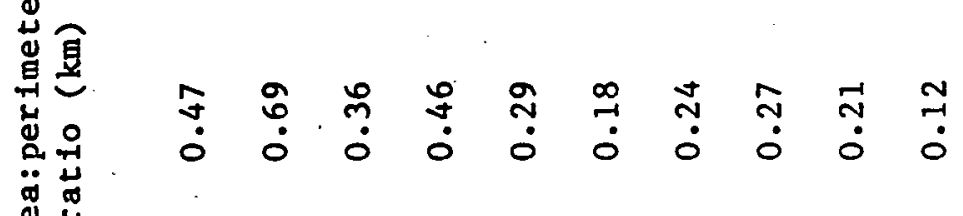

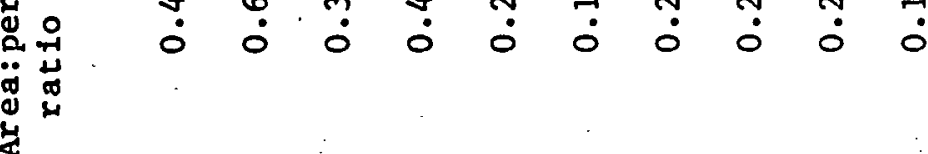

$\circ 0$

is

5 \&

胥

㟧 牙客

范

苟若

중

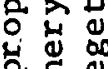

品

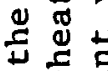

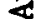

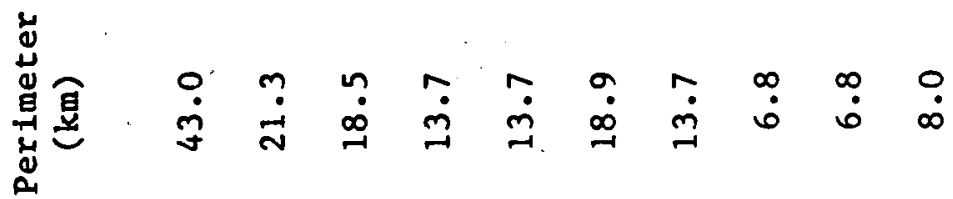

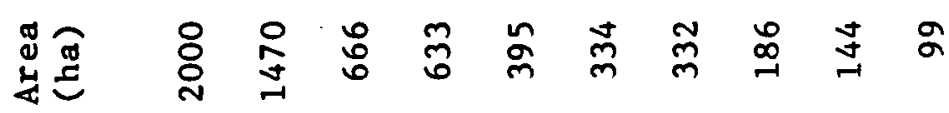


Our reconnaissance of Exmoor, coupled with examination of aerial. photographs, suggests that purple moor-grass has indeed been becoming more abundant locally in the northern heather moor region, but widely over the southern heather moors. We were particularly impressed by the situation on Withypool Common and on North Molton Ridge, where purple moor-grass is ubiquitous and varies in abundance from less than $20 \%$ cover to co-dominant and dominant. It is likely that a comparison of recent with early post-war aerial photographs would indicate that ' the species has increased considerably over that period. More importantly, however, it seems inevitable that there will be a continued increase in purple moor-grass and a decrease in heather in the future, because a substantial proportion of the ground on these 2 moors bears co-dominant purple moor-grass and heather in the 15-25+ years age band. If such vegetation is not burnt, the heather will mostly die of old age within the next 10 years or so, and will be replaced by expansion of the associated species, chiefly purple moor-grass. Regeneration of heather from seed will not occur, even though abundant viable seed exists in the topsoil, because of the dense grassy sward. On the other hand, if the vegetation is burnt, the heather is now so old that vegetative regeneration will be very poor, and will suffer from competition by the purple moor-grass (see plate 6 and section $5 \cdot 1 \cdot 2)$.

For example, we noted an area on Withypool Common (SS 835347) where the vegetation was chiefly 19 year old heather and purple moor-grass, each with about 50\% cover. A patch of this vegetation had been burnt in 1976-77 and the regenerating heather, had produced much less than $5 \%$ cover in the intervening 2 years. In another patch burnt one year ago, less than $1 \%$ of heather stools was regenerating vegetatively. This very poor regeneration was probably due to 3 factors: the advanced physiological age of the heather, a low heather stem density, and competition from the purple moor-grass. We have no way of knowing what the heather regeneration would have been in the absence of the purple moor-grass, but indirect estimates suggest it might have been in the order of $20 \%$. Clearly, however, the heather at this site, and probably over much of the southern heather moors, will be increasingly replaced by purple moor-grass in the near future, whether or not it is burnt, unless drastic steps are taken.

Purple moor-grass can be controlled by grazing, shading, and herbicide treatment.

i. Imposed heavy grazing eliminates purple moor-grass (and also heather), and on mineral solls causes a trend to a bent/fescue grassland. Thus, on an upland grassland at Llety in the Cambrian Mountains, a grazing intensity of 26 sheep per hectare from early May to october (the period when purple moor-grass is in leaf) caused a decline from an initial $55 \%$ by weight of purple moor-grass to only $14 \%$ after 2 years (Jones 1967). Grazing intensities of 17 and 7.5 sheep per hectare caused decreases to $29 \%$ and $36 \%$, respectively.

ii. Under natural conditions, purple moor-grass is controlled by shading during the succession to scrub and woodland, as also is heather. When present in only small quantities, it seems to be similarly controlled by a vigorously regenerating heather stand.

iii. Purple moor-grass has been successfully controlled experimentally using the selective herbicide dalapon (2,2-dichloropropionic acid). A spraying rate of $5.6 \mathrm{~kg}$ per hectare of dalapon killed all but a few per cent of purple moor-grass at a site in the southern uplands of 
Scotland (King \& Davies 1963), but this residue had increased to 5-12\% after 2-3 years. Fryer and Makepeace (1972) recommend a rate of $11.2 \mathrm{~kg}$ per hectare for 'excellent' control, while $G \mathrm{E}$ Davies (personal communication) recommended $16.8 \mathrm{~kg}$ per hectare to be certain of obtaining a complete kill. At a site in Wester Ross, sprayed at a rate of $23.4 \mathrm{~kg}$ per hectare after burning in late May, there was only $1 \%$ of the original purple moor-grass cover 3 years after spraying, while $44.8 \mathrm{~kg}$ per hectare gave a $100 \% \mathrm{kill}$.

\subsubsection{Gorse}

Stands of gorse, but not dwarf furze, are widespread in all the Exmoor regions except on the grass moors. Gorse seems to occur mainly beside roads and tracks (see Plate 1) on the coastal heaths and northern heather moors. In the southern heather moors, however, it is also locally abundant on the moorland expanse, the best example we saw being the south side of Anstey Common.

Tubbs and Jones (1964) noted that, in the New Forest, gorse characteristically grew on disturbed ground. This appears to be equally true on Exmoor and other parts of Britain. The reason for this association with disturbance does not seem to be known. Tubbs and Jones suggested that disturbed soil fulfilled a nutritional need of the species not met by undisturbed profiles under heathland. Certainly, growth of gorse seedlings in disturbed acid heathland soll may be checked because of a delay in infection by nodule-forming bacteria (Miles 1974a), and it is possible that infection may be st111 further inhibited, or even prevented, in undisturbed soil. However, gorse may also show a similar seed dormancy to broom (Sarothamnus scoparius), which also tends not to establish in undisturbed vegetation, or to regenerate itself from seed when stands die of old age. However, buried viable seeds can persist in the soll for long periods, probably decades, because of the hard seed coat. When soil is bared by disturbance, seeds can germinate, but they tend to remain dormant in very small patches of disturbed ground and to germinate only where quite large patches of soil are exposed (Miles 1974b). Thus, in many parts of the uplands, abundant young broom plants can be found following gross soll disturbance, such as beside road widening schemes or where land has been heavily disturbed by livestock.

Locally, there seems to have been quite a substantial increase in the extent of gorse stands during the last 20-30 years. For example, on the south side of Anstey Common and on Withypool Common beside the Withypool to Hawkridge road, the oldest bushes tend to be found nearest to roads and tracks, and the youngest further out on the moorland. This increase suggests that there has been a greater trampling pressure by 11 vestock, probably ponies and cattle rather than sheep, in these areas.

Measures conventionally recommended to control gorse are (i) burning, (ii) spraying, and (iii) mechanical disturbance.

\section{i. Burning}

Gorse stands are frequently burnt, apparently as an attempted control measure. Burning is usually quite ineffective. Gorse, 1ike heather, sprouts vigorously again from the base after burning or cutting (see Plate 8), and the stand is thus rejuvenated. In a 14 year old stand of gorse we examined on Withypool Common that had been burnt the year before (SS 845343), over $95 \%$ of all bushes were regenerating 
vegetatively. Also, as with heather, only very old bushes (which would shortly die of old age anyway) may fail to sprout. Thus, adjacent to the above stand, we examined a patch of burnt 24 year old gorse bushes in which fewer than one in 5 of the stools were sprouting again from the base.

A further disadvantage of burning is that the vegetation growing afterwards is temporarily very attractive to livestock and red deer. A. concentration of animals may disturb the ground, thus exposing buried gorse seed to conditions suitable for germination and seedling establishment. In the burnt gorse we examined on Withypool Common, gorse seedlings were frequent where the ground had been severely disturbed but none was observed where the grass sward and the litter layer under the former bushes were intact.

\section{i1. Spraying}

Many authors have found that summer spraying of the herbicide 2,4,5-T $(2,4,5$-trichlorophenoxyacetic acid), applied as the butoxethyl ester in water, gives consistently good control of gorse with few bushes resprouting. A dosage of $2.24-4.48 \mathrm{~kg}$ per hectare has been recommended for British conditions (Fryer \& Makepeace 1972) but, in New Zealand, a rate of only $4 \mathrm{~kg}$ per hectare may necessitate follow-up spraying for a complete kill (Chavasse \& Davenhill 1973), while 8.96 $\mathrm{kg}$ per hectare gave a 99\% kill (Meeklah 1967). Resprouting of cut gorse can be largely prevented by the application of $2,4,5-\mathrm{T}$ in oil to the cut stumps (Fryer \& Makepeace 1972).

Spraying with $2,4,5-\mathrm{T}$ has fallen out of favour because of possible health risks from the contaminant dioxin. However, the newer weedkiller glyphosate (the isopropylamine salt of $\mathrm{N}$-phosphomethyl glycine) also kills gorse, and can be used instead (McCavish 1980; Preest 1980).

1ii. Mechanical destruction

Cutting, like fire, tends to rejuvenate gorse stands. All except very old bushes will resprout from the base. Total grubbing out is effective, and the Park Authority have killed gorse on North Hill by cutting followed by flailing. However, both procedures churn up soil, so great care must be taken not to allow new gorse plants to establish from seed.

To control the further spread of any gorse stand, the essential point seems to be to avoid all ground disturbance which would provide a seed bed, either for incoming seeds or for buried seeds already present. Very large numbers of viable gorse seeds may be present in the soil at any site; Milton (1948) recorded up to 500 per square metre in the top $18 \mathrm{~cm}$ of soil at an upland site in Montgomeryshire. Under these conditions, almost any sod overturned by passing hooves could lead to the establishment of a new gorse bush. Further, because of the cost of eradicating existing gorse stands, and the risk merely of rejuvenating them or of inadvertently establishing new plants from buried seed, serious consideration should be given simply to take no action. Gorse bushes on Exmoor seem mostly to reach their maximum height at 12-20 years. Thus, by waiting 10-15 years, a gorse problem will largely remove itself, provided that the ground is not poached or otherwise disturbed so as to permit new plants to establish from burled seed. It should also be borne in mind that gorse scrub is a 
valuable habitat for many small bird species and, from this point of view, its eradication is undesirable (see Section 6.5).

\subsubsection{Bracken}

Bracken is a ubiquitous component of the moorland vegetation on Exmoor, tending to be especially abundant on the moorland fringes and on the sides of the coombes, though it is less common on the central grass moors. The surveys of Williams and of Davies and Jarinan indicate that there is abundant bracken on over $20 \%$ of the total moorland area, and some bracken on about $30 \%$ of the ground.

New bracken plants formed as a result of sexual reproduction are rare. Bracken owes its success to its ability to spread by its underground stems. Any given patch on a moor has probably spread clonally in this way from a single antecedent plant, though some may have originated from fragments of older patches. On good soil, bracken can probably spread more than 0.5 metres per year.

If a heather stand is adjacent to bracken, the bracken can spread in and kill the heather where the fronds are most dense (Watt 1955). This replacement of heather is favoured by fire which, by disrupting the heather canopy, temporarily reduces its competitive ability (see Plate 11). Fire effectively maintains bracken stands. Dead bracken fronds on the ground can be burnt, particularly in early spring. As the new fronds have not emerged by then, the bracken is unharmed by fire, whereas woody plants are cut back.

Changes in grazing pressures can also influence bracken. A reduction in cattle grazing, or a change from a predominantly cattle grazing regime to grazing mainly by sheep can permit bracken invasion of grassland. Whereas sheep usually walk between bracken fronds, cattle tend to trample them, thus reducing their competitive vigour. The effects of horses or ponies are unknown.

Bracken frequently exists in very sparse stands with low cover. In grassland, the frond density of such bracken may increase or decrease depending on the grazing regime. In heather, the density may tend to decrease with infrequent burning but increase with frequent burning. A grazing pressure sufficient to weaken the vigour of the heather can also allow the bracken to increase, as is apparently happening at the site on Winsford Hill shown in Plate 7. We did not have time to examine a sample of bracken patches on Exmoor to see what proportions appear to be relatively stable, expanding or declining.

Traditionally, bracken was controlled by repeated cutting during the growing season which exhausts the capacity of the underground stems to send up new fronds. After 2-3 years of such treatment, a dense stand of ta11, vigorous fronds can be reduced to a sparse stand of short fronds with low ground cover. In many parts of the country, bracken was formerly cut for winter bedding for livestock, and locally was cut for burning to produce ash for soap making. Both practices tended to prevent the spread of bracken. The general increase of bracken in the uplands over the last century or so has also been attributed to fewer cattle grazing and therefore reduced trampling, and to more heather burning by shepherds as sheep numbers increased. 
Effective control of bracken is now possible using the selective herbicide asulam (methyl-N-(4-aminobenzenesulphony1)-carbamate). An application rate of 11 litres per hectare of the $40 \%$ weight:volume preparation of May and Baker will give a $95-96 \% \mathrm{kill}$. It is recommended to spray the remaining $4-5 \%$ again in the following year by hand to give $99+\%$ control. Success is determined by follow-up spraying and by stock control. The newer herbicide glyphosate also controls bracken.

\subsubsection{Trees and shrubs}

On Exmoor, there is relatively little colonization of the moorland by trees and shrubs, although, where this does occur, it causes pronounced changes in the appearance of the moor. We saw surprisingly few birch (Betula pendula and B. pubescens); only on parts of North Hill was there any noticeable spread of the species. Very occasionally, small patches of rowan (Sorbus aucuparia) saplings were seen (see plate 12). We were told that rhododendron (Rhododendron ponticum) was spreading on to heather moor land at Cosgate Hill (SS 793489), but we were not able to visit this site. The Park Authority expressed concern that the spread of this species might become a problem on Haddon Hill, but $E$ R Lloyd (personal communication) recalled that rhododendron bushes had been scattered over the hillside there for as long as he could remember, and had not spread markedly in this time.

Rhododendron can spread fairly quickly, however, and form dense thickets. These cast a heavy shade, transmitting only about $2 \%$ of the incident light, and thus precluding the growth of other species below their canopy. Plants can live for at least 100 years and, on suitable moist ground, individual bushes can spread by layering of the outermost branches. Seeds are wind-dispersed, and require a moist bare substrate for germination and establishment. Most seedlings are found on bare mineral soil, humus or rotting wood (Cross 1975).

Hawthorn is the only tree that can be seen frequently on the moors. Scattered individuals of this species are fairly widespread (see Plate 11), except on the central grass moors, and the species is particularly obvious on parts of Winsford Hill (see Plate 6). We briefly examined a stand about $1 \mathrm{~km}$ south of Drayton Knap on Winsford Hill (SS 896317). We determined the age of a few trees by counting annual growth rings (Figure 6.2): the youngest was 6 years old and the oldest almost 100 years.

Extrapolation of Figure 6.2 suggests that the largest tree we saw, with a basal diameter of $40 \mathrm{~cm}$, was about 150 years old. Although not measured, the spread of heights and the spatial pattern of trees, here and elsewhere on Winsford Hill, indicate a very slow and gradual increase in hawthorn numbers over the last 100 years. An interesting feature of Figure 6.2 is the kink in the graph at 20-25 years. This seems to occur when the plants are 1-2 $\mathrm{m}$ high, which, in turn, suggests that the apparent sudden increase in basal diameter growth rate may have resulted from reduced browsing by sheep as more branches grew out of reach.

At low density, as on Exmoor, most trees and large shrubs present negligible control problems, if control is desired. Although many species are fairly resistant to spraying with $2,4,5-\mathrm{T}$, including rhododendron and hawthorn, they are easily felled, and applying either $2,4,5-\mathrm{T}$ in oil or ammonium sulphamate to the cut stumps generally prevents resprouting from the base (Fryer \& Makepeace 1972). Rhododendron may be nore of a problem to fell because it tends to produce a multiplicity of low level or basal 
Figure 6.2 Relationship of age of hawthorn bushes on Winsford Hill to basal stem diameter

(line interpolated by hand)

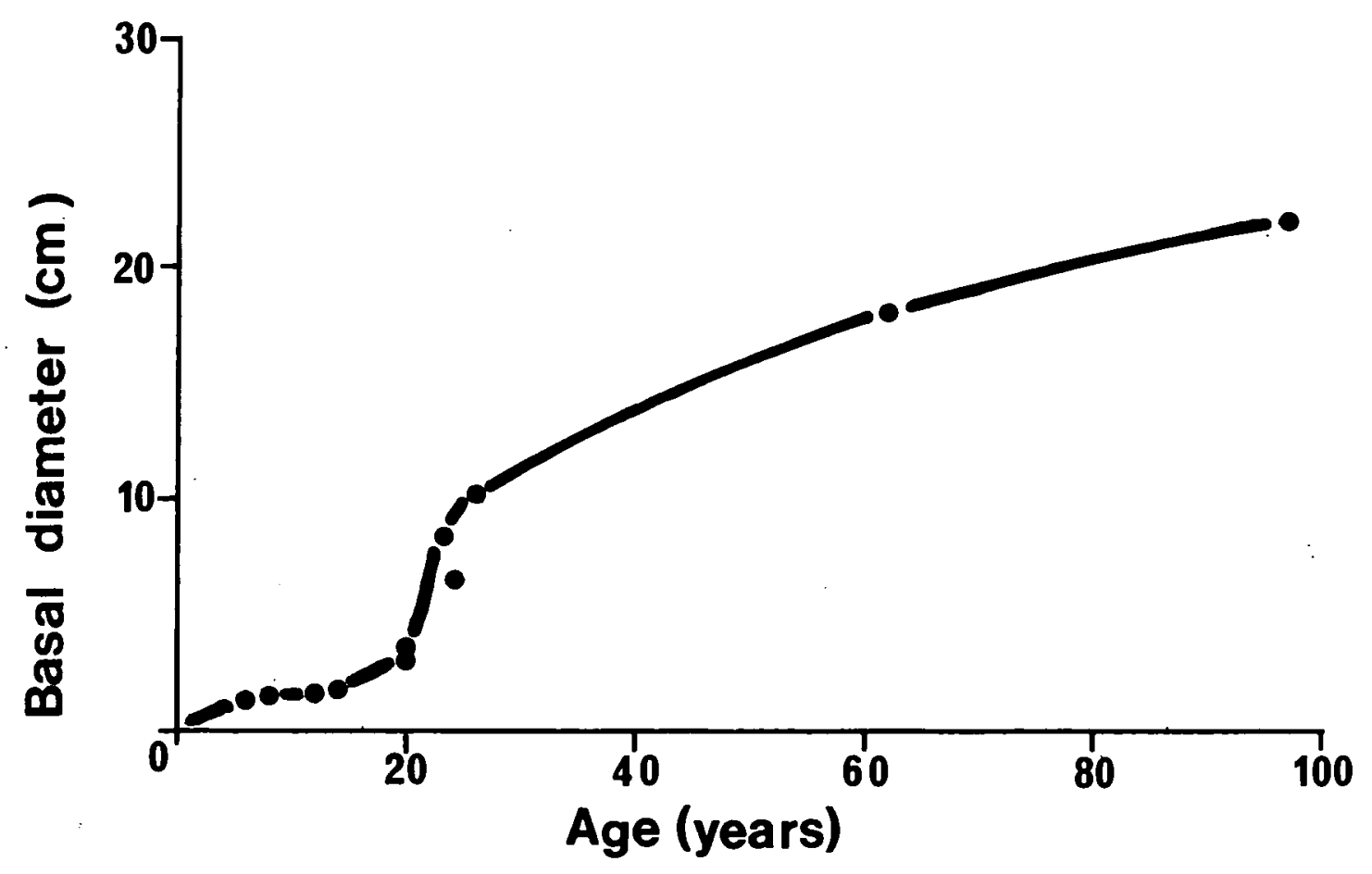


stems, but $2,4,5-\mathrm{T}$ and ammonium sulphate kill the cut stumps. If rhododendron is not wanted, it is a mistake simply to cut or burn the plants. As with heather and gorse, cutting and burning stimulate the sprouting of dormant basal buds, which soon form a new multistemmed thicket. It is probably inadvisable to burn heather close to rhododendron scrub, as burning may create a suitable seed bed in which the winddispersed seeds can establish.

\section{$6 \cdot 2 \cdot 1 \cdot 5$ Rushes}

Except for a few boggy and marshy areas, rushes are not a characteristic part of the moorland vegetation on Exmoor. However, rushes, especially soft rush, are of ten abundant in former moorland converted to grassland. A particularly fine example of rush invasion of pasture can be seen along Twitchen Ridge. Such invasion is associated with wet, poorly drained land, and with a poorly-growing, over-grazed or poached sward. The reasons for the associations are that seeds of soft rush require very high moisture levels for establishment. Also, because of their small size and the fact that they can only germinate in the light, they require bare patches in which to establish. Rushes are prolific seed producers; a dense stand may produce 9.5 million seeds per square metre (Fryer \& Evans 1970). Seed dispersal is efficient. The sma11, light, mucilaginous seeds are dispersed partly by wind and partly by animals, the latter especially after rain when the seeds are sticky (Richards \& Clapham 1941). Seeds can also persist in the soil: over 15000 seeds per square metre of topsoil may be present (M11ton 1948).

The spread of rushes can be prevented by good drainage, and by ensuring a vigorously growing sward, fertilizing if necessary. It is important also not to overgraze or poach the ground and thus create niches in which rush seeds, either dispersing or already present in the soil, can establish. On much of Exmoor, however, with its high rainfall and natural tendency towards surface gleying of the soils, it is possible that no system of drainage may ever reduce surface moisture enough to prevent establishment of rush seeds. Control therefore depends, even more, on good husbandry.

Existing stands of rushes can be killed by cutting followed by ploughing but, unless a vigorous new sward is then created, it is likely that many new rush plants will establish from dormant seeds brought to the surface. Soft rush can be killed by herbicides, though other species are more resistant. The British Crop Protection Council recommend that spraying takes place before flowering and when the rushes are growing vigorously. To improve control, the rushes should be cut about a month after spraying, and fertilizer applied, to help the sward grow over the dead rush clumps (Fryer \& Makepeace 1972). Sultable herbicides are MCPA-salt (salts of 4-chloro-2-methylphenoxacetic acid $1.68 \mathrm{~kg}$ per hectare), 2,4-D-amine (1.40 $\mathrm{kg}$ per hectare), 2,4 ,D-ester $(0.98 \mathrm{~kg}$ per hectare), or glyphosate (6 1 per hectare).

\subsubsection{Possible changes in heather moors}

Excluding moorland conversion, which causes an immediate total 1oss, present management practices on Exmoor seem to be causing a general trend away from dominance by heather. Only in the northern heather moor region are there still extensive tracts of fairly pure heather with relatively insignificant marginal zones of non-heathery vegetation. However, as demonstrated in Section 6.2, even Brendon Common and Dunkery Hill are vulnerable. Proceeding north on the 33223 road out of Simonsbath, it is 
very noticeable that, after crossing the theoretical grass moor/heather moor boundary at Brendon Two Gates (see Plate 2), the moorland is still very grassy. Heather only attains total dominance about one kilometre from Brendon Two Gates. It is not possible, without substantial further investigation, to assess the rate at which this marginal decline in heather dominance may be occurring at present. Apart from the margins, however, the heather in the northern heather moor region is generally fairly pure, and shows no signs of any pronounced decline in dominance.

The situation is different in the coastal heath, southern heather moor and Brendon Heath regions, where the future of heather dominance is uncertain. Here, the heather cover seems to be declining under current management, and its disappearance is more a question of 'when' than of 'if'! Not only do these regions have a smaller proportion of heather-dominant vegetation than the northern heather moor region, but also the dominance is less pronounced (Figure 2.2; Appendices 2 and 4). It has already been noted (Section 6.2 .1 .1 ) that, over much of the southern heather moors, there is a trend towards dominance by purple moor-grass at the expense of heather that probably can now be halted only by instituting drastic changes in management, such as spraying with the selective herbicide dalapon. The remaining heather on Winsford Hill is, exceptionally, still relatively free of purple moor-grass, however.

The coastal heaths are also tending to become grassier but here, with normally better drainage, bristle bent tends to replace the heather on flatter ground, and bracken on the steeper slopes. Locally, dwarf furze seems to have increased, but this is a naturally abundant plant of the coastal heaths, often being co-dominant with heather. The increase in bristle bent on the coastal heaths seems to result mainly from too frequent burning. Heather may be less productive on the exposed coastal areas (see Section 2.3.3), and a burning frequency satisfactory for the rest of Exmoor is probably excessive here. On parts of North Hill, for example, we received the definite impression that burning, and to some extent sheep grazing, had caused the widespread co-dominance and even dominance of bristle bent. It seems likely that burning more of ten than every 15-20 years on the coastal heaths will tend to eliminate the heather.

As well as a trend towards increasing abundance of purple moor-grass on the southern heather moors, gorse seems to be spreading and, more locally, bracken. Of the remaining small patches of moorland in the Brendon Heath region, we were only able to make a cursory examination of Haddon Hill. Here, the heather seemed to be losing dominance, giving way particularly to purple moor-grass. However, the small size of the other remaining moorland patches in this region, coupled with the abundance of bracken and gorse (see Appendices 2 and 4 ), suggests that the heather on these areas may inevitably decline in the future.

As with the northern heather moors, it is impossible to assess the rate at which heather may be declining in these other heathery regions without considerable further investigation. It is possible, however, that, within the next 50 years, dominant heather will no longer exist over any appreciable areas of Withypool Common and North Molton Ridge, and any similar moors with sparse, ageing heather and abundant purple moor-grass.

\subsubsection{Possible changes in grass moors}

Because so high a proportion of the vegetation in the central grass moor region is burnt each year, the vegetation here is almost certainly the most 
stable on Exmoor. Unlike the other regions, there seem to be no major vegetational trends associated with the current moorland management. This is partly because the process of heather elimination, now so obvious elsewhere, was largely completed long ago on the grass moors, and partly because the peatier soils and higher rainfall are not so conducive to the spread of bracken and gorse. Because of the high rainfall and poor drainage, moorland converted to pasture here may be particularly liable to colonization by rushes. Only small changes are likely on the moorland expanses. Fluctuations in the proportions of purple moor-grass and of the sparse remaining heather may occur with variations in burning patterns, shepherding and cattle herding, but these changes will not appreclably influence the appearance of the vegetation.

\subsection{Red deer}

Red deer appear to be thriving on Exmoor and their status is not seriously threatened by current management practices on the moorland. Even if all improvable land were to be ploughed and seeded, it is doubtful if this would adversely affect a stock which is centred on woodland and farmland. Moorland improvements may even be beneficial to deer in creating a larger food supply.

As far as we can judge, the size of the Exmoor population may be relatively stable at present. Assuming that there are $350-450$ hinds in the population, each rearing $0.4-0.5$ calves annually (Section 2.4.1), annual recruitment should be within the range of 140-225 animals. Bearing in mind that deer are polygamous, and that there is discrimination against stags in the annual cull, there is likely to be an excess of hinds. This excess is characteristic of most red deer populations, although there are seldom more than 2 hinds per stag (Mitchell et al. 1977). Thus, annual recruitment to the Exmoor population is likely to be at the upper end of the range 140-225, le close to the number killed by the hunts. Further speculation is pointless.

The chief threats to the continued survival of the deer stock might come from (i) a cessation of the activities of the hunts, which presently provide the main impetus for conservation, and (ii) the large-scale felling of woodlands which provide cover. It would probably take a colncidence of both events to endanger red deer on Exmoor.

\subsection{Birds of particular interest}

\subsubsection{Red grouse}

On Exmoor and Dartmoor, red grouse are at the south-western limits of their world distribution and of the distribution of the closely related sub-species, willow grouse (Lagopus 1. lagopus). Neither specles is found on the heaths of southern Sweden, Denmark or northern France and, unlike the ptarmigan ( $L$. mutus), they are absent from the Alps. Any species requires careful conservation when at the margins of its range, and on Exmoor the red grouse is no exception.

The birds are totally dependent on heather for food and cover (Jenkins et al. 1963). Therefore, their present and future status on Exmoor $\overline{i s}$ inevitably linked with the manner in which the heather noors are used and managed. Grouse are sedentary birds, seldom straying further than about 15 
$m$ from heather tal1 enough (more than $15-20 \mathrm{~cm}$ ) to afford cover. Research has shown that the biggest stocks of grouse are found where the heather is predominantly in the pioneer and building phases, but with plenty of patches of taller plants scattered over the moor (Miller et al. 1966; Picozzi 1968). On areas where an uncontrolled fire burns up tens of hectares, the birds do not take territories until the heather has grown tall enough to provide cover; even then, the territories are usually large and the breeding stock is therefore small. Conversely, wherever there is a mosaic of tall and short heather, territories are small and the breeding stock is large. Thus, to sustain large stocks, the heather must be managed to create structural diversity in the birds' habitat. Planned and controlled burning is the only practicable way to achieve this diversity (Section 5.2.2). From Section 3.3.1, it is clear that little planned and controlled burning is done on Exmoor. Although much of the heather on the northern and southern heather moors is tall enough to provide adequate cover (Table 3.4), there is insufficient control over burning. Individual fires of $30-40$ ha or more are not suitable for sheep, far less for red grouse. It is, therefore, not surprising that grouse numbers are fluctuating at a very low level, and that the species is perhaps on the verge of extinction.

A second factor, predation, may contribute to the small stock of red grouse on Exmoor. On moors in northern Britain, where grouse are of ten abundant, the impact of predators on the breeding stock is usually discounted. Each year many birds fail to get territories and this non-breeding section of the population absorbs any predation (Jenkins et al. 1964). However, the situation may be very different on ground that is marginal for grouse, as on Exmoor, where there are likely to be few surplus birds and predation in late winter by foxes, stoats, sparrowhawks and buzzards may depress the spring breeding stock.

Nest-robbing by foxes and crows (Corvus corone), both probably abundant on Exmoor, may pose an even more serious threat. The average life-span of a grouse is about 18 months and, in most populations, a fresh cohort of young birds is recruited for breeding every year. Therefore, in a small grouse population, such as Exmoor's, severe predation of eggs in summer might reduce the breeding stock in the following spring.

We do not know how many crows and foxes are resident on and around the heather moors. Presumably, there is a large crow population on and near the farmland which will wander on to the moors in search of carrion. In the case of foxes, it is likely that numbers will be carefully husbanded to supply quarry for the dozen or so fox hunts that take place each week from August to April (Section 4.1). In any event, there is no persecution of the fox on the same scale as is practised on Scottish grouse moors.

It has been alleged that disturbance by the public during the breeding season (especially at the Easter Bank Holiday) has depressed grouse numbers on Exmoor (Davies \& Jarman 1978), but this seems unlikely in the light of Picozzi's (1971) findings at the Peak District National Park. He reported that $95 \%$ of visitors did not stray from the main paths, that uncontrolled dogs were not a problem, and that neither the breeding success of grouse nor the numbers shot had declined as a result of public access to moorland. At Exmoor, the most popular tourtst area within the breeding distribution of red grouse is probably Dunkery Beacon. There are several paths to the summit, all of which are well marked and in good condition; in these circumstances, none but the most intrepid hiker prefers to walk through dense heather, in many places more than $20 \mathrm{~cm}$ tall. 
The introduction of fresh stock does not offer a real solution to the problem of the sparse grouse population on Exmoor, even though the birds may have been so established in the first instance. The scarcity of grouse is probably not the result of a lack of vigour amongst the local birds, but is probably caused by deficiencies in their habitat. A more credible prescription to ensure the survival of the Exmoor grouse population, and perhaps to increase the stock, ought to have at least 3 ingredients:

i. Further losses of heather moor should be prevented, whether by deliberate agricultural improvement or otherwise, within the birds' present breeding area. According to Allen (1976), breeding is chiefly from Robin How (SS 9042) on Dunkery Hill to Black Barrow (SS 8344) near the source of Weir Water, but there are other potential1y important centres at Chapman Barrows (SS 6943), Brendon Common (SS 7644) and North Molton Ridge (SS 7732). All these areas are above about $550 \mathrm{~m}$ altitude, suggesting that grouse may be unable to colonize lower ground.

11. A programme of heather burning in narrow strips and small patches should be instituted within the present breeding areas.

i11. There should be vigorous control of the numbers of foxes and crows, not simply within the breeding area but also on surrounding farmland and moor land.

The type of land tenure, the system of farming and the presence of other sporting interests on Exmoor make it unlikely that such a radical change of management could be accomplished. Even if it were, it is uncertain that the grouse stock could ever be husbanded to the high densities achieved on the grouse moors of Yorkshire and Aberdeenshire. Recent research on marginal grouse habitat in western Ireland (Watson \& O'Hare 1979b) suggests that birds reared on small islands of good habitat are lost by emigration to surrounding tracts of second-rate habitat, where they may be rapidly mopped up by predation and starvation. The large area of marginal habitat thus acts as a huge 'sink', siphoning off birds which apparently opt out of competing for territories on the more desirable patches. Such a situation, which may we11 exist on Exmoor, implies that a certain minimal area of suitable habitat is necessary to sustain a large stock of birds. This critical area is unknown but may amount to scores of square kilometres, in which case the grouse population on Exmoor will always be minimal.

\subsubsection{Black grouse}

Much less is known about the detailed habitat requirements for black grouse. The species can occupy a much wider variety of ground than red grouse but, typically, it is a bird of the margins between moorland and woodland. There it can find the dense cover that appears to be essential for nesting.

Unlike red grouse, black grouse have a catholic diet, consuming a variety of items including insects, heather shoots, and the twigs, shoots, buds, leaves, fruits and seeds of many different species. It also visits stubble fields in autumn, takes turnips in winter, and can seriously danage Scots pine (Pinus sylvestris) plantations by dis-budding the young trees (Johnstone 1967). However, the twigs, buds and catkins of birch, willow (Salix spp.), hazel (Corylus avellana) and alder (Alnus glutinosa) make up the greatest proportion of its diet. This fact has led to the suggestion that the sparse distribution of black grouse and its general decline in 
numbers throughout Britain is linked to the considerable losses of birch and hazel scrub caused by burning, grazing and urban developments since the turn of the century. There did not appear to be much scrub of this type at Exmoor, which is hardly surprising in view of the present burning and grazing regime.

Probably the most effective measure that might be taken to boost the black grouse population would be to foster the establishment of stretches of tall dense heather and scattered blocks of birch/hazel scrub around the edge of the moors. This measure would require an embargo on burning and a big reduction in grazing pressure for probably 20 years or more. One way of perhaps achieving this aim, whilst still taking a crop off the land, might be to establish conifer plantations, possibly 3-5 hectares in size, with species such as Sitka spruce (Picea sitchensis), Norway spruce (Picea abies), or Douglas fir (Pseudotsuga menziesii) which are less susceptible to damage by black game than Scots pine. Heather would grow tall within the fences, so providing dense cover for the birds, and the preferred food might be supplied by encouraging birch and willow scrub to develop around the margins.

\subsubsection{Mer1in}

Like black grouse, merlins have declined in numbers nationally since 1900, with an apparent acceleration of losses from about 1950. Brown (1976) considered various possible causes, including afforestation, pesticides, persecution by gamekeepers, egg collecting and disturbance, but none, either singly or in combination, could entirely account for the decline; he concluded that a detailed ecological study of the bird was urgently needed to try to pinpoint the reasons for the decrease.

The merlin has an exacting requirement for open country, especially heather moorland. A breeding pair needs a very large hunting area. Various estimates (Nethersole-Thompson \& Watson 1974; Brown 1976) suggest 12-20 square kilometres, with a small home range of about 6 square kilometres in orkney. The chief prey include meadow pipits, skylarks, wheatears and stonechats, all plentiful on Exmoor. Brown has calculated that a pair rearing 3 young requires about 450 small birds during the breeding season or 20-40 birds per square kilometre, depending on the size of the merlins' home range.

At Exmoor, the density of potential prey species is high: skylarks and meadow pipits together amount to some 360 birds per square kilometre (Davies \& Jarman 1978), about 10 times the merlins' needs. The most apparent deficiency in the habitat is a lack of space. Against the need of each pair of merlins for 12-20 square kilometres, the total area of heather moor in the northern region is no more than about $60 \mathrm{~km}^{2}$ whereas it is less than $40 \mathrm{~km}^{2}$ in the south (Table 3.5). Moreover, the heathery areas are fragmented into small blocks, particularly in the south, and these often include large stretches of vegetation dominated by grasses, bracken or gorse. It is perhaps surprising that as many as 4 pairs of merlins attempted to breed on Exmoor in 1978.

The future survival of the merlin on Exmoor cannot be assured. Apart from the obvious and sudden losses of their heather moor habitat due to agricultural improvements, there is evidence of a replacement of heather by indigenous grasses and bracken (Section 6.2.2). The intensive wardening of nesting merlins can no doubt ensure that some young are reared whenever the birds choose to breed. However, in the longer term, their continued 
listing as a breeding species on Exmoor probably depends on there being a halt to the wastage of heather-dominant vegetation.

\subsection{Other birds}

Exmoor has a particularly rich avifauna, probably because of the diversity of habitats and long boundaries between different vegetation types af forded by the interdigitation of heather moorland, gorse and hawthorn scrub, indigenous grassland, seeded grassland, arable land, woodland, and coastal cliffs. Thus, the general pattern of land use and management practices within the National Park supports as great a diversity of bird life as anywhere in south-west England.

Within the moorland area itself and remote. frow woodlands, the greatest range of bird species is found in stretches of gorse scrub, especially on Anstey Common. Gorse was several times described to us as a pernicious weed which had been spreading rapidly in recent years. It can certainly be invasive and there may be a need for control (Section 6.2.1.2). However, gorse adds an element of structural diversity and cover for birds in otherwise uniform tracts of moorland. Moreover, these evergreen shrubs harbour a wide variety of invertebrates throughout the year and are ideal habitat for insectivorous passerines (Bibby 1978). The wholesale clearance of gorse scrub may therefore reduce the species diversity and overall density of birds.

At the other extreme, the central grass moors support only a restricted range of bird species. It might be argued that the rigorous programme of annual burning that is pursued in this region destroys the nests of ground-nesting birds and therefore limits the numbers of both species and individuals. This is improbable. Most areas of grass moor occur at about $400 \mathrm{~m}$ altitude, burning ceases by mid-Apri1, and any birds that might have lost their first clutch in a fire will probably nest again. It is much more likely that annual burning restricts species diversity by destroying potential nesting cover for the birds.

Similar $1 y$, on the heather moors, a decrease in the diversity and density of birds might be expected to follow from over-frequent burning, heavy grazing, and the replacement of heather by less structurally diverse and shorter grasses. Such trends are evident on the heather moor regions and conservationists are already concerned about the rarity of the 2 species of grouse and of the merlin. The snipe and the ring ouzel are also rather scarce, but the other species of heather moorland appear to be maintaining their numbers at present (Davies \& Jarman 1978).

\subsection{Possible losses of nutrients}

Some 20 years ago, many ecologists became concerned about a possible loss of nutrients from moorland ecosystems as a result of the repeated burning of vegetation and cropping. of livestock. Inevitably, some nutrients are lost in the smoke of fires or are washed away in drainage water after solution from the ash deposited by burning. Additional losses result from the annual sale of 1ivestock. Several investigators (eg Allen 1964; Crisp 1966; Chapman 1967) compiled tentative balance sheets of losses from burning, grazing and run-off against possible gains from the nutrients present in rainfall. Taking all factors into account, there is convincing evidence, summarized by the Muirburn Working Party (1977), that on Scottish 
moors the input from rainfall may exceed the loss of all nutrients except phosphorus. Chapran (1967), working on Dorset heathland, found a possible depletion of both phosphorus and nitrogen as a result of burning alone.

More.detailed studies of the amount, distribution and fate of nutrients deposited in ash and rainfall are needed to follow on from those of Allen et al. (1969). These workers. found that nutrients released by burning can be retained in the layer of organic matter at the soil surface, the degree of retention depending on the thickness of the layer. However, it is not clear how quickly such nutrients are recycled, or what happens to the nutrients: deposited by rainfall. Yet the case for largely discounting the effects of burning and grazing largely rests on the assumption that this nutrient input is absorbed by the moorland ecosystem.

It is not possible to calculate the possible gains and losses of nutrients on Exmoor's moorlands without further lengthy investigation. However, it should be assumed that burning and grazing are causing a gradual depletion of phosphorus, and possibly of nitrogen also. Such an effect might be dismissed as being of negligible importance because of the predominantly mineral soils derived from relatively easily weathered sedimentary rocks. Nevertheless, the losses could be significant in such areas as the central grass moors and withypool Cominon which are subject to frequent, often annual; burning. Also, much of the soil of Exmoor may have a relatively low content of organic matter, and hence a low absorptive capacity for nutrients. 


\section{ALTERNATIVE MANAGEMENT AND ITS POSSIBLE EFFECTS}

The general consequences of increasing or decreasing pressures on different moorland vegetation types are discussed in 'Upland land use in England and Wales' (ITE 1978). To consider consequences more specifically for Exmoor, however, it is necessary to know the current grazing pressures. There is a widespread belief that the overall stocking rate on the moors is about 2.5 sheep equivalents per hectare during June-0ctober, possibly increasing in certain areas to 6 or 7 sheep equivalents per hectare during July-October (see. Section 3.1). Expressed annually, these rates represent one sheep equivalent per hectare and 2.4 sheep equivalents per hectare, respectively.

We have found no published figures of actual stocking rates on the moors. It seemed that the common grazings might enable us to estimate the potential maximum stocking rates for several different areas. The Park Authority made available to us 1:250 000 maps showing lands in the Somerset part of the Park that are registered, either provisionally or finally, in the Register of Common Land kept. In accordance with the Commons Registration Act 1965, together with particulars of the rights of common. From this Register, we have calculated the theoretical maximum potential stocking rates for these commons (Table 7.1). The figures vary from a suspiciously low 0.3 sheep per hectare for part of Dunkery Hill to the very high value of 22 sheep per hectare for Room Hill (SS 860364). Certainly, the figure of 0.6 sheep per hectare for Winsford Hill is too low to account for the extent of vegetational change we found there (see Figure 6.1). Further, a partial survey of Exmoor farms found that at least 3 farmers claiming rights for Dunkery Hill, 2 for Withypool, and one for Winsford Hill are not listed in the Register (personal communication from Mrs Carol Cray, an MSc student at Exeter University). Thus, the Register does not accurately reflect the actual stocking rates for many of the commons, and most of the estimates derived from it are probably best disregarded. One exception is Withypool Common, for which it is possible to derive an estimated maximum potential annual stocking rate of 2.2-2.5 sheep per hectare from other sources (Bonham-Carter 1968; Sinclair 1968), which compares well with the figure of 2.1 sheep per hectare calculated from the Register.

However, livestock do not distribute themselves uniformly over a moor under free range conditions. In particular, because animals prefer grazing on some kinds of vegetation more than others, seek shelter from exposure, and have particular behavioural characteristics and social interactions, the effective grazing pressures on a moor vary widely from place to place.

Thus, on Moor House National Nature Reserve, an area of 3850 ha in the Pennines, the mean density of free-ranging sheep on different vegetation types varied from 0.12 sheep per hectare on heathery bog to 4.5 sheep per hectare on bent/fescue grasslands, a 40-fold difference (Rawes \& Welch 1969). On particular sites, sheep density on the bog was as low as 0.01 sheep per hectare (Welch 1968), a remarkable 1300-fold difference! However, while this vividly illustrates the very great variations in animal density that can occur from one patch of vegetation to another on a moor, it is an extreme example. Probably much more akin to the situation on Exmoor was that found on Prignant Hill, lying at 270-400 m altitude in north Cardiganshire (Boulet 1939). There the bent/fescue grasslands carried, on average, twice as many sheep per unit area as swards in which 
Table 7.1 Areas and grazing rights of land in the Somerset part of Exmoor National Park registered, either provisionally or finally, in the Register of Common Land

Site

Dunkery Hill (Cutcombe)

Dunkery Hill

(Wooton Courtenay)

North-east Dunkery Hill (Wooton Courtenay)

Bye Common (Winsford)

Winsford Hi11, Drayton

Knapp, Varle Hill

and Ashway Side

Withypool Common

Little Hill and Exford Common

The Benjamy (The Chains)

Room Hill (Winsford)
291

360

24

73

648

757

85

65

162

2.5

45

1000
Theoretical maximum permissible stocking Grazing rights rates (sheep equi(sheep equivalent/ valent/ha on a year) yearly basis 
heather was predominant. Another example was found on part of the Hil1 Farming Research Organisation!'s Sourhope. Farm, lying at 305-526 m in south-east Scotland, where bent/fescue grasslands attracted almost 3 times the sheep numbers per unit area of heather swards (Hunter 1962).

We do not know how sheep or other livestock distribute themselves on different moors on Exmoor in relation to bent/fescue grasslands and heather swards. In the absence of hard evidence, however, it is reasonable to assume constant relative densities of $2: 1$ or $3: 1$, and to examine how these influence actual stocking rates from place to place, given different proportions of grassland and heather. Effective stocking rates are estimated (Figure 7.1 ), given from $1 \%$ to $99 \%$ of grassland on the moor, overall stocking rates of 1,2 and 3 sheep per hectare, and relative densities of $2: 1$ and $3: 1$. The effective stocking rate on the heather, $\mathrm{S}_{\mathrm{h}}$, can be calculated from the equation:

$$
S_{h}=\frac{S_{o}}{P_{h}+\left(r P_{g}\right)}
$$

Where $S_{o}$ is the overall stocking rate, $P_{h}$ the proportion of heather on the moor, $\mathrm{P}_{\mathrm{g}}$ the proportion of grassland, and $\mathrm{r}$ the relative density factor. Figure 9.1 shows very clearly how the stocking rates on grassland $r$ ise sharply as the proportion of grassland present on the moor decreases. With an overall stocking rate of one sheep per hectare, the estimated actual stocking rate on grassland forming only $5 \%$ of the vegetation rises to 1.9 sheep per hectare with $2: 1$ relative density, and to 2.7 with $3: 1$ relative density. With an overall stocking rate of 3 sheep per hectare, these figures increase to 5.4 and 7.5 sheep per hectare respectively. Figure 7.1 also shows that these differences are additive, ie at an overall stocking rate of 2 sheep per hectare, the effective stocking rate for any given proportion of grassland and any relative density is exactly twice that with an overall stocking rate of one sheep per hectare, and for 3 sheep per hectare overall is 3 times that with one sheep per hectare overal1.

Clearly, local stocking rates on Exmoor may be far higher than the stocking level might suggest. The critical stocking rate above which heather tends to give way to bent/fescue grassland is probably about 2.5 sheep per hectare (ITE 1978). With an average heather moorland stocking rate of one sheep per hectare, this figure is not reached in Figure 7.1 with relative densities of $2: 1$, but at $3: 1$ may be achieved on grassland where this forms only $10 \%$ of the moor, and be exceeded for lesser proportions. If summer grazing levels are high enough to be equivalent to 2.4 sheep per hectare for the year, as apparently happens on some moors (see Section 3.1), then this threshold is reached on almost any grassland within the moor.

The relative sheep densities on bent/fescue grassland compared with heather swards on Exnoor of $2: 1$ or $3: 1$ are obviously estimates. It is unlikely that these densities will remain constant with variations in the relative proportions of different vegetation types from moor to moor. The previous paragraphs, however, give an indication, in the absence of $\mathrm{firm}$ data, of the extent to which local stocking rates are likely to vary with particular average stocking rates. The relative densities of $2: 1$ and $3: 1$ may indeed be an underestimate. Sheep eat heather mainly in winter, but on Exmoor sheep graze on the moors mainly in summer, when they naturally tend to concentrate on grasslands. The ratios of $2: 1$ and $3: 1$ were 
Figure 7.1 Graphs showing how the effective stocking rates on patches of bent/fescue grassland within heather moorland will vary as the proportion of grassland changes, given overall stocking rates of 1,2 and 3 sheep per hectare, and assuming that the sheep concentrations on the grassland are at fixed relative levels of either twice (continuous line) or 3 times (dotted line) those on the heather sward

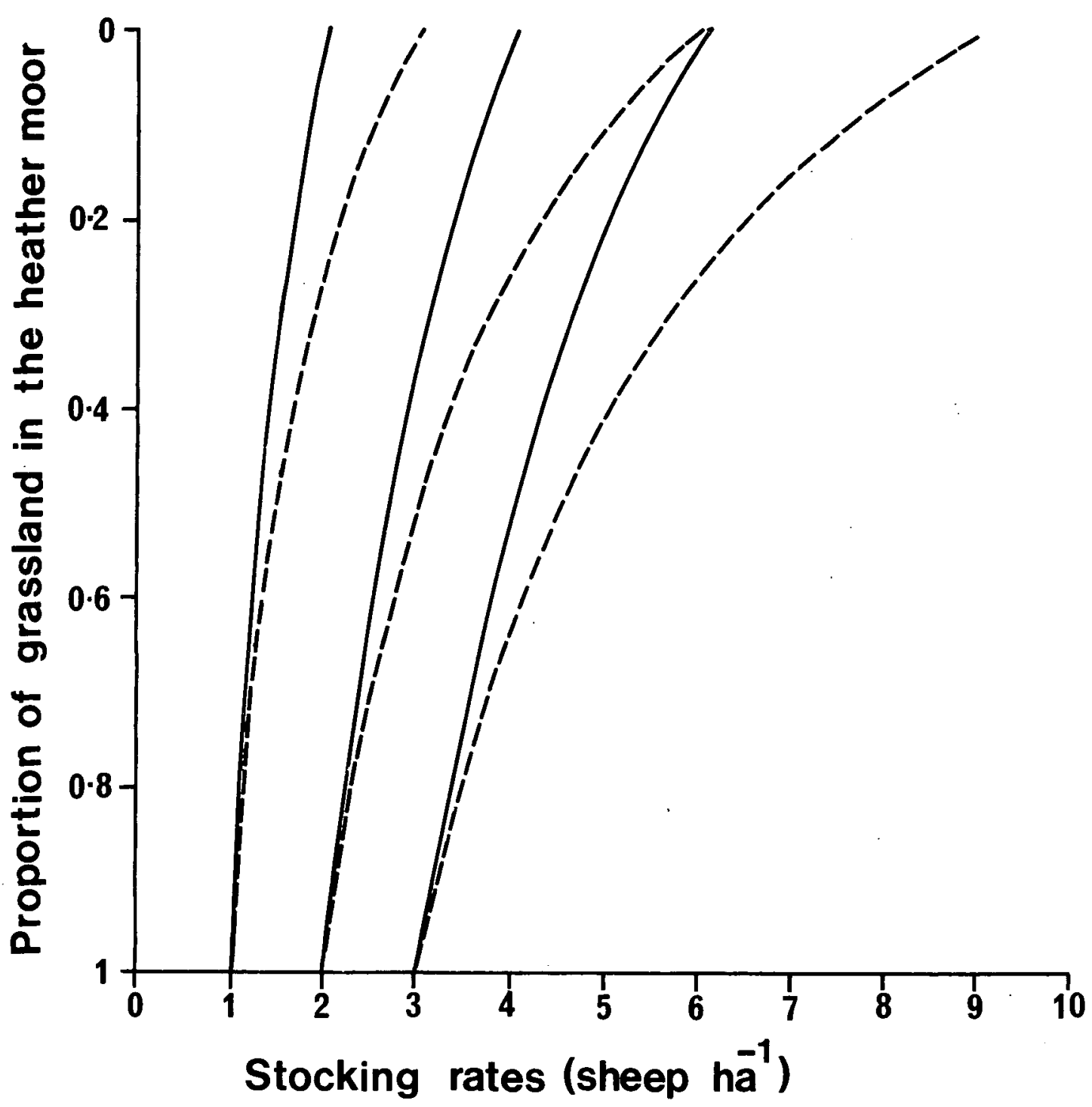


obtained from areas where sheep were grazing all year round. Thus, the actual ratios on Exmoor may be $4: 1$ or greater!

The importance of this argument is that, when sheep are concentrated on patches of grassland surrounded by heather, they inevitably graze at probably rather similar levels, and certainly at higher levels than would otherwise occur, on the heather immediately surrounding the grassy patch. If the grazing pressure on the grassland exceeds the threshold value for persistence of heather, the surrounding heather is gradually killed, and the grassland patch expands (Nicholson 1970; Grant et a1. 1978). Thus, wherever stocking levels reach about 2 sheep per hectare for the year, it is likely that heather is being grazed out locally in many smal1 strips and patches over a moor. On heather moors, this grazing out will happen especially near the margins, where zones of non-heathery vegetation are so frequently found on Exmoor (see Section 6.2 and Appendix 6).

\subsection{Intensification of grazing pressure}

In 'Upland land use in England and Wales' (ITE 1978), the effects of increasing grazing pressures on upland vegetation were reviewed. A series of generalized diagrams were constructed to give the best available estimates of the grazing pressures causing particular changes and the probable timescales involved. It should be stressed, however, that these generalizations were in effect hypotheses; the factual evidence was patchy and their general applicability unknown. Despite this reservation, they are still the best available guidelines for making predictions about particular situations.

Figure 7.2 presents the relationships that seem most applicable to Exmoor. The only trend of current significance is that from predominant heather to bent/fescue grassland. However, if current grazing pressures were increased by $50 \%$ from an apparent average of one sheep per hectare overall on most moors, reaching 2.5 sheep per hectare overall on a few moors, to 1.5 and 3.75 sheep per hectare respectively, then greatly accelerated rates of vegetation change could be expected. Interpolation in Figure 7.1 shows that, with 1.5 sheep per hectare overall on a moor, effective local densities may reach values of $3-4$ sheep per hectare on bent/fescue gxasslands, while with 3.75 sheep per hectare overall these may reach 7-10 sheep per hectare. In the former case, it is clear that heather on the margins of patches of bent/fescue grassland or similar preferred vegetation will inevitably give way to herbaceous vegetation, though the gxassland patch may expand only at a rate of a metre or so per year. If the heather were burnt, however, it would probably be grazed out at a much faster rate, as young heather attracts a greater concentration of animals than older, more woody stands. With an overall stocking rate of 3.75 sheep per hectare, changes at the margins of heather swards are likely to be more rapid. Local concentrations of perhaps 7 and 10 sheep per hectare might cause the heather margins to contract at an average rate of several metres per year, and will locally cause an overall trend to bent/fescue grassland. Burnt heather subjected to such stocking rates would almost certainly never regenerate, but pass in 2-3 years into a grass sward. On acid soils, patches of grassland might locally become overgrazed, tending to a predominance of mosses. On more base-rich soils and on night-bedding grounds, there would be a tendency for ineadow-grass (Poa spp.) to invade, with fescues in particular decreasing. 


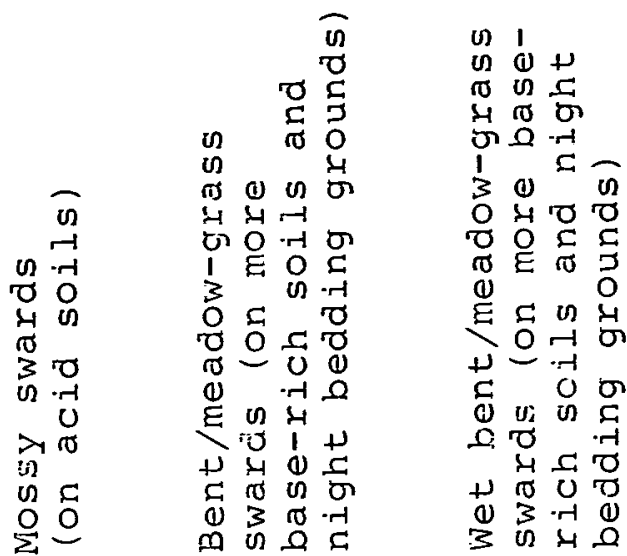
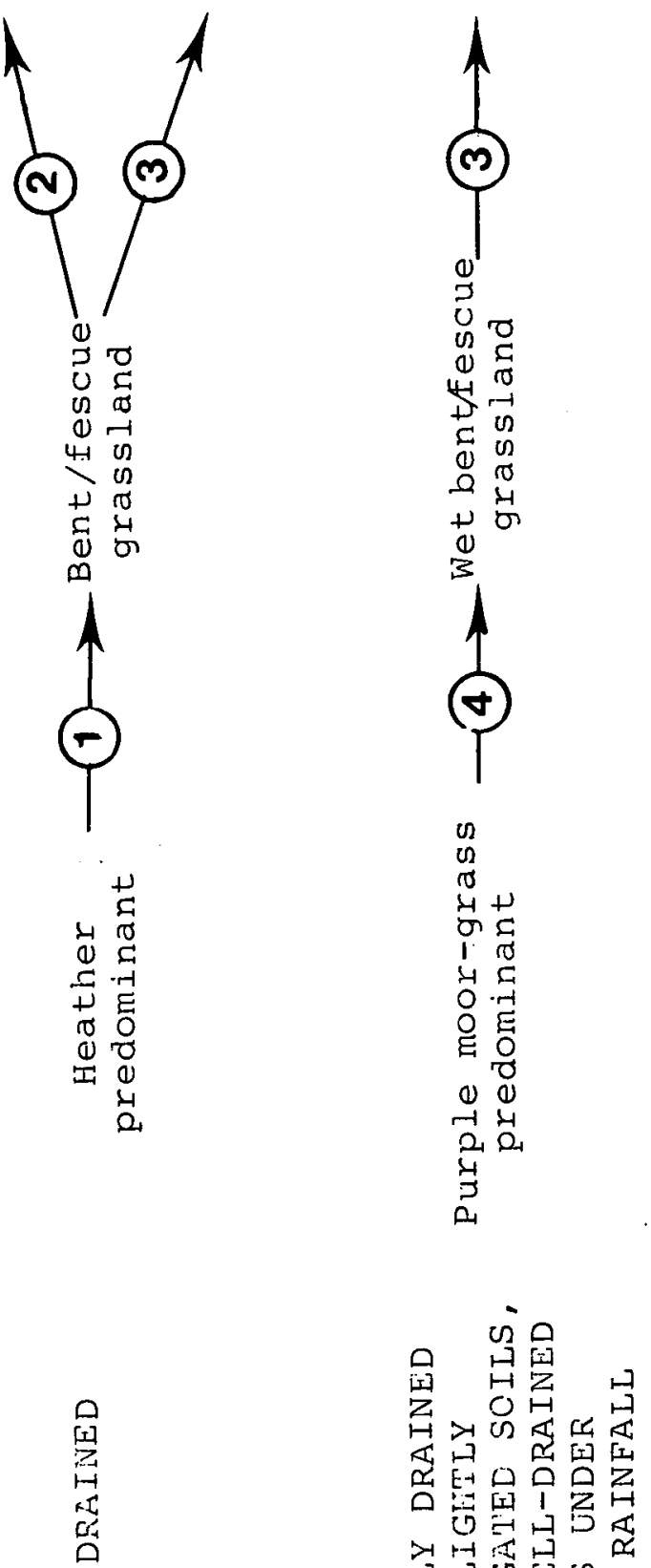

$\begin{array}{ll}0 & 0 \\ 4 & 4 \\ 7 & 4\end{array}$

苗

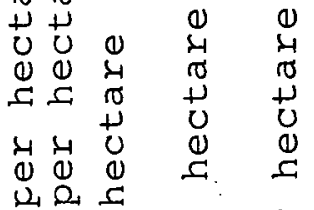

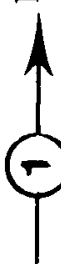

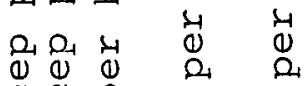

至 0 व

$Y$
$N$
0
0
0
0
01
$|x|$

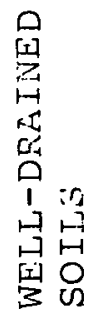

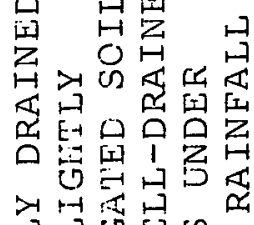

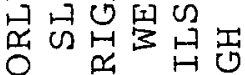

员舟品品出

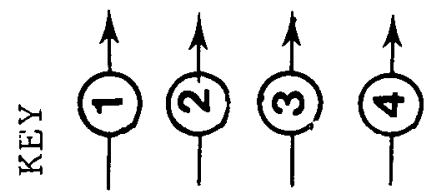


The studies quoted earlier on variations in voluntary stocking rates by free-ranging sheep in different vegetation types suggest that the grass moors are likely to show very similar. local variations in effective stocking rates to the heather moors, with patches of bent/fescue grassland attracting densities 2-3 times those of swards in which purple moor-grass predominates. Increasing overall stocking rates by $50 \%$ would similarly cause trends to increasing spread of bent/fescue swards, while, at 3.75 sheep per hectare overall, these trends might become more widespread. Locally, meadow-grass species might also become more abundant.

It is not clear how such higher stocking rates, and therefore higher rates of grazing, trampling, dunging and urination, would affect potentially invasive species like bracken, rushes, gorse and rhododendron. Substantially higher trampling pressures might encourage the spread of the 3 latter species by producing suitable seed beds, and also by exposing buried seeds to conditions suitable for germination and establishment in the case of the rushes and gorse. Rushes and rhododendron seem relatively unpalatable to livestock, and may still thrive under relatively high grazing pressures. Gorse certainly is grazed by many kinds of animal. High grazing pressures might prevent the formation of dense thickets, but permit the spread of low, cushion-shaped bushes resembling dwarf furze in form. Bracken might also spread with increased grazing pressures, if grazing were by sheep rather than by cattle or ponies which can control bracken by trampling fronds. Sparse bracken in heather might well increase if the higher grazing pressures reduced the vigour of the heather, and thus its competitive ability.

In contrast to sheep, increased grazing by cattle, and probably also by ponies, would tend to reduce the frond density of existing bracken stands and prevent their further spread.

The previous discussions are obviously largely theoretical, based on the application of possible variations in local stocking rates to hypotheses of successional relationships. There is a profound lack of factual information on these matters for Exmoor, as on many other moorlands. It is indisputable, however, that the heather moors on Exmoor are high1y susceptible to increases in grazing pressure, perhaps more so than for most heather moors elsewhere. This is because other species, in particular purple moor-grass and the component grasses and forbs of bent/fescue grassland, are fairly ubiquitous even in the swards with dominant heather and other dwarf shrubs. Estimates from $R$ Williams' survey given in Table 7.2 suggest that on the coastal heaths, northern heather moors and southern heather moors only $34 \%, 21 \%$ and $15 \%$ respectively of the total areas of dwarf shrub heaths are without significant cover of other important species (defined as less than $5 \%$ cover of purple moor-grass or of bent/fescue grassland species collectively, or less than $20 \%$ cover of bracken). In contrast, $48 \%, 57 \%$ and $68 \%$ of the 3 regions respectively contain more than $20 \%$ cover of important species, and $17 \%, 22 \%$ and $17 \%$ respectively from 5 to $20 \%$ cover of these species. In particular, $59 \%, 51 \%$ and $37 \%$ respectively contain more than $5 \%$ cover of bent/fescue grassland species, and so are especially liable to change towards bent/fescue grassland with increasing grazing pressures.

Grazing shortens vegetation and so destroys cover for birds and small mammals. Thus, increasing grazing pressures would decrease the populations of small birds and further decrease the already precarious populations of red and black grouse. Effects on red deer are unlikely, as 
Table 7.2 Relative proportions of different kinds of dwarf shrub-dominated vegetation, expressed as a proportion of their total area, in the 3 main heather moorland regions of Exmoor (figures calculated from Appendix 4)

Dwarf shrubs dominant without significant

Northern
heather
moors

Southern

Coastal

heaths

17

22

13

with 5-20\% cover by bent/fescue grassland species

Dwarf shrubs dominant with $>20 \%$ cover by bent/fescue grassland species

42

29

24

Dwarf shrubs dominant with 5-20\% cover by purple moor-grass

Dwarf shrubs dominant with $>20 \%$ cover by 3

26 36 purple moor-grass

Dwarf shrubs dominant with $>20 \%$ cover by bracken heather moors

5 
they do not seem to rely on the moors for food. Some of the rarer moorland vascular plants might disappear.

\subsection{Introduction of controlled rotational burning of heather}

The present burning regime on Exmoor's heather moors was considered in Section 3.4.1. We concluded that, for several reasons, burning was largely promiscuous and little attempt was made to regulate the size of individual fires. The desirability of planning and control was emphasized in Section 5.2.2, where we also outlined procedures for deciding on the correct rotation (ie the frequency of fires) and discussed the need to limit the size of individual fires. Assuming all obstacles to the effective planning and regulation of fires on Exmoor could be overcome, what effects would controlled, rotational burning have on wildlife?

The main need for responsible burning is to halt the replacement of heather by grasses and bracken. In some places, eg parts of Withypool Common, the heather may be too sparse or too senescent to respond markedly to management. However, there remain many areas, especially on the northern heather moors, where careful burning could perpetuate the heather's existing dominance almost indefinitely, or could so invigorate it as to cause the suppression of competitors.

Planned rotational burning generally encourages a monoculture of heather, and, consequent1y, a loss of floristic diversity. Thus, Gimingham (1964) found 13-17 species of vascular plants, bryophytes and lichens per 4 square metres of regularly burnt heather moor, but 23-24 species in unburnt areas. Such losses may be immaterial as far as the more common and widespread species are concerned, but some of the rarities listed in Table 2.3 could be lost from the Exmoor flora. In this respect, stag'shorn clubmoss, lesser twayblade and crowberry (Empetrum nigrum), all at the southern limit of their ranges and allegedly represented by only a few plants growing amongst heather, could: be specially vulnerable. Nevertheless, the probability of their loss might be no greater than it is under the current regime of haphazard burning.

There is experimental evidence that red grouse breeding stocks increase in response to the controlled burning of patches and strips, but that such burning must be continued year-by-year if stocks are to remain high (Miller et al. 1970). It is probable that grouse numbers might similarly increase if mosaics of short and tall heather were created over a wide area of the northern heather moors. The extent to which the population might increase is a matter for conjecture, but densities in excess of one breeding pair per 5-10 ha may be unlikely because of emigration (Section $6 \cdot 4 \cdot 1)$.

The effect of regular burning on other wild animals is less certain. It would probably have no effect, or perhaps even a negative effect, on numbers of black grouse: their requirements might be better served by tall dense heather and birch/hazel/willow scrub (something that might come from a cessation of burning) rather than by patchworks of tall and short heather. Merlins would presumably benefit in so far as their heather-clad habitat would be stabilized. Recent research in western Ireland suggests that some other species might benefit from increases of heather at the expense of purple moor-grass. Thus, meadow pipits were found to be more abundant on heather-dominated ground than on surrounding bogland containing mainly purple moor-grass (Watson \& O'Hare 1979a). Also in 
western Ireland, A $N$ Lance (unpublished) showed experimentally that strip-burnt vegetation with heather and purple moor-grass co-dominant consistently supported higher populations of skylarks and meadow pipits than adjacent unburnt vegetation. Lance attributed this difference to the burnt ground having a more varied invertebrate fauna.

It is only in the last few years that any attempt has been made to quantify the effects of burning on animal species other than red grouse. Preliminary results suggest that burning might have far-reaching effects, but more data are required before any synthesis can be attempted.

There remains the question of the effect of controlled rotational burning on the performance of sheep. One Irish experiment (Lance \& Triggs 1974) suggests that sheep with access to patchwork-burnt heather show (i) less winter mortality amongst ewes, (ii) better lambing percentages, and (iii) better rates of live welght gain by lambs than do sheep on unburnt ground. Although these are interesting trends, the experiment requires repetition with more rigorous control. Unfortunately, this appears to be the only attempt made to evaluate the effects of heather burning on sheep per formance.

Therefore, we can on1y speculate about how Exmoor's sheep might respond to rotational heather burning on the basis of our understanding of the farming system there, the animals' grazing preferences, and the probable nutritive value of the vegetation. All indications are that the introduction of controlled burning would have little overall effect on livestock production, perhaps even none at all. This conclusion derives from 4 facts: ( $i$ ) the moorland is used primarily as summer grazing, (ii) there are large amounts of grass (more than $20 \%$ by area) on the heather moors, (iii) heather is inferlor to grass in feeding value during summer, and (iv) sheep prefer to eat grass rather than heather during summer.

Patchwork burning might encourage sheep to range widely over the moorland area because of the easy access afforded by strips of short vegetation. It might also provide additional supplies of grass if bristle bent or other species became temporarily abundant during the early stages of the succession after fire. To that extent, the burning could benefit summer-grazed sheep. However, unless the stocking rate was raised, they would be unlikely to ingest appreciably more heather than they do now and, even if they did, it would be of dubious feeding value.

The few sheep that are grazed on the moor over winter may fare better because they probably consume significant amounts of heather. The shoots of young heather contain appreclably higher concentrations of nutrients than older shoots (Miller 1979), and it is well established that sheep prefer to graze on young rather than old heather patches (Grant \& Hunter 1968a). Thus, winter-grazed sheep would probably benefit nutritionally from controlled heather burning, as Lance and Triggs' sheep apparently benefitted. Possibly more of the hardier, though less productive, breeds of sheep could be carried on the heather moors over winter, if the burning were properly planned. However, the provision of housing and the increased conservation of summer grass might be more efficient ways of raising the capacity to over-winter sheep.

Two variations on the usual burning programme for heather nay be of value in certain circumstances on Exmoor, although their effects need to be tested experimenta11y. First, burning in auturan may have some advantage through better regeneration of heather (Section 5.1.2), and is possibly 
applicable to areas where the heather is sparse or degenerate. It is not known whether autumn burning will have greater or lesser success in the suppression of invasive species such as bracken and purple moor-grass. Second, the cutting and removal of old heather (Section 5.2.3), is technically feasible as an alternative to burning and can produce the same short-term response by the vegetation, although the long-term response is uncertain. Cutting is expensive but may be applicable locally where maintenance of heather cover is particularly important and burning is impossible because of weather conditions or certain site characteristics.

\subsection{Decrease in grazing pressures and burning frequency}

Figure 7.3 presents the successional relationships that seem most applicable to Exmoor. It is not known how fast these different trends would progress under different grazing pressures and burning frequencies. The estimates in Figure 7.3 assume no grazing by domestic livestock and no burning.

On the heather moors, the main trend will be towards colonization by shrubs and trees. If there is a nearby seed source, some establishment of wind-dispersed species like birch and willow will probably occur immediately, as will some establishment in a more scattered manner of bird-dispersed species like hawthorn (see Plates 8 and 11) and rowan (see Plate 12). Most trees and shrubs will establish falrly freely during the early pioneer and degenerate phases of heather, and relatively poorly or not at all during the bullding and mature phases. This simply reflects the absence of suitable niches when the heather canopy is closed (Miles \& Kinnaird 1979). With the relatively fertile soils generally found on Exmoor, tree growth will probably be rapid, at least in the less exposed places, leading to early flowering and seed production, with a consequent increase in the seed rain elsewhere. On small patches of moorland with substantial seed sources nearby, like Haddon Hill, it is easy to envisage the entire moor giving way to scrub in 25 years or so. Similarly, larger areas adjacent to good seed sources, like parts of Winsford Hill and the northern edge of Dunkery Hill, are equally liable to suffer rapid scrub invasion. Over most of the larger areas, however, like Withypool Common, Brendon Common and Dunkery Hill, it is difficult to envisage a predominant scrub cover forming even within the next 100 years. Probab1y, 150-200 years would be needed. Factors governing the spread of particular species are discussed in more detail by Miles and Kinnaird (1979).

On the grass moors, the successional changes are likely to be slightly more complex. Where a substantial seed source exists, scrub may invade for the first few years after grazing by livestock is stopped, until the grassland forms such a. dense, matted sward that few or no niches are available. As individual grass tussocks of many species age, however, they tend to die off from the centre, and thus to produce bare patches suitable for seedling establishment. The intervening, very dense canopy phase may last for 5-15 years or longer.

If dwarf shrubs are present at the time grazing ceases, they can grow quickly and dominate the sward. Bilberry can spread vigorously by underground stems, and may attain temporary doninance, or co-dominance with heather, but eventually it is likely to give way to heather predominance, unless succession to scrub occurs first. Swards with predominant purple moor-grass are likely to show changes similar to those of bent/fescue grasslands though, until succession to dwarf shrub heath or 
Figure 7.3 Likely successional changes with negligible grazing pressure and no burning

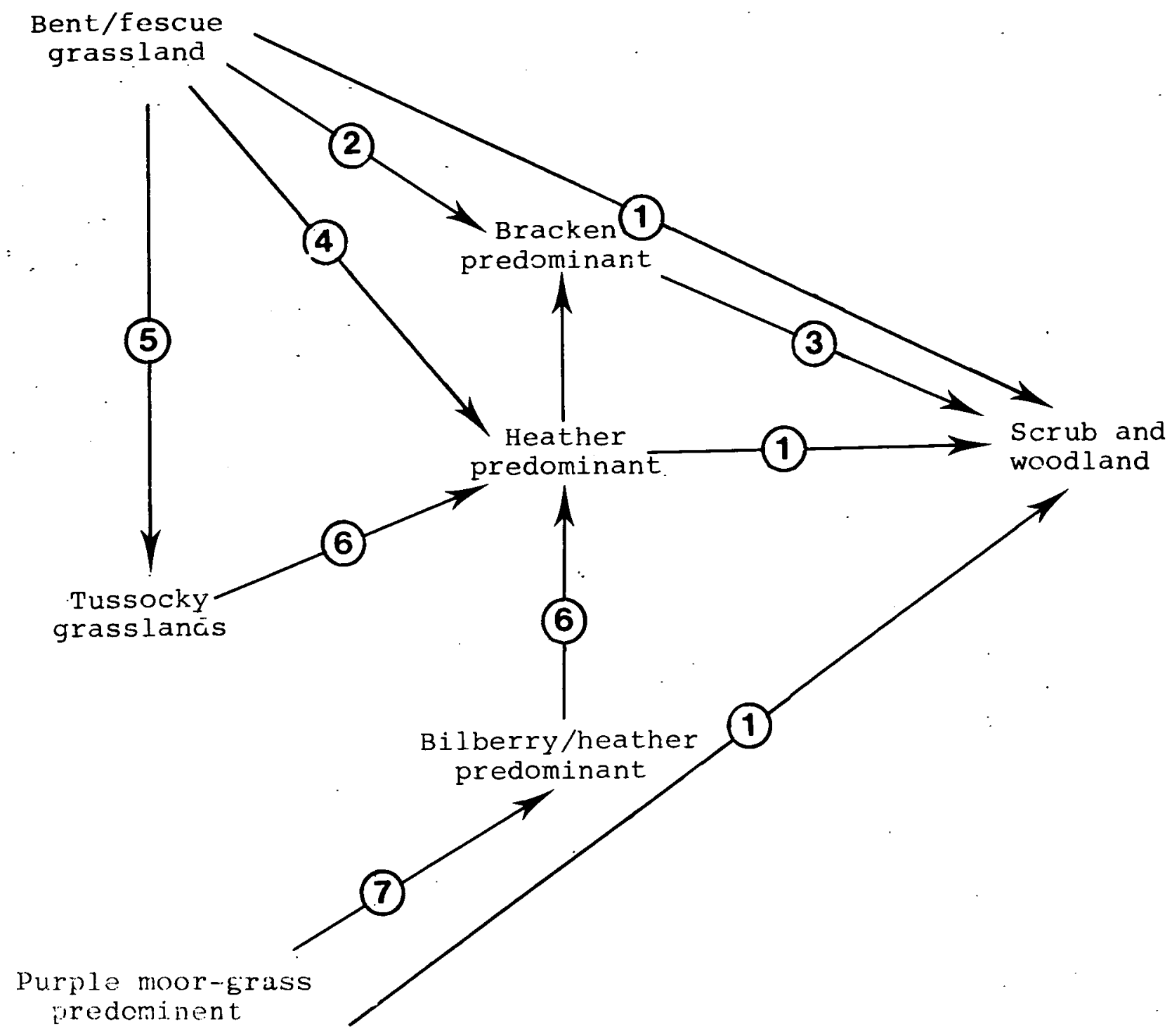

KEY

1 (1) Time $10-50+$ years

(2) $\rightarrow$ A bracken front may invade at $20-40+\mathrm{cm}$ per year

(3) $\rightarrow$ Timescale for invasion by trees unknown; might be centuries

(4) $\rightarrow$ Time 5+ years if grazed-down heatier plants present; sequence otherwise unlikely

-5) $\rightarrow$ Time 5 -15 years if no invasion by bracken or woody species

$\rightarrow$ Time $10-50+$ years

(7) $\rightarrow$ Time $20-50+$ years 
scrub takes place, the purple moor-grass will tend to further increase its abundance at the expense of most other grasses.

Large expanses of the grass moors are almost free of dwarf shrubs, but it is very noticeable that the roadside walls, banks and verges within this region commonly bear dense stands of bilberry and heather (see plates 3 and 4). These provide a substantial local seed source, and under low grazing pressures would act as foci for spread. Bilberry seed is bird-dispersed, and new plants might eventually appear widely scattered over the moors. Heather seed is wind-dispersed, with an effective range of at least $100 \mathrm{~m}$, so that pronounced marginal incursions would probably occur within 20 or 50 years. However, because of the large area involved, and the paucity of dwarf shrubs in many parts, it is unlikely that the grass moors would substantially change to dwarf shrub heath or heather moorland in less than about 100 years. Eventual change to scrub and woodland might take even longer than on the larger heather moors.

Locally, there are a few small patches of heather noor where trees and shrubs are currently becoming established (Plate 12). It is not known what grazing pressures permit this establishment. In one forest in north-east Scotland, it was estimated that a winter density of red deer of less than one deer per 25 ha was needed for regeneration of birch, Scots pine and larch (Larix decidua) (Holloway 1967), which is equivalent to about 0.1 sheep per ha. On the other hand, it has been estimated for the New Forest that densities of less than one cow per 1-2 ha, one deer per 3-4 ha, or one pony per 5-7 ha would permit tree regeneration. In sheep equivalents, these densities vary from 5 sheep per ha to about 0.6 per ha. The upper densities are surprisingly high and would almost certainly not permit tree establishment on open moorland. However, with current estimated average stocking rates of one sheep per ha over the year, effective stocking levels on open heather moorland may average only 0.6-0.8 sheep per ha, and may be even lower locally. Any substantial reduction of overall stocking rates from current levels might thus permit more widespread colonization of the moors by trees and shrubs, assuming that fires were prevented.

There are also many small patches of grass moor where heather is present in heavily grazed prostrate form. Preventing the approximately annual burning of these areas, would probably permit such heather to grow up and eventually become dominant, if the existing plants are dense enough; 2-3 plants per square metre might be sufficient. Where current grazing pressures would prevent such growth of heather even in the absence of burning, any reduction of effective stocking rates below about 2.5 sheep per ha would enable the heather to grow Into bush form.

Decreasing grazing and burning would have the opposite effects on bird populations of increases in these factors (see Section 7.1 and 7.2). Thus, as vegetation grew up and cover increased, populations of small birds would also increase and, if sufficient scrub grew, black grouse might also increase in number. On the other hand, red grouse numbers would decrease.

\subsection{Application of fertilizers}

It has been suggested that applying fertilizers to the moorlands might permit greater utilization of the moorland vegetation by livestock, and thereby partly counter the economic pressures for converting moorland into 
productive grassland. Application of fertilizers would certainly increase herbage production, and probably its digestibility. If it is desired to maintain the present characteristic moorland vegetation, however, fertilizing would be a mistake. The addition of fertilizers to any vegetation causes change; the greater the application rates, the faster and more profound the changes will be. Under free range conditions, animals will tend to concentrate at any fertilized patches of heather moorland, which will then be subjected to greatly increased grazing pressures compared with unfertilized patches. Under such conditions, heather and bilberry will tend to disappear and be replaced by grasses (Jones 1967). Even with low grazing pressures, heather may tend to be replaced by grasses, especially purple moor-grass. If only lime and/or basic slag were applied, changes would be slower but would inexorably follow. As pointed out in section 5.2.4, the only real case for applying fertilizers to moorland is as a means of causing dwarf shrubs like heather to be replaced by grasses. In any case, there is little point in improving moorland for summer grazing because there is already an excess of herbage available at that time. Arguably, fertilizers are better used to improve the production of conserved forage on inbye land for wintering sheep.

\subsection{Landscape management}

The term 'landscape management' is used here to denote the whole range of management and technical procedures which can be used to maintain or produce any form of vegetation that is required to preserve or enhance the natural beauty of an area. An alternative term, 'conservation farming', emphasizes that much of the control of vegetation is in the hands of the farmers and land owners, who influence landscape on a large scale. Overt landscape management for conservation reasons has been mainly smal1-scale and intensive, but it is likely that National Park Authorities and other conservation organizations will increasingly take practical steps to control the vegetation component of the landscape in amentty areas. objections to the judicious management of areas valued for their 'natural beauty', on the grounds that the vegetation is natural, are invalid. The vegetation of Exmoor, and of other National Parks, has been modified by man, directly and indirectly, deliberately and inadvertently, for several thousands of years. Just as farmers and foresters exercise careful control over the vegetation which they manage for spectfic purposes, so those responsible for the landscape can take parallel action. Frequently, it will be necessary only to ensure the continuation of existing management practices, but there needs to be a reasoned and explicit management plan. Where the vegetation is changing in a manner considered to be undesirable, specific management procedures should be introduced and the results carefully monitored. The heather moor on Exmoor is probably a case where specific landscape management is necessary for its conservation.

The techniques for landscape management have been discussed above - the control of burning and grazing regimes, the use of fertilizers, herbicides and mechanical treatments such as cutting. Direct seeding may be necessary to regenerate heather in some areas on Exmoor: it has been done on an experimental scale in a mixed heather/purple moor-grass sward in Scotland, the moor-grass being killed by spraying with dalapon before seeding. Details of small-scale use of many of these management practices are given in the study of the 'Management of grassland and heathland in Country Parks' (Lowday \& Wells 1977). 


\section{FUTURE WORK}

In recent years, the management of Exmoor's moorlands has stimulated interest and controversy amongst a variety of public bodies and private individuals. Most discussion has focused on the immediate conversions of semi-natural moorland vegetation into sown grassland. Nevertheless, there are other, slower, less spectacular, but nonetheless systematic changes taking place. These involve the replacement of one vegetation type by another in response to pressures exerted by the past and present grazing and burning regimes.

Our investigation has indicated certain deficiencies of knowledge about the soils, vegetation and animal life of Exmoor. The most serious of these relate to the management of the vegetation; there is a lack of detailed information about (i) the current stocking rates of sheep, cattle and horses on the moors, (ii) burning frequencies, and (iii) the direction and speed of successional changes in the vegetation. It is quite feasible to direct successions towards desired ends, but only if their cause, nature, rate and reversibility are fully understood. The following proposals for further work have been formulated with this aim in mind.

i. Assess changes in the vegetation since 1947, using the repeated aerial photographic surveys of Exmoor during the last 32 years.

ii. Record future changes in the vegetation using vegetation maps, permanent quadrats and photographic records.

iii. Investigate the utilization of the vegetation by herbivores by direct field observation and a questionnaire survey amongst farmers.

iv. Measure experimentally the rates of change in vegetation in response to grazing, burning or other management treatments.

v. Study the population ecology of certain rare or key species, such as merlin or gorse. 


\section{ACKNOULEDGEMENTS}

We have called upon the help of several organizations and individuals in compiling this report. We are particularly grateful to the staff of the Countryside Commission, Exmoor National Park Department, Ministry of Agriculture, Fisheries and Food, Nature Conservancy Council, and Soil Survey of England and Wales, for their willing co-operation in providing information about Exmoor. In addition, we received friendly and valuable assistance from Mr N V Allen and Miss C J Giddens of the Exmoor Natural History Society, Mr $J$ Conchie of the National Farmers' Union, Major $G$ Courage of the National Trust, Mr E T Davies and Mrs C Cray of Exeter University, Mr S Davies of the Royal Society for the Protection of Birds, and $\mathrm{Mr} H$ Thomas and $\mathrm{Mr} \mathrm{R}$ Smith of Fortescue Estate. Special thanks are also due to Miss S Gates, Mr H Geen, Mr A J B Halliday, Mr E R Lloyd, Mr W Pugsley and Sir Dennis Stucley.

Amongst our colleagues in ITE, we appreciate the help and advice given by many, particularly Mr P G Ainsworth, Dr S B Chapman, Mr J Heath, Mr V P W Lowe, Mr P Rothery, Dr J Sheail and Dr A Watson. 
Allen, N.V. 1976. The birds. of Exmoor. 2nd ed. Dulverton: Exmoor Press.

Allen, S.E. 1964. Chemical aspects of heather burning. J. appl. Ecol., $1,347-367$.

Allen, S.E., Evans, C.C. \& Grimshaw, H.M. 1969. The distribution of mineral nutrients in soil after heather burning. 0ikos, 20, 16-25.

Armstrong, D.G. \& Thomas, B. 1953. The nutritive value of Calluna vulgaris. II. A preliminary study of digestibility. J.agric. Sci., Camb., 43, 223-228.

Arnold, G.H. 1964. Some principles in the investigation of selective grazing. Proc. Aust. Soc. Anim. Prod., 5, 258-271.

Ba11, D.F. 1973. The soils of upland Britain. In: The future of upland Britain, edited by R.B. Tranter, 397-416. Reading: Centre for Agricultural strategy, University of Reading.

Bellamy, D.J. \& Holland, P.G. 1966. Determination of the net annual aerial production of Calluna vulgaris (L.) Hull, in northern England. Oikos, 17, 272-275.

Bibby, C.J. 1978. A heathland bird census. Bird Study, 25, 87-96.

Birse, E.L. Dry, F.T. 1970. Assessment of climatic conditions in Scotland. I. Based on accumulated temperature and potential water deficit. Aberdeen: Macaulay Institute for Soil Research.

Black, J.S. 1967. The digestibility of indigenous hill pasture species. Rep. Hill Fmg Res. Org., 4th, 1964-67, 33-37.

Bonham-Carter, V. 1968. Withypool Common: the historical background. Exmoor Rev., 9, 48-53.

Boulet, L.J. 1939. The ecology of a Welsh mountain sheep-wa1k. PhD thesis, University of Wales.

Brown, L. 1976. British birds of prey. (New naturalist no: 60). London: Collins.

Chapman, S.B. 1967. Nutrient budgets for a dry heath ecosystem in the south of England. J. Ecol., 55, 677-689.

Chapman, S.B., Hibble, J. \& Rafarel, C.R. 1975. Net aerial production by Calluna vulgaris on lowland heath in Britain. J. Ecol., 63, 233-258.

Chavasse, C.G.R. \& Davenhi11, N.A. 1973. A review of chemical control of bracken and gorse for forest establishment. Proc. N.Z. Weed Control Conf., no. $26,2-6$.

Crisp, D.T. 1966. Input and output of minerals for an area of Pennine moorland: the importance of precipitation, drainage, erosion and animals. J. appl.Ecol., 3, 327-348.

Cross, J.R. 1975. Biological flora of the British Isles: Rhododendron ponticum L. J. Ecol., 63, 345-364.

Curtis, L.F. 1971. Soils of Exmoor Forest. (Special survey no. 5). Harpenden: Soil Survey of England and Wales.

Davies, E.T. 1977. Aspects of land use in the Exmoor National Park. (Report no. 200). Exeter: Agricultural Economics Unit, University. of Exeter.

Davies, S. \& Jarman, R. 1978. Exmoor moorland ornithological survey. Sandy: Royal. Society for the protection of Birds and Somerset Trust for Nature Conservation. (Unpublished).

Eadie, J. 1971. Hill pastoral resources and sheep production. Proc. Nutr. Soc., 30, 204-210.

Evans, D.F., Hi11, M.O. \& Ward, S.D. 1977. A dichotomous key to British sub-montane plant communities. (Bangor Research Station occasional paper no. 1). Bangor: Institute of Terrestrial Ecology.

Exmoor National Park Committee. 1977. Exmoor National Park Plan. Dulverton: National Park Committee. 
Fryer, J.D. \& Evans, S.A. eds. 1970. Weed control handbook. I. Principles. 5th ed., revised reprint. 0xford: Blackwell Scientific.

Fryer, J.D. \& Makepeace, R.J. eds. 1972. Weed control handbook. II. Recommendations, including plant growth regulations. 7 th ed. 0xford: Blackwell Scientific.

Giddens, C.J. 1977. Flowers of Exmoor: a preliminary check-1ist of vascular plants. Minehead: Exmoor Natural History Society.

Gimingham, C.H. 1949. The effects of grazing on the balance between Erica cinerea L. and Calluna vulgaris (L.) Hull in upland heath, and their mor phological responses. J. Ecol., 37, 100-119.

Gimingham, C.H. 1964. The composition of the vegetation and its balance with environment. Adv. Sci., 21, 148-152.

Gimingham, C.H., Chapman, S.B. \& Hebb, N.R. 1979. European heathlands. In: Heathlands and related shrublands, edited by R.L. Specht, 365-413. Amsterdam: Elsevier.

Gloyne, R.W. 1958. On the growing season. Agric. Mem. Met. Office, no. 18. (Unpub1ished).

Gloyne, R.W. 1968. Some climatic influences affecting hill-land productivity. In: Hill-land productivity, edited by I.V. Hunt, 9-15. (Occasional symposium no. 4). Hurley: British Grassland Society.

Golightly, W.H. 1962. Biological control of Lochmaea suturalis (Thomson) (Co1., Chrysomelidae). Entomologist's mon. Mag., 98, 196.

Grant, S.A. Hunter, R.F. 1966. The effects of frequency and season of clipping on the morphology, productivity and chemical composition of Calluna vulgaris (L.) Hull. New Phytol., 65, 125-133.

Grant, S.A. Hunter, R.F. 1968a. Interactions of grazing and burning on heather moors and their implications in heather management. J. Br. Grassld Soc., 23, 285-293.

Grant, S.A. \& Hunter, R.F. 1968b. Variation in yield, maturity type, winter greenness and sensitivity to cutting of hill grass species. J. Br. Grassld Soc., 23, 149-155.

Grant, S.A. \& Milne, J.A. 1973. Factors affecting the role of heather (Calluna vulgaris (L.) Hu11) in grazing systems. In: Hill pasture improvement and its economic utilization, edited by P.A. Gething, P. Newbould and J.B.E. Patterson, 41-46. Henley-on-Thames: Potassium Institute.

Grant, S.A., Barthram, G.T., Lamb, H.I.C.\& Milne, J.A. 1978. Effects of season and level of grazing on the utilization of heather by sheep. 1. Responses of the sward. J. Br. Grassld Soc., 33, 289-300.

Grant, S.A., Hunter, R.F. \& Cross, C. 1963. The effects of muirburning Molinia-dominant communities. J. Br. Grassld Soc., 18, 249-257.

Grant, S.A., Lamb, W.I.C., Kerr, C.D. \& Bolton, G.R. 1976. The utilization of blanket bog vegetation by grazing sheep. J. appl. Ecol., 13, 857-869.

Hamilton, A, 1907. The red deer of Exmoor. London: Hor ace Cox.

Holloway, C w. 1967. The effects of red deer and other animals on naturally regenerated scots pine. PhD thesis, University of Aberdeen.

Hoskins, W.G. \& Stamp, L.D. 1963. The common lands of England and Wales. (New naturalist no. 45). London: Colilins.

Hunter, R.F. 1962. Hill sheep and their pasture: a study of sheep grazing in south-east Scotland. J. Ecol., 50, 651-680.

Institute of Terrestrial Ecology. 1978. Upland land use in England and Wales. (CCP 111). Cheltenham: Countryside Commission.

Jenkins, D., Watson, A. \& Miller, G.R. 1963. Population studies on red grouse Lagopus lagopus scoticus (Lath.) in north-east Scotland. J. Anim. Ecol., 32, 317-376.

Jenkins, D., Watson, A. \& Miller, G.R. 1964. Predation and red grouse populations. J. appl. Ecol., 1, 183-195. 
Johnstone, G.W. 1967. Blackgame and capercaillie in relation to forestry in Britain. (Wildlife in the forest). Forestry, 40, Suppl., 68-77.

Jones, L.I. 1967. Studies on hill land in Wales. (Tech. Bull. no. 4). Aberystwyth: Welsh Plant Breeding Station.

Jones, W.D. 1978. A review of some aspects of hill and upland farming. In: The future of upland Britain, edited by R.B. Tranter, 50-74. Reading: Centre for Agricultural Strategy, University of Reading.

King, J. \& Davies, G.E. 1963. The effect of dalapon on the species of hill grasslands. J. Br. Grassld Soc., 18, 52-55.

Lance, A.N. \& Triggs, R. 1974. Developing hill bogland to benefit both grouse and sheep. Farm \& Food Res., 5, 135-136.

Linn, I. 1970. The animals of the Park. In: Exmoor National Park, edited by J. Coleman-Cooke, 26-40. (Countryside Commission National Park Guide no. 8). London: HMSO.

Lloyd, E.R. 1975. The wild red deer of Exmoor. 2nd ed. Dulverton: Exmoor Press.

Lowday, J.E. \& Wells, T.C.E. 1977. The management of grassland and heathland in country parks. (CCP 105). Cheltenham: Countryside Commission.

Lowe, V.P.W. \& Gardiner, A.S. 1974. A re-examination of the subspecies of the red deer (Cervus elaphus) with particular reference to the stocks in Britain. J. Zool., 174, 185-201.

McCavish, W.J. 1980. Herbicides for woody weed control by foliar applications. Res. Inf. Note For. Commn, Lond., no. 56.

Macleod, A.C. 1955. Heather in the seasonal dietary of sheep. Proc. Br. Soc. Anim. Prod., 13-17.

McVean, D.N. \& Ratcliffe, D.A. 1962. plant communities of the Scottish Highlands: a study of Scottish mountain, moorland and forest vegetation. (Monographs of the Nature Conservancy no. 1). London: HMSO.

Martin, D.J. 1964. Analysis of sheep diet utilizing plant epidermal fragments in faeces samples. In: Grazing in terrestrial and marine environments, edited by D.J. Crisp, 173-188. Oxford: Blackwe11 Scientific.

Heeklah, F.A. 1967. A comparison of 2,4,5-T and picloram for gorse control. Proc. N.Z. Weed Control Conf., no. 20, 26-31.

Merryfield, D.L. \& Moore, P.D. 1974. Prehistoric human activity and blanket peat initiation on Exmoor. Nature, Lond., 250, 439-441.

Miles, J. 1974a. Experimental establishment of new species from seed in Callunetum in north-east Scotland. J. Ecol., 62, 527-551.

Miles, J. 1974b. Effects of experimental interference with stand structure on establishment of seedlings in Callunetum. J. Ecol., 62, 675-687.

Miles, J. 1979. Vegetation dynamics. (Outline studies in ecology). London: Chapman \& Hall.

Miles, J. 1981. Problems in heathland and grassland dynamics. Vegetatio, 46, 61-74.

Miles, J. \&innaird, J.W. 1979. The establishment and regeneration of birch, juniper and Scots pine in the Scottish Highlands. Scott. For. , 33, 102-119.

Miller, G.R. 1968. Evidence for selective feeding on fertilized plots by red grouse, hares and rabbits. J. Wild1. Mgmt, 32, 849-853.

Miller, G.R. 1971. Grazing and the regeneration of shrubs and trees. In: Range ecology research. 1st progress report, 27-40. Edinburgh: Nature Conservancy.

Miller, G.R. 1979. Quantity and quality of the annual production of shoots and flowers by Calluna vulgaris in north-east Scotland. J. Eco1., 67, 109-129. 
Miller, G.R. \& Miles, J. 1970. Regeneration of heather (Calluna vulgaris (L.) Hul1) at different ages and seasons in north-east Scotland. J. appl. Ecol., 7, 51-60.

Miller, G.R. \& Hatson, A. 1974. Some effects of fire on vertebrate herbivores in the Scottish Highlands. Proc. Ann. Tall Timb. Fire Eco1. Conf., 13, 39-64.

Milier, G.R. \& Watson, A. 1978. Territories and the food plant of individual red grouse. I. Territory size, number of mates and brood size compared with the abundance, production and diversity of heather. J. Anim. Ecol., 47, 293-305.

Miller, G.R., Jenkins, D. Watson, A. 1966. Heather performance and red grouse populations. I. Visual estimates of heather performance. $\mathrm{J}$. app1. Ecol., 3, 313-326.

Miller, G.R., Watson, A. Jenkins, D. 1970. Response of red grouse populations to experimental improvement of their food. In: Animal populations in relation to their food resources, edited by A. Watson, 323-335. Oxford: Blackwell Scientific.

Milne, J.A. 1974. The effects of season and age of stand on the nutritive value of heather (Calluna vulgaris, (L.) Hull) to sheep. J. agric. Sci., Camb., 83, 281-288.

Milne, J.A. \& Grant, S.A. 1978. Better use of heather and hills for sheep production. Rep. Hill Fmg Res. Org., 7th, 1974-77, 41-48.

Milne, J.A., Bagley, L. Grant, S.A. 1979. Effects of season and level of grazing on the utilization of heather by sheep. 2. Diet selection and intake. Grass Forage Sci., 34, 43-51.

Milton, W.E.J. 1948. The buried viable seed content of upland soils in Montgomeryshire. Emp. J. exp. Agric., 16, 163-177.

Ministr.y of Agriculture, Fisheries and Food. 1978. Liscombe Experimental Husbandry Farm Annual Review 1977. Dulverton: Ministry of Agriculture, Fisheries and Food.

Mitche11, B., Staines, B.W. \& Welch, D. 1977. Ecology of red deer: a research review relevant to their management in Scotland. Cambridge: Institute of Terrestrial Ecology.

Mohamed, B.F. \& Gimingham. C.H. 1970. The morphology of vegetative regeneration in Calluna vulgaris. New Phytol., 69, 743-750.

Muirburn Working Party. 1977. A guide to good muirburn practice. Edinburgh: HMSO.

Nethersole-Thompson, D. Watson, A. 1974. The Cairngorms: their natural history and scenery. London: Collins.

Nicholson I.A. 1970. Some effects of animal grazing and browsing on vegetation. Trans. bot. Soc. Edinb., 41, 85-94.

Palmar, C.E. 1968. Blackgame. Forest Rec., Lond., no. 66.

Perring, F.H. Walters, S.M. 1962. Atlas of the British flora. London: Nelson, for the Botanical Society of the British Isles.

Perring, F.H. \& Walters, S.M. 1975. Atlas of the British flora. 2nd ed. Wakefield: EP Publishing.

Picozzi, N. 1968. Grouse bags in relation to the management and geology of heather moors. J. appl. Ecol., 5, 483-488.

Picozzi, N. 1971. Breeding performance and shooting bags of red grouse in relation to public access in the Peak District National Park, England. Biol. Conserv., 3, 211-215.

Pielou, E.C. 1975. Ecological diversity. New York: Wiley.

Porchester, Lord. 1977. A study of Exmoor. London: HMSO.

Preest, D. 1980. Seasonal variation in seedling gorse susceptibility to follar herbicides. Proc. N.Z. Weed Pest Control Conf., no. 33, 165-169.

Rawes, M. \& Welch, D. 1969. Upland productivity of vegetation and sheep at Moor House National Nature Reserve, Westmorland, England. Oikos, Supp1., 11, 1-72. 
Revesz, T. 1969. Climate. In: Exeter and its region, edited by F. Barlow, 43-59. Exeter: University of Exeter.

Richards, P.H. \& Clapham, A.R. 1941. Biological flora of the British Isles: Juncus effusus. J. Eco1., 29, 375-380.

Russe1, A.J.F. \& Eadie, J. 1968. Nutrition of the hill ewe. In: Hi11-land productivity, edited by I.V. Hunt, 184-190. (Occasional symposium no. 4). Hurley: British Grassland Society.

Sharrock, J. 1976. Atlas of breeding birds in Britain and Ireland. Tring: British Trust for Ornithology.

Sinclair, G. 1965. Land use map of Exmoor. Second Land Utilization Survey of Great Britain. London: Geography Department, King's College, University of London.

Sinclair, G. 1966. Can Exmoor survive? Bratton Fleming: Exmoor Society.

Sinclair, G. 1968. Withypool Common: present and future use. Exmoor Rev., 9, 54-61.

Sinclair, G. 1970. The vegetation of Exmoor. Dulverton: Exmoor Press.

Smith, A.N. \& Thomas, B. 1956. The nutritive value of Calluna vulgaris. IV. Digestibility at three, seven and fourteen years after burning. J. agric. Sci., Camb., 47, 468-475.

Soil Survey of England and Wales. 1974. Soil map of England and Wales. Har penden: Soll Survey.

Thomas, B. 1956. Heather (Calluna vulgaris) as a food for 1ivestock. Herb. Abs. , 26, 1-7.

Thomas, B. Fairbairn, C.B. 1957. A note on the digestibility of Nardus stricta. J. agric. Sci., Camb., 48, 413-414.

Thomas, B. \& Ibbotson, C.F. 1947. A note on the digestibility of Molinia caerulea. J. agric. Sci., Camb., 30, 58-59.

Thomas, B. Smith, A.N. 1954. The nutritive value of Calluna vulgaris. III. Digestibility at four and ten years after burning. J. agric. Sci., Camb., 45, 104-109.

Tubbs, C.R. \& Jones, E.L. 1964. The distribution of gorse (Ulex europaeus L.) in the New Forest in relation to former land use. Proc. Hampshire Field Club, 23, 1-10.

Watson, A. \& Miller, G.R. 1976. Grouse management. 2 nd ed. Fordingbridge: Game Conservancy.

Watson, A. \& O'Hare, P.J. 1979a. Bird and mammal numbers on untreated and experimentally treated Irish bog. 0ikos, 33, 97-105.

Watson, A. \& O'Hare, P.J. 1979b. Red grouse populations on experimentally treated and untreated Irish bog. J. appl. Ecol., 16, 433-452.

Watson, A., Moss, R., Phillips, J. \& Parr, R. 1977. The effect of fertilizers on red grouse stocks on Scottish moors grazed by sheep, cattle and deer. In: Ecologie du petit gibier, edited by $P$. Pesson and M.G. Birkan, 193-212. Paris: Gauthier-Villars.

Watt, A.S. 1955. Bracken versus heather, a study in plant sociology. J. Ecol., 43, 490-506.

Welch, D. 1968. Sheep grazing in northern England: some ecological consideration. In: H111-land productivity, edited by I.V. Hunt, 173-176. (Occasional symposium no. 4). Hurley: British Grassland Society.

Whitehead, G.K. 1964. The deer of Great Britain and Ireland. London: Routledge \& Kegan Paul.

Whittaker, E. 1961. Temperatures in heath fires. J. Ecol., 49, 168-178. 
Appendix 1. Relative proportions of different vegetation types (expressed as percentage to the nearest $1 \%$ ) in the 5 Exmoor regions. Data from Sinclair (1970) and Appendix 2. The number in parenthesis after each vegetation type shows the category into which the type was merged in Table 2.4

$\begin{array}{llll} & \text { Northern Central } & \text { Southern } \\ \text { Coastal heather } & \text { grass } & \text { heather } \\ \text { heaths moondon } & \text { moors } & \text { moors } & \text { meaths }\end{array}$

\begin{tabular}{|c|c|c|c|c|c|}
\hline Heather alone (1) & 14 & 40 & 0 & 18 & 0 \\
\hline Heather dominant (1) & 26 & 31 & $<1$ & 27 & 51 \\
\hline Bracken dominant (4) & 27 & 14 & 3 & 29 & 28 \\
\hline Bracken with heather (4) & 2 & 3 & $<1$ & 5 & 13 \\
\hline Fescue heaths* (2) & 20 & 7 & 2 & 9 & 3 \\
\hline Gorse dominant (5) & $12 * *$ & $<1$ & 0 & $<1$ & 5 \\
\hline Deer-grass dominant (6) & 0 & 0 & 1 & 0 & 0 \\
\hline Purple moor-grass alone (3) & 0 & $<1$ & 27 & 0 & 0 \\
\hline Purple moor-grass dominant (3) & 0 & 2 & 40 & 2 & 0 \\
\hline Fescue moors**t (2) & 0 & 2 & 13 & 9 & 0 \\
\hline $\begin{array}{l}\text { Fescue with purple } \\
\text { moor-grass ( } 2 \text { ) }\end{array}$ & 0 & $<1$ & 4 & 1 & 0 \\
\hline Area mapped (ha) & 670 & 7080 & 4940 & 5040 & 760 \\
\hline
\end{tabular}

* Fescue/bent with heather, bracken and gorse on dry sites

* Probably mostly dwarf furze, not gorse

*** Fescue/bent with mat-grass, cotton grass and rushes on wet sites 
Appendix 2. Relative proportions of different vegetation types (expressed as percentage to the nearest $1 \%$ ) in the 4 Exmoor regions. Data calculated from maps in Davies and Jarman (1978). Vegetation types are numbered to show the categories into which they were merged in Table 2.4

Northern Central
Coastal heather grass heather
heaths moors moors moors

1. Heather
a. alone
b. with subdominant bent/ fescue grassland species
c. with subdominant purple moor-grass
d. with subdominant bracken
e. with subdominant gorse

0

25

0

19

$\begin{array}{rr}6 & 23 \\ 0 & 0 \\ 0 & 26 \\ 13 & 4\end{array}$

\section{4}

2. Bent/fescue
a. alone
b. with subdominant heather
c. with subdominant purple moor-grass
d. with subdominant bracken

2

3. Purple moor-grass
a. alone
0

2

$\begin{array}{rr}20 & 4 \\ 60 & 0 \\ 2 & 8\end{array}$

4. Bracken
a. alone
b. with subdominant heather
c. with subdominant bent/ fescue grassland species
d. with subdominant purple moor-grass
e. with subdominant gorse

$\begin{array}{rrrr}17 & 4 & 3 & 10 \\ 0 & 0 & 0 & 2 \\ 15 & 0 & 0 & 8 \\ 0 & 0 & 0 & 3 \\ 0 & 0 & 0 & <1\end{array}$

5. Gorse
a. alone
b. with subdominant heather
c. with subdominant bent/ fescue grassland species
d. with subdominant purple moor-grass
e. with subdominant bracken

6. Bog

Area mapped (ha)

$\begin{array}{rrrr}1 & 0 & <1 & 2 \\ 0 & <1 & 2 & 2 \\ 0 & 0 & 0 & <1 \\ 0 & 0 & 0 & <1 \\ 4 * & 0 & 0 & 3 \\ 0 & <1 & 2 & 5 \\ 880 & 6330 & 4190 & 3800\end{array}$

* Probably mostly dwarf furze (Ulex gallii), not gorse (U. europaeus) 
Appendix 3. Relative proportions (expressed as percentages to the nearest 1\%) of . Evans et a1. (1977) vegetation types in the different regions of Exmoor (ie the proportion of quadrats of each type expressed as a percentage of the total number of quadrats described in that region in $R$ Williams' unpublished survey). The number in parenthesis after each vegetation type shows the catégory into which the type was merged in Table 2.4

\begin{tabular}{|c|c|c|c|c|c|c|c|}
\hline & Name & Brief description & $\begin{array}{l}\text { Coastal } \\
\text { heaths }\end{array}$ & $\begin{array}{l}\text { Northern } \\
\text { heather } \\
\text { moors }\end{array}$ & $\begin{array}{l}\text { Central } \\
\text { grass } \\
\text { moors. }\end{array}$ & $\begin{array}{l}\text { Southern } \\
\text { heather } \\
\text { moors }\end{array}$ & $\begin{array}{l}\text { Brendon } \\
\text { heaths }\end{array}$ \\
\hline 8. & $\begin{array}{l}\text { Juncetus effusi } \\
(2)\end{array}$ & $\begin{array}{l}\text { Rush (Juncus effusus)- } \\
\text { dominated marshy } \\
\text { grassland }\end{array}$ & 0 & $<1$ & $<1$ & $<1$ & 0 \\
\hline 9 . & $\begin{array}{l}\text { Sphagneto- } \\
\text { Caricetum sub- } \\
\text { alpine ( } 6)\end{array}$ & A type of bog on peat & 0 & 0 & $<1$ & $<1$ & 0 \\
\hline 10. & $\begin{array}{l}\text { Molinietum- } \\
\text { atlanticum (3) }\end{array}$ & $\begin{array}{l}\text { A bog on peat dominated } \\
\text { by purple moor-grass }\end{array}$ & 0 & 2 & 14 & 2 & 0 \\
\hline 11. & $\begin{array}{l}\text { Trlchophoreto- } \\
\text { Callunetum (6) }\end{array}$ & $\begin{array}{l}\text { A type of bog on peat } \\
\text { with abundant deer- } \\
\text { grass and purple moor- } \\
\text { grass }\end{array}$ & 0 & $\begin{array}{l}<1 \\
\therefore ;\end{array}$ & 3 & $<1$ & : \\
\hline 12 . & $\begin{array}{l}\text { Molinieto- } \\
\text { Callunetum (3) } \\
\text { : }\end{array}$ & $\begin{array}{l}\text { Purple moor-grass rich } \\
\text { dwarf shrub heath, } \\
\text { usually on thin peat }\end{array}$ & 4 & 18 & 17 & 20 & 24 \\
\hline 13. & $\begin{array}{l}\text { Calluneto- } \\
\text { Eriophoretum } \\
\text { typicum (6) }\end{array}$ & $\begin{array}{l}\text { Cotton-grass bog on } \\
\text { peat with abundant } \\
\text { heather }\end{array}$ & 0 & $<1$ & $<1$ & $<1$ & 0 \\
\hline 14 . & $\begin{array}{l}\text { Calluneto- } \\
\text { Erlophoretum } \\
\text { deschampsiosum ( } 6 \text { ) }\end{array}$ & $\begin{array}{l}\text { Cotton-grass bog on } \\
\text { peat with little } \\
\text { heather and abundant } \\
\text { wavy-hair grass }\end{array}$ & 0 & $<1$ & $<1$ & 0 & 0 \\
\hline 16. & $\begin{array}{l}\text { Nardo-Juncetum } \\
\text { squarrosi ( } 2)\end{array}$ & $\begin{array}{l}\text { Mat-grass and heath } \\
\text { rush-doml nated } \\
\text { grassland on wet soils }\end{array}$ & 0 & 2 & 8 & 2 & 3 \\
\hline 17. & $\begin{array}{l}\text { Agrosto- } \\
\text { Festucetum (2) }\end{array}$ & $\begin{array}{l}\text { Bent/fescue grassland } \\
\text { on actd soils }\end{array}$ & 5 & 2 & 6 & 5 & 0 \\
\hline 18. & $\begin{array}{l}\text { Trifolio-Agrosto- } \\
\text { Festucetum ( } 2)\end{array}$ & $\begin{array}{l}\text { Bent/fescue grassland } \\
\text { with white clover on } \\
\text { relatively base-rich } \\
\text { soils }\end{array}$ & 0 & 0 & $<1$ & $<1$ & 0 \\
\hline 19. & $\begin{array}{l}\text { Festuco-Molinietum } \\
\text { deschampsiosum ( } 3 \text { ) }\end{array}$ & $\begin{array}{l}\text { Purple moor-grass } \\
\text { dominated bent/fescue }\end{array}$ & 2 & 4 & 29 & 7 & 3 \\
\hline 20. & $\begin{array}{l}\text { Fes tuco-Molinietum } \\
\text { anthoxanthosum (3) }\end{array}$ & $\begin{array}{l}\text { Purple moor-grass } \\
\text { dominated bent/fescue } \\
\text { grassland on relatively } \\
\text { base-rich soils }\end{array}$ & 0 & 2 & 4 & 3 & 0 \\
\hline
\end{tabular}


Appendix 3 (continued)

\begin{tabular}{|c|c|c|c|c|c|c|c|}
\hline$\therefore$ & Name $\quad \cdots \quad$ & Brief description & $\begin{array}{l}\text { Coastal } \\
\text { heaths }\end{array}$ & $\begin{array}{l}\text { heather } \\
\text { moors }\end{array}$ & $\begin{array}{l}\text { grass } \\
\text { moors }\end{array}$ & $\begin{array}{l}\text { heather } \\
\text { moors }\end{array}$ & $\begin{array}{l}\text { Brendon } \\
\text { heaths }\end{array}$ \\
\hline & $\therefore \ldots=$ & $\therefore$ & & $\because$ & $\because$ & & \\
\hline 21. & $\begin{array}{l}\text { Peridietum } \\
\text { aquilinae }(4)\end{array}$ & $\begin{array}{l}\text { Bracken-dominated bent/ } \\
\text { fescue grassland }\end{array}$ & 17 & 6. & 4 & 12 & 21 \\
\hline 22. & $\begin{array}{l}\text { Callunetum vulgaris } \\
\text { typicum (1) }\end{array}$ & $\begin{array}{l}\text { Heather-dominated } \\
\text { dwarf shrub heath }\end{array}$ & 3 & 13 & 1 & 9 & 9 \\
\hline 23. & $\begin{array}{l}\text { Cailunetum vulgaris } \\
\text { cinerea (1) }\end{array}$ & $\begin{array}{l}\text { Heather-dominated } \\
\text { dwarf shrub heath with } \\
\text { abundant bell heather }\end{array}$ & 52 & $\begin{array}{l}7 \\
\vdots \\
\cdots\end{array}$ & 0 & 5 & 3 \\
\hline 24. & $\begin{array}{l}\text { Festuceto- } \\
\text { Vaccinietum } \\
\text { pteridosum (2) }\end{array}$ & $\begin{array}{l}\text { Bllberry-rich bent/ } \\
\text { fescue grassland, with } \\
\text { frequent to abundant } \\
\text { bracken }\end{array}$ & 8 & 6 & 1 & : & 9 \\
\hline 25 . & $\begin{array}{l}\text { Festuceto- } \\
\text { Vaccinietum } \\
\text { nardosum (2) }\end{array}$ & $\begin{array}{l}\text { Bilberry-rich bent/ } \\
\text { fescue grassland with } \\
\text { frequent to abundant } \\
\text { mat-grass }\end{array}$ & $\begin{array}{l}<1 \\
\ddots\end{array}$ & 2 & 4 & 4. & 0 \\
\hline 26. & $\begin{array}{l}\text { Vaccinieto- } \\
\text { Callunetum } \\
\text { typicun (1) }\end{array}$ & $\begin{array}{l}\text { A grassy dwarf shrub } \\
\text { heath with heather and } \\
\text { bilberry variously domin } \\
\text { or co-dominant }\end{array}$ & 9 & 34 & 6 & 27 & 27 \\
\hline & (Number of quadrats & in each region) & $(237)$ & (917) & $(547)$ & (631) & (33) \\
\hline & Areas covered (ha) & & 1310 & 5370 & 3500 & 3810 & 200 \\
\hline
\end{tabular}


Appendix 4. Relative proportions of different vegetation types (expressed as percentages to the nearest $1 \%$ ) in the 5 Exmoor regions. Values calculated from the data from $R$ Hilliams' unpublished survey, vegetation types* following ITE (1978). The number in parentheses after each vegetation type shows the category into which the type was merged in Table 2.4

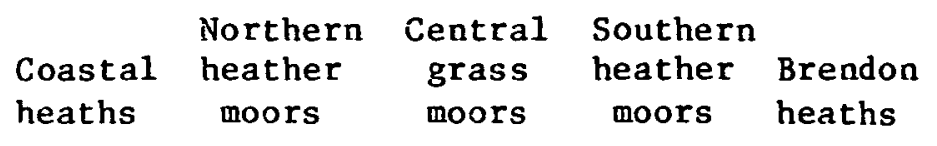

1. Dwarf shrubs** dominant without 20

12

$$
1
$$

8 9 significant cover by other species (1)

2. Dwarf shrubs** dominant with $5-20 \%$ cover by bent/ fescue grassland species (1)

3. Dwarf shrubs*t dominant with $>20 \%$ cover by bent/fescue grassland species (1)

4. Dwarf shrubs** dominant with $5-20 \%$ cover by purple moor-grass (1)

5. Dwarf shrub dominant with $>20 \%$ cover by purple moor-grass (1)

6. Dwarf shrubs dominant with $>20 \%$ cover by bracken (1)

7. Bent/fescue grassland without significant cover by other important species (2)

8. Bent/fescue grassland with $5-20 \%$ cover by dwarf shrubs** (2)

9. Bent/fescue grassland with $>20 \%$ cover by dwarf shrubs**

10. Purple moor-grass dominant without significant cover by other important species (3)

11. Purple moor-grass with $5-20 \%$ cover by dwarf shrubs** (3) $>20 \%$ cover by dwarf shrubs** (3)

13. Bracken dominant with dwarf shrubs** understorey (4) 


\section{Appendix 4 (continued)}

$\begin{array}{lll} & \text { Northern Central } & \text { Southern } \\ \text { Coastal heather grass heather Brendon } \\ \text { heaths moors moors moors heaths }\end{array}$

15. Gorse dominant with dwarf shrub** 0

1

0

4

3

understorey (5)

16. Gorse dominant with bent/fescue

1

0

1

3 grassland understorey (5)

17. Gorse dominant over predominantly bracken understorey (5)

18. Bog (characterized by a predominance of species such as deer-grass, cotton-grass or Sphagnum moss) (6)

19. Marsh (defined by species 0

1

0

1

characteristic of permanently wet

mineral soils) (6)

In defining the sub-dominant species, the presence of bent/fescue grassland species was given priority over the same cover of purple moor-grass, with the result that the incidence of dwarf shrub dominant vegetation with $5-20 \%$ purple moor-grass has been greatly underestimated

Heather was usually dominant, but dwarf furze was frequently dominant or co-dominant on the coastal heaths, and bilberry sometimes so elsewhere 
Appendix 5. Parishes were grouped according to the moorland region in which they were principally located, as follows:

A. Coastal !eaths.

\section{Conbe Martin \\ Countisbury \\ Martinhoe}

B. Northern heatner moors
Trent isoe

Selworthy

Minehead Without
Cutcombe

Luccombe

Dare

Porlock

Wooton Courtney

C. Central grass moors

Exmoor

D. Southern heather moors

$$
\begin{aligned}
& \text { High Bray } \\
& \text { Dulverton }
\end{aligned}
$$

Winsford

Withypool

E. Brendon heaths

\author{
Brompton Regis \\ Upton \\ Dunster
}

\author{
Luxborough \\ Timbers combe \\ Treborough
}


Appendix 6. This Appendix considers how a given width of a marginal zone of successionally changed vegetation (the 'edge effect') influences the area remaining of unchanged vegetation, expressed as a proportion of the total area. For regular geometrical shapes, precise mathematical formulae can be derived showing the relationship of total area, marginal zone width, and the remaining central area. Consider the case for a circle:

Let $R$ denote the radius of the circle, then, its area $=\pi R^{2}$, and its perimeter $=2 \pi R$.

The area:perimeter ratio $=R / 2,=Q$, say.

Moving in a distance $d$ from the perimeter (where $d<R$ ) gives an interior circle of radius $R-d$.

Therefore, the area remaining, $P_{r}=\pi(R-d)^{2}$, which is a proportion $[1-(d / R)]^{2}$ of the original, or $\left.[1-d / 2 Q)\right]^{2}$.

Thus, the proportion of area remaining can be expressed simply in terms of the width of the edge effect and the area:perimeter ratio. If the shape of any heather moorland block, for example, could be considered as approximating to a circle, the influence of different widths of edge effect on the remaining proportion of heather could be estimated, as both areas and perimeters are readily calculated from maps. This equation was tested for a series of artificial shapes of varying size and form. Estimated values of $P_{r}$ agreed surprisingly well with real values. Discrepancies were greatest when $d$ was large in relation to area, while estimated and real values of $P_{r}$ converged as the area increased. Further, the relationship still worked well when the shapes contained holes to represent patches converted to grassland within a moor. (In this case, the perimeter of the hole was added to the outside perimeter of the moor, and its area, of course, subtracted.)

Next, 8 actual blocks of heather moorland with distinct marginal zones of non-heathery vegetation were examined to see how well the relationship worked in practice. Table A shows the real and predicted proportions of heather-dominant vegetation. Considering that the moors were not true circles, there is a gratifying degree of correspondence between the 2 sets of values. As with the artificial shapes, so only when the moors were very small did the real and predicted values deviate substantially. (In this exercise, examining the smaller moors would also have involved greater percentage errors in estimating areas and perimeters.) This correspondence is shown graphically in Figure $A$, where the real and predicted values are superimposed on the plotted relationship for a circle between $P_{r}$ and $d / 2 Q$. Table $B$ gives the data from which the predictions in Table $A$ were made. It should be noted that, because of differences in shape and degree of undulation of perimeter, the area:perimeter ratios for these moors bear no relation to their areas. 


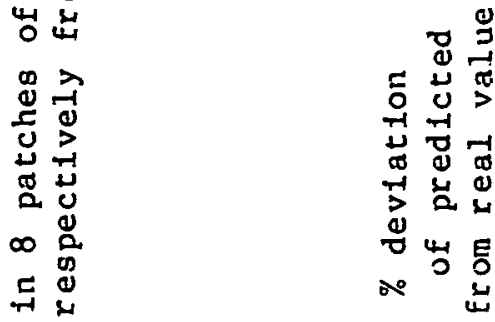

$$
0 \quad \vec{T} \vec{T} \quad \vec{i} \quad \vec{T} \quad \stackrel{T}{T}
$$

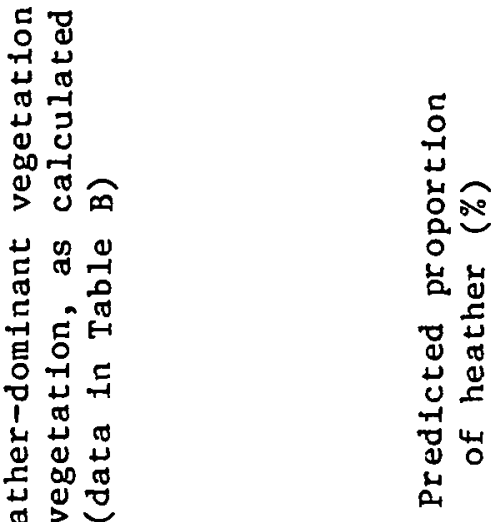

\&

㟧离

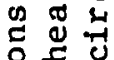

至点

品。

넝 웅

م.

导导苟

ఫ્ટુ

点

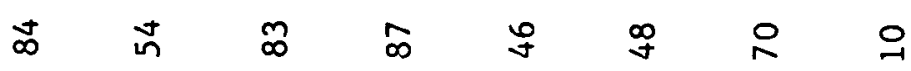

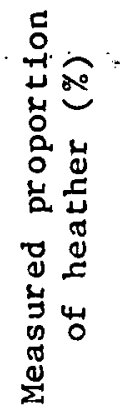

๖ా

苋 㟧

吾艺

ข

选 茴

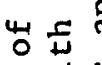

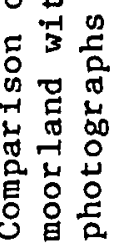

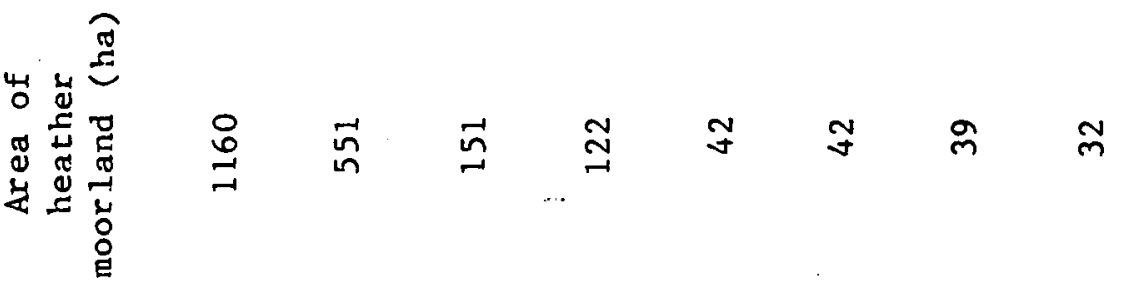

$\alpha$
0
0
0

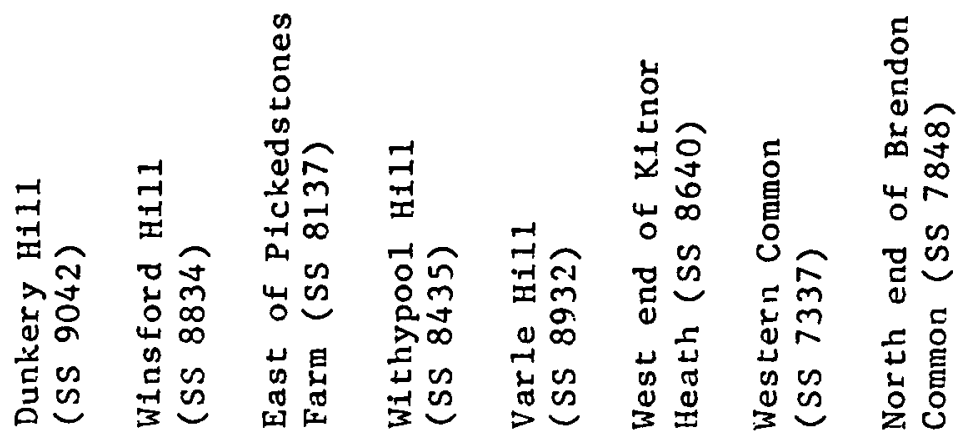


Figure A. The relationship for a circle of the proportion of internal area remalning, $P_{r}$, when the perimeter is moved in a distance $d$, as a function of the area:perimeter ratio, $Q$, with the real

(o) and predicted (.) values of $P_{r}$ for 8 moors superimposed

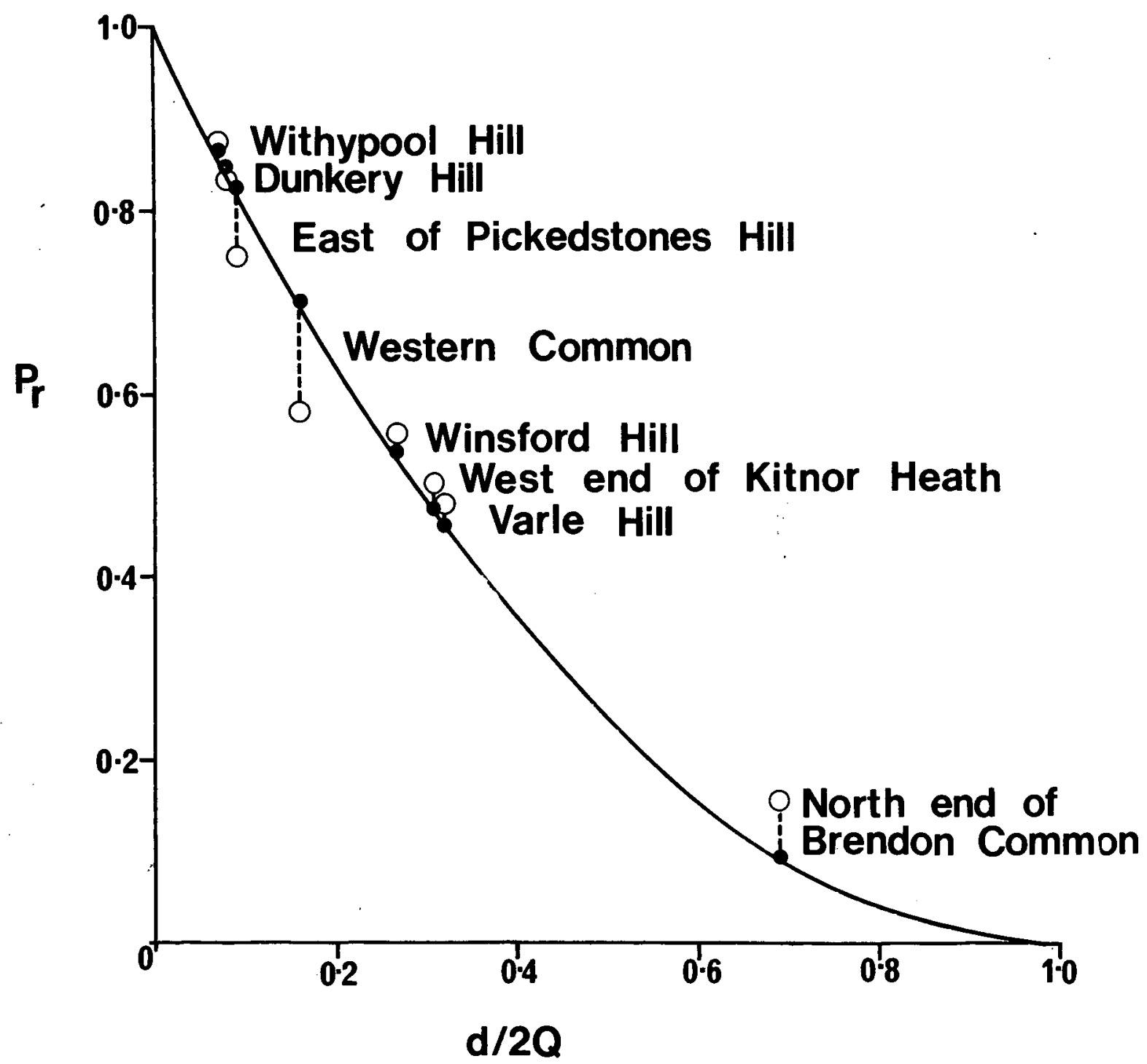


马ु

过苛*

फै

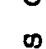

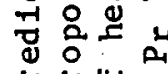

$\$$

in $\infty \begin{array}{llllll}\infty & \infty & + & \stackrel{\infty}{+} & & \end{array}$

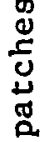

焉

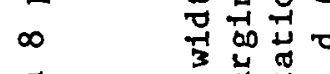

두

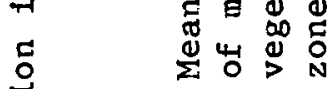

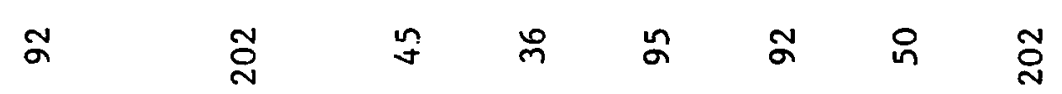

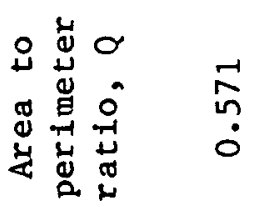

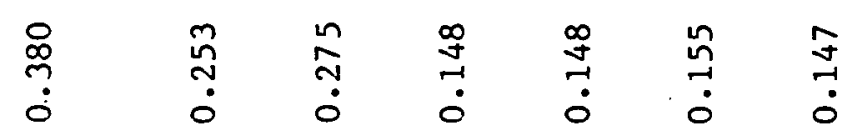

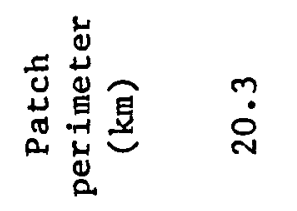

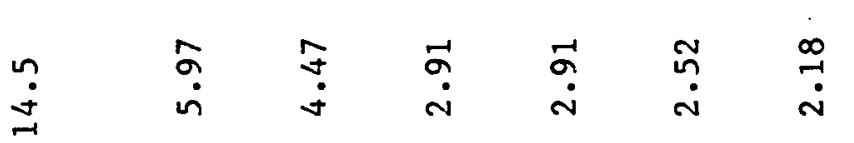

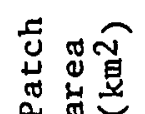

$\stackrel{0}{\leftrightarrows}$

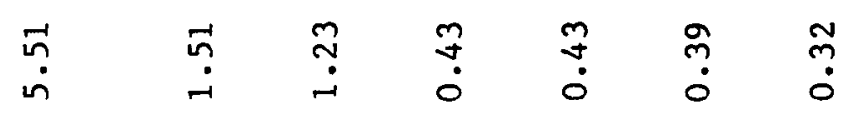

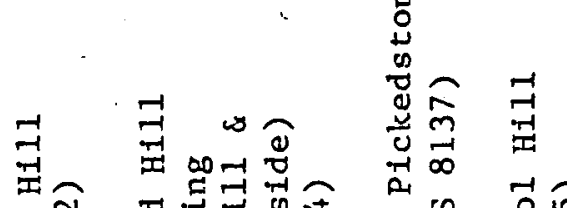

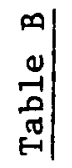

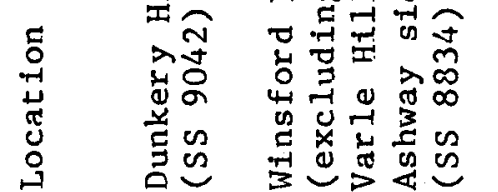

क⿻

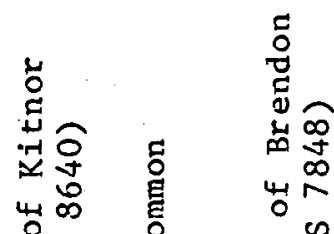

㟧

芠

4

:

:

至

on

势落

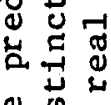

ป⿻

岁秘

53

牙营

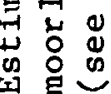

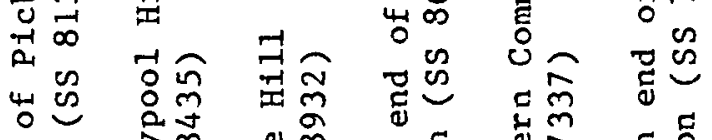

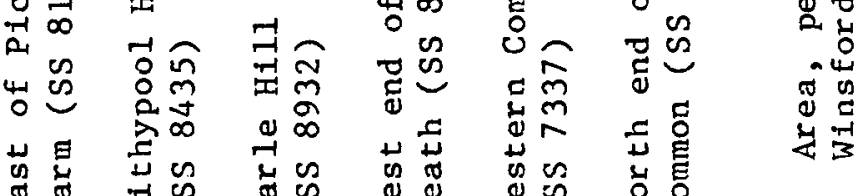


Appendix 7. Aerial photographs of. Exmoor National Park are held at the Air Photographs Unit, Department of the Environment, Prince Consort Road, Albert Embankment, London SEl 7TF. The following are available (all are at scale 1:10 000, unless stated otherwise)

Sortie number

106G/UK/1420

3G/TUD/UK/207

106G/UK/1655

3G/TUD/UK/221

CPE/UK/1944

CPE/UK/1974

CPE/UK/1980

CPE/UK/2082

58/RAF/2665

58/RAF/5154

58/RAF/5159

58/RAF/2332

58/RAF/7109

58/RAF/9371

543/RAF/4647
April 46

May 46

July 46

July 46

January 47

April 47

April 47

May 47

January 59

June 62

June 62

Ju1y 63

November 65

$1: 22000$

February 69

$1: 32000$

March 69

of these, sortie number CPE/UK/1980, flown in April 1947, gives almost complete coverage of the Park. In addition, Meridian Airways photographed the entire area of the Park in June 1976. Copies of these photographs are held at Exmoor National Park Department, Exmoor House, Dulverton, Solnerset TA22" 9HL 
Appendix 8. Common and Latin names of fauna and flora mentioned in this report

\section{FAUNA}

\section{Insects}

Eulophid chalcid

Grey mountain carpet moth

Heather beetle

Amphibia

Frog, common

Toad, Common

Reptiles

Adder

Grass snake

Slow-worm

Viviparous lizard

Birds

Blackbird

Buzzard, common honey

Crow, carrion

rough-legged

Cuckoo

Cur lew

Dipper

Eagle, golden

white-tailed

Goshawk

Grouse, black

red

willow

Harrier, hen

marsh

Her on

Montague's

Hobby

Kestrel

Kite, red

Lapwing

Linnet

Mer lin

Night jar

Ouzel, ring

Owl, short-eared

Peregrine

Pipit, meadow

tree

Plover, golden

Ptarmigan
Asecodes mento Entephria caesiata Lochmaea suturalis

Rana temporaria temporaria Bufo bufo bufo

Vipera berus berus

Natrix natrix

Anguis fragilis

Lacerta vivipara

Turdus merula

Buteo buteo

Pernis apivorus

Buteo lagopus

Corvus corone

Cuculus canorus

Numenius arquata

Cinclus cinclus

Aquila chrysaetos

haliaeetus albicilla

Accipiter gentilis

Lyurus tetrix

Lagopus 1. scoticus

Lagopus 1. lagopus

Circus cyaneus

Circus aeruginosus

Circus pygargus

Ardea cinerea

Falco subbuteo

Falco tinnunculus

Milvus milvus

Vanellus vanellus

Acanthis cannabina

Falco columbarius

Caprimulgus europaeus

Turdus torquatus

Asio flammeus

Falco peregrinus

Anthus pratensis

Anthus trivialis

Charadrius apricarius

Lagopus mutus 


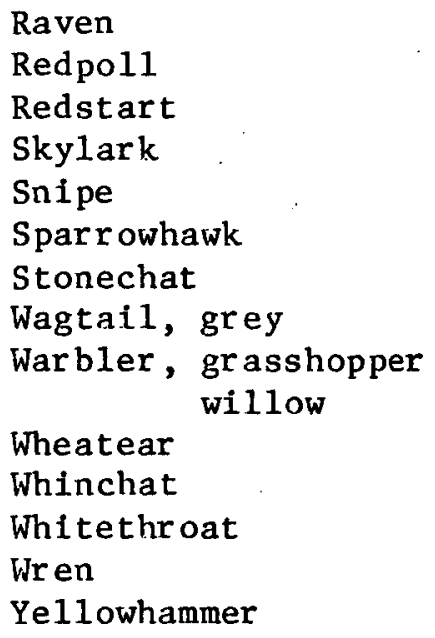

\section{FLORA}

Plants

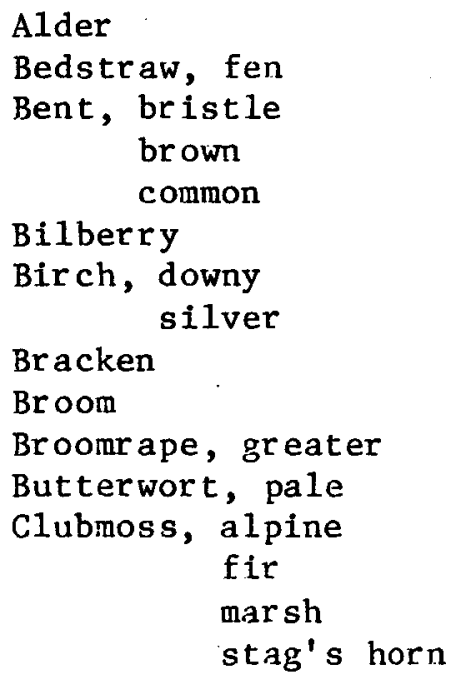

Corvus cor ax

Acanthis flammea

Phoenicurus phoenicurus

Alauda arvensis

Gallinago gallinago

Accipiter nisus

Saxicola torquata

Motacilla cinerea

Locustella naevia

Phylloscopus trochilus

Oenanthe oenanthe

Saxicola rubetra

Sylvia communis Troglodytes troglodytes Emberiza citrinella

Dama dama

Cervus elaphus

Capreolus capreolus

Cervus nippon

Vulpes vulpes

Lepus capensis

Mustela vison

Apodemus sylvaticus

Lutra lutra

Mustela putorius

Oryctolagus cuniculus Mustela erminea

Clethrionomys glareolus Microtus agrestis Mustela nivalis

Alnus glutinosa

Galium uliginosum

Agrostis setacea

Agrostis canina

Agrostis tenuis

Vaccinium myrtillus

Betula pubescens

Betula pendula

Pteridium aquilinum

Sarothamnus scoparius

Orobanche rapum-genistae

Pinguicula lusitanica

Lycopodium alpinum

Lycopodium selago

Lycopodium inundatum

Lycopodium clavatum 


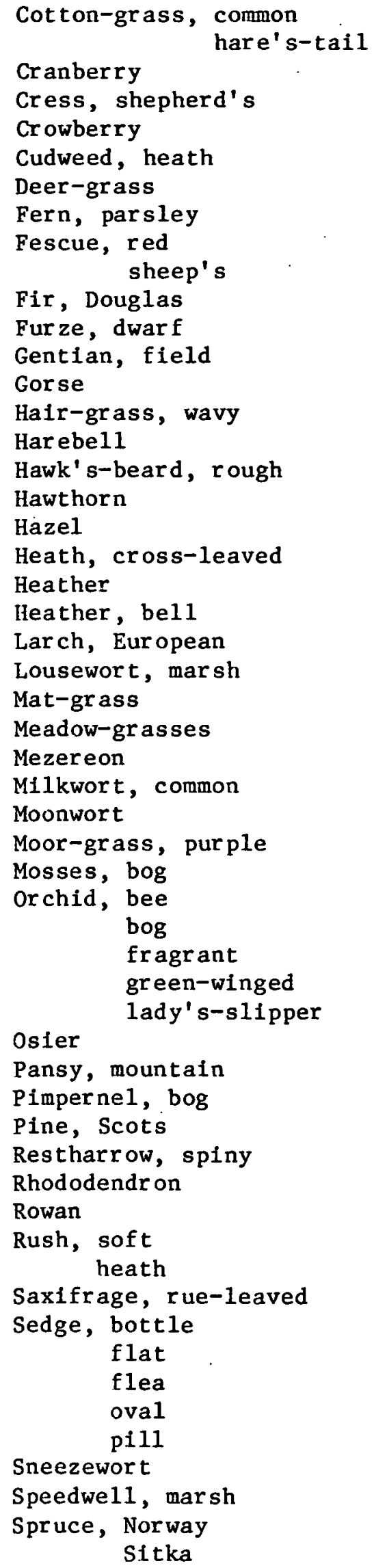

\author{
Eriophorum angustifolium \\ Eriophor um vaginatum \\ Vaccinium oxycoccus \\ Teesdalia nudicaulis \\ Empetrum nigrum \\ Gnaphalium sylvaticum \\ Trichophorum cespitosum \\ Cryptogramma crispa \\ Festuca rubra \\ Festuca ovina \\ Pseudotsuga menziesii \\ Ulex gallii \\ Gentianella campestris \\ Ulex europaeus \\ Deschampsia flexuosa \\ Campanula rotundifolia \\ Crepis biennis \\ Crataegus monogyna \\ Corylus avellana \\ Erica tetralix \\ Calluna vulgaris \\ Erica cinerea \\ Larix decidua \\ Pedicularis palustris \\ Nardus stricta \\ Poa spp. \\ Daphne mezereum \\ Polygala vulgar is \\ Botrychium lunaria \\ Molinia caerulea \\ Sphagnum spp. \\ Ophrys apifera \\ Hammar bya paludosa \\ Gymnadenia conopsea \\ Orchis morio \\ Cypripedium calceolus \\ Salix viminalis \\ Viola lutea \\ Anagallis tene 1la \\ Pinus sylvestris \\ Ononis spinosa \\ Rhododendron ponticum \\ Sorbus aucuparia \\ Juncus effusus \\ Juncus squarrosus \\ Saxifraga tridactylites \\ Carex rostrata \\ Blysmus compressus \\ Carex pulicaris \\ Carex ovalis \\ Carex pilulifera \\ Achillea ptarmica \\ Veronica scutellata \\ Picea abies \\ Picea sitchenis
}


Append1x 8 (continued)

St John's-wort, trailing

Hypericum humifusum

Sundews

Tare, slender

Tormentil, trailing

Twayblade, lesser

Vernal-grass, sweet

Vetch, bitter

violet, hairy

Whin, petty

Willow, creeping

Drosera spp.

Vicia tenuissima

Potentilla anglica

Listera cordata

Anthoxanthum odor atum

Lathyrus montanus

Viola hirta

Genista anglica

Salix repens

purple

Salix purpurea 


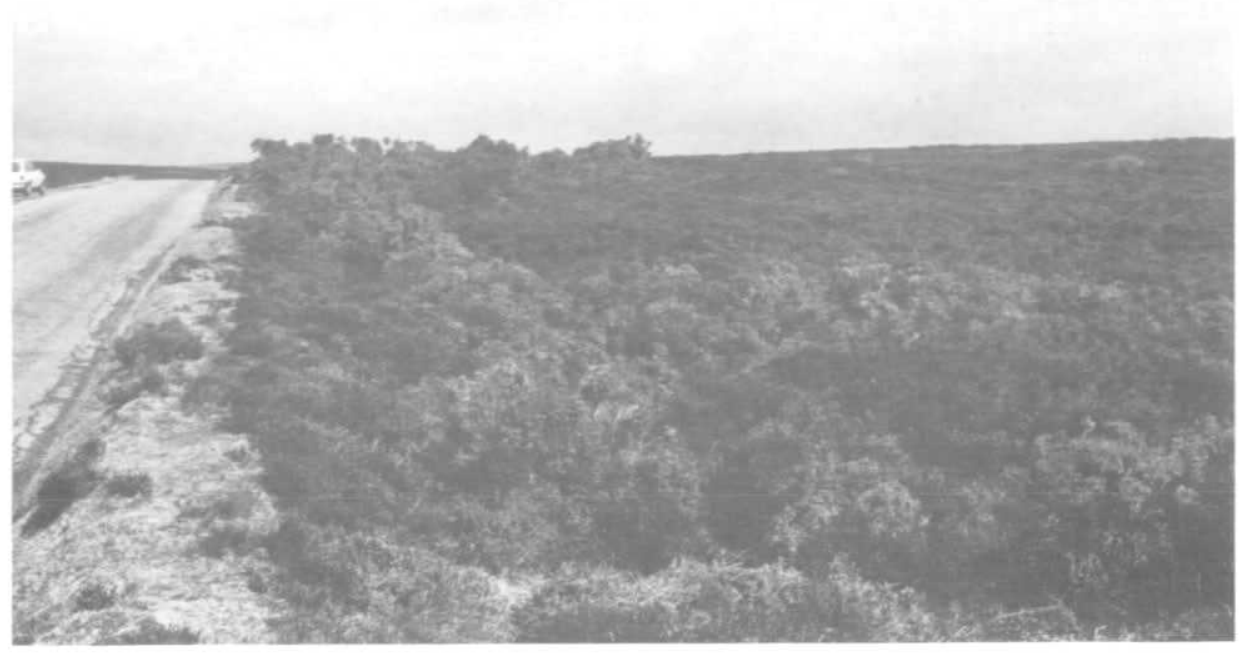

Plate 1. Heather moor with gorse along road verge at Winsford Hill

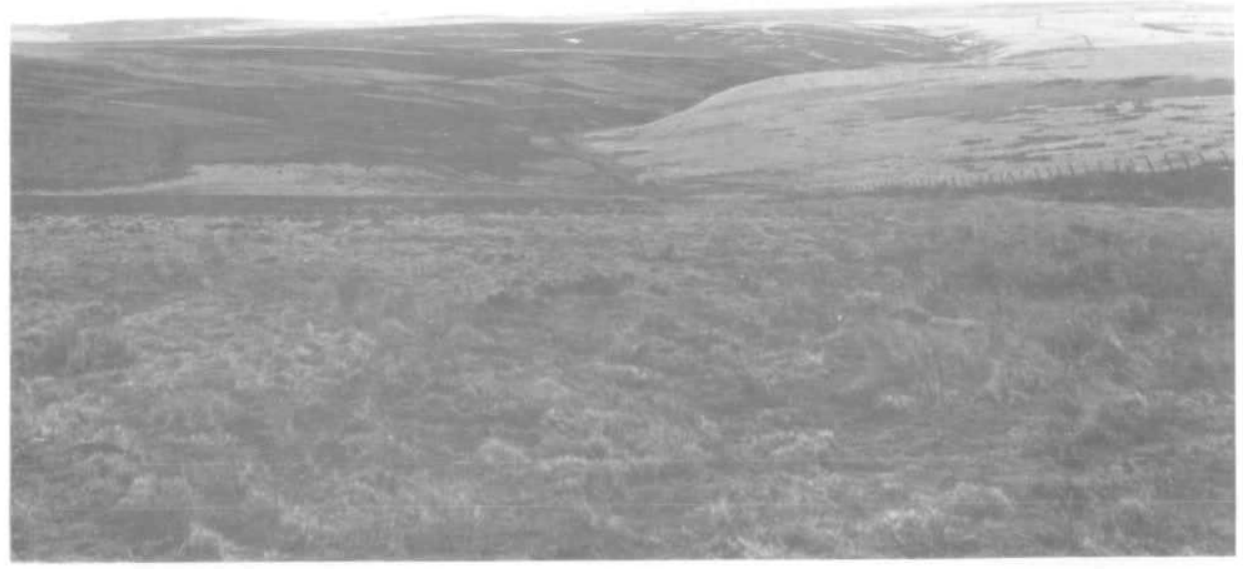

Plate 2. Boundary between heather moor and grass moor at Brendon Two Gates 



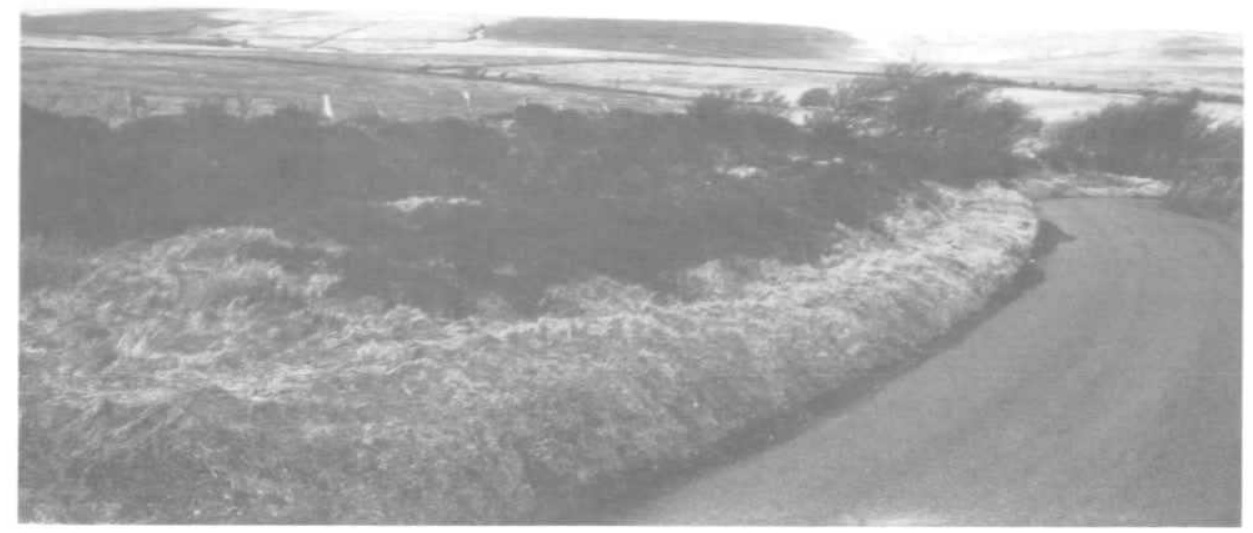

Plate 3. Heather on ungrazed road verge within grass moor at Kingsford Gate

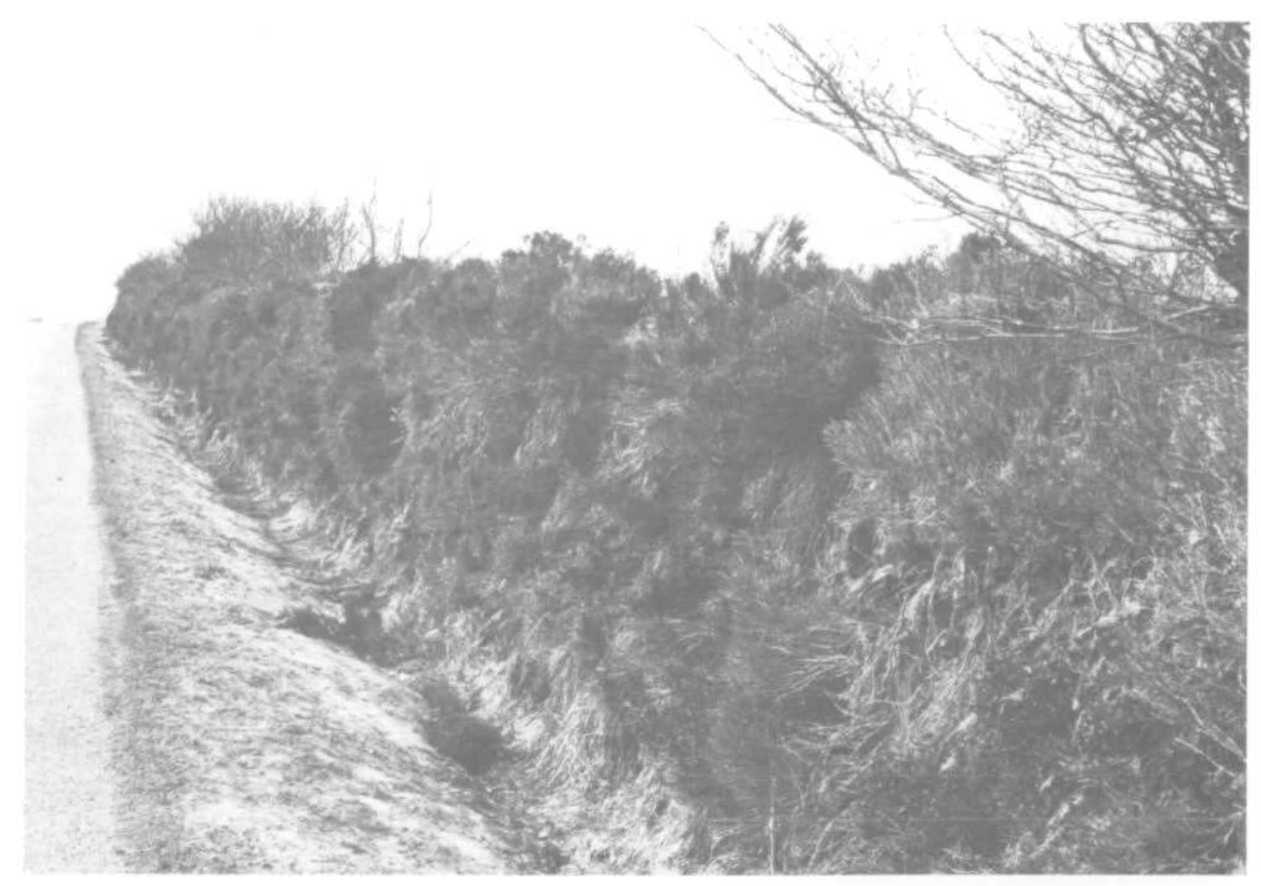

Plate 4. Heather and bilberry predominant on hedge bank within grass moor at Hangley cleave 



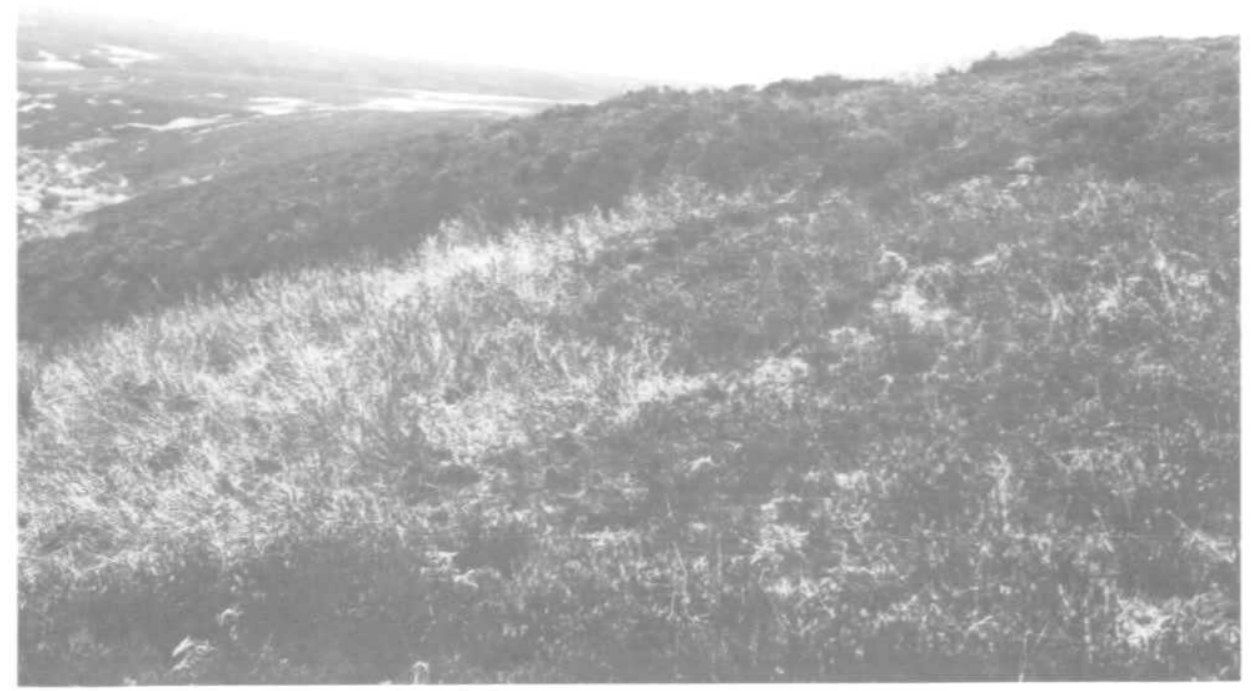

Plate 5. Poor and good regeneration 3 years after burning heather aged 23 years (left) and 7 years (right) at Wilmersham Common

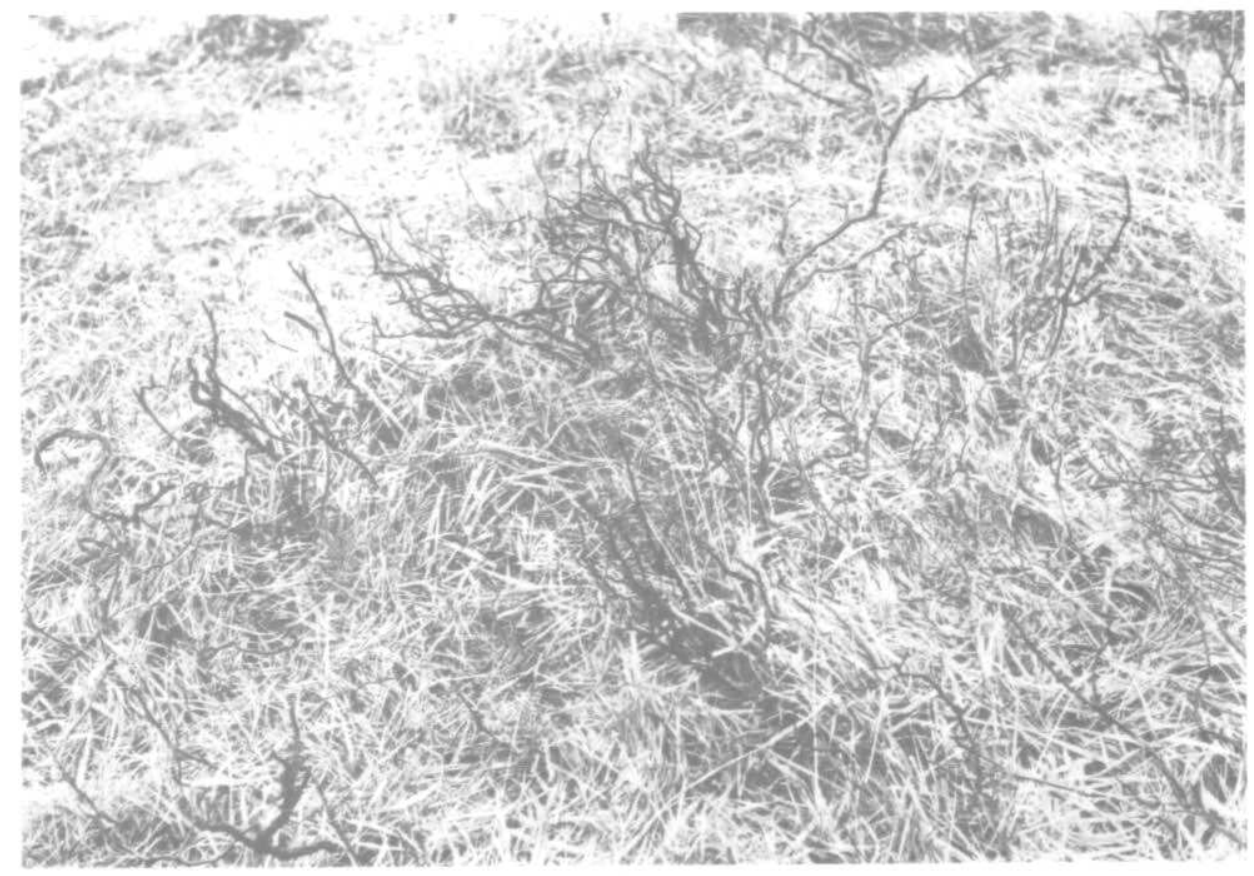

Plate 6. Purple moor-grass replacing 19 year old heather killed by fire at Withypool Common 



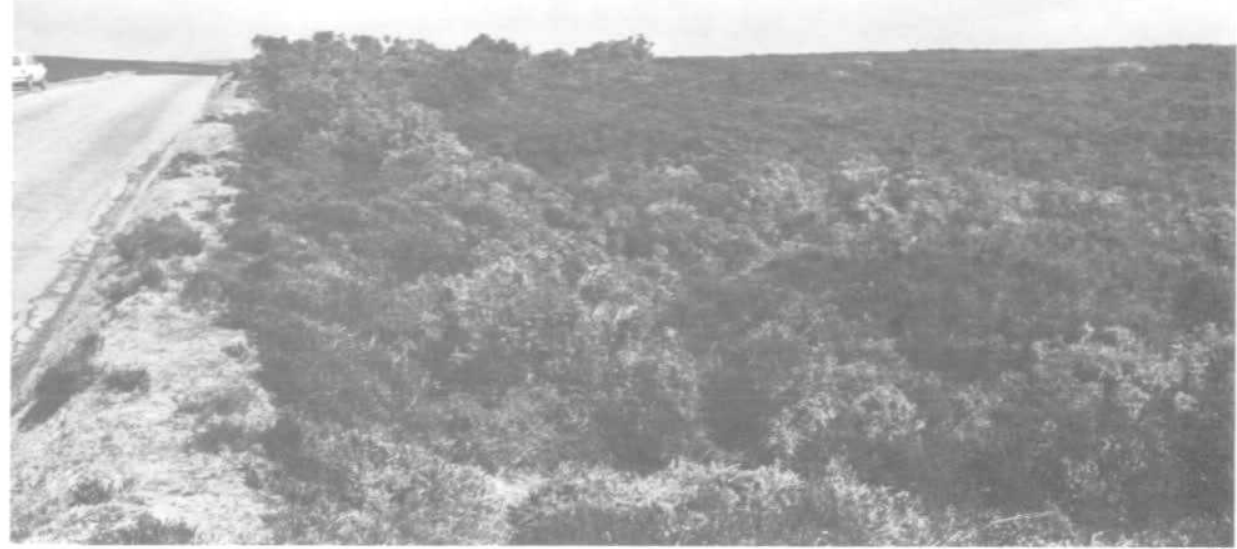

Plate 7. Bracken invading heather moor at Winsford Hill

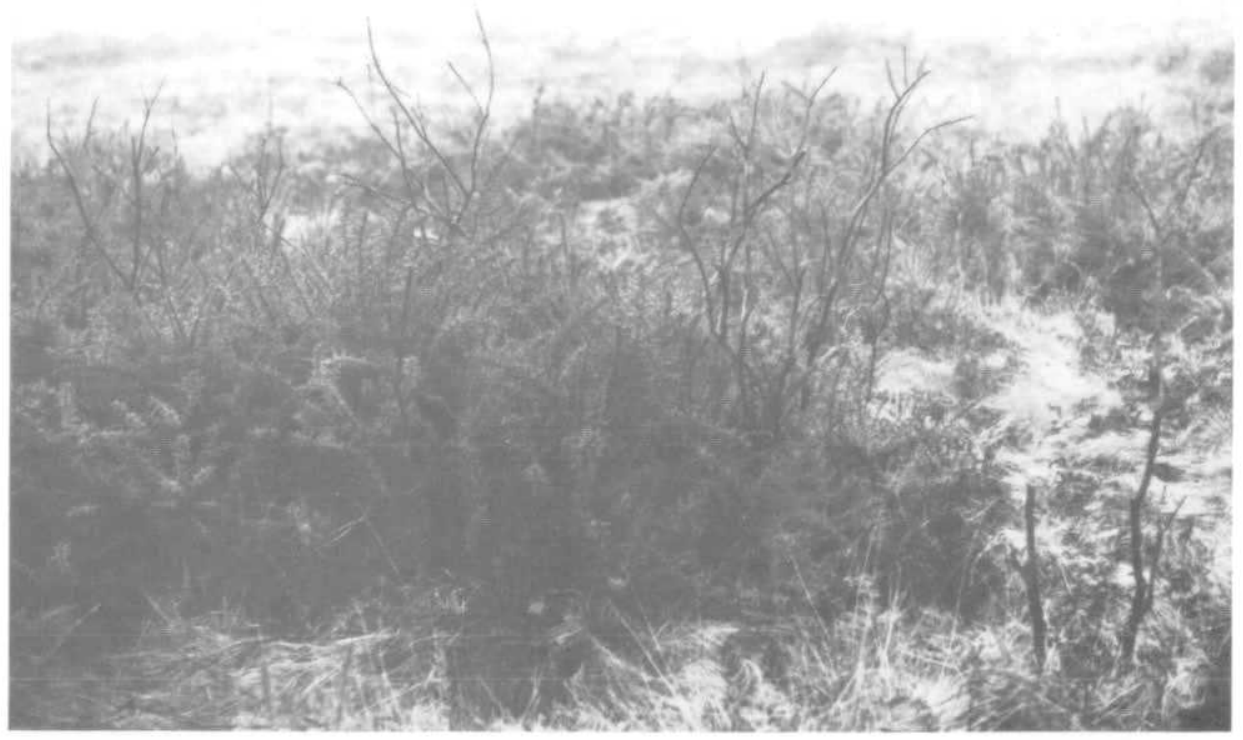

Plate 8. Vigorous regeneration of gorse 2 years after burning at East Anstey Common 



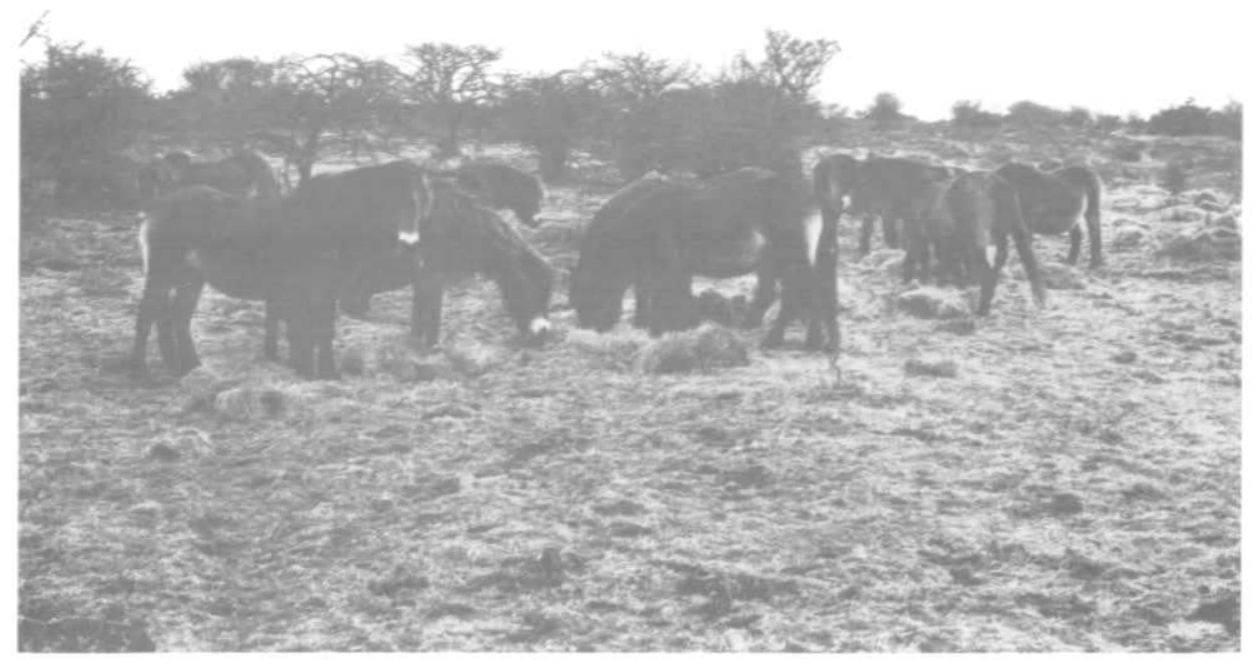

Plate 9. Winter feeding of livestock kills heather and poaches the ground at Winsford Hill

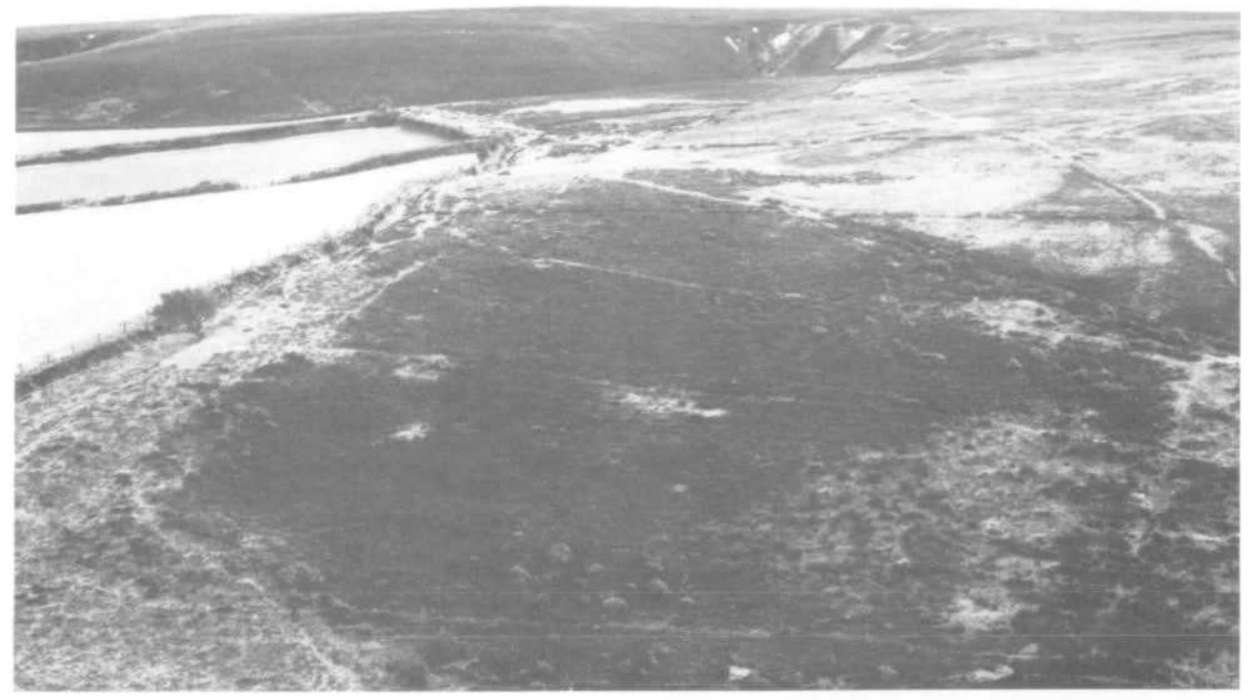

Plate 10. 'Edge effect' at north Brendon Common 


\section{.}




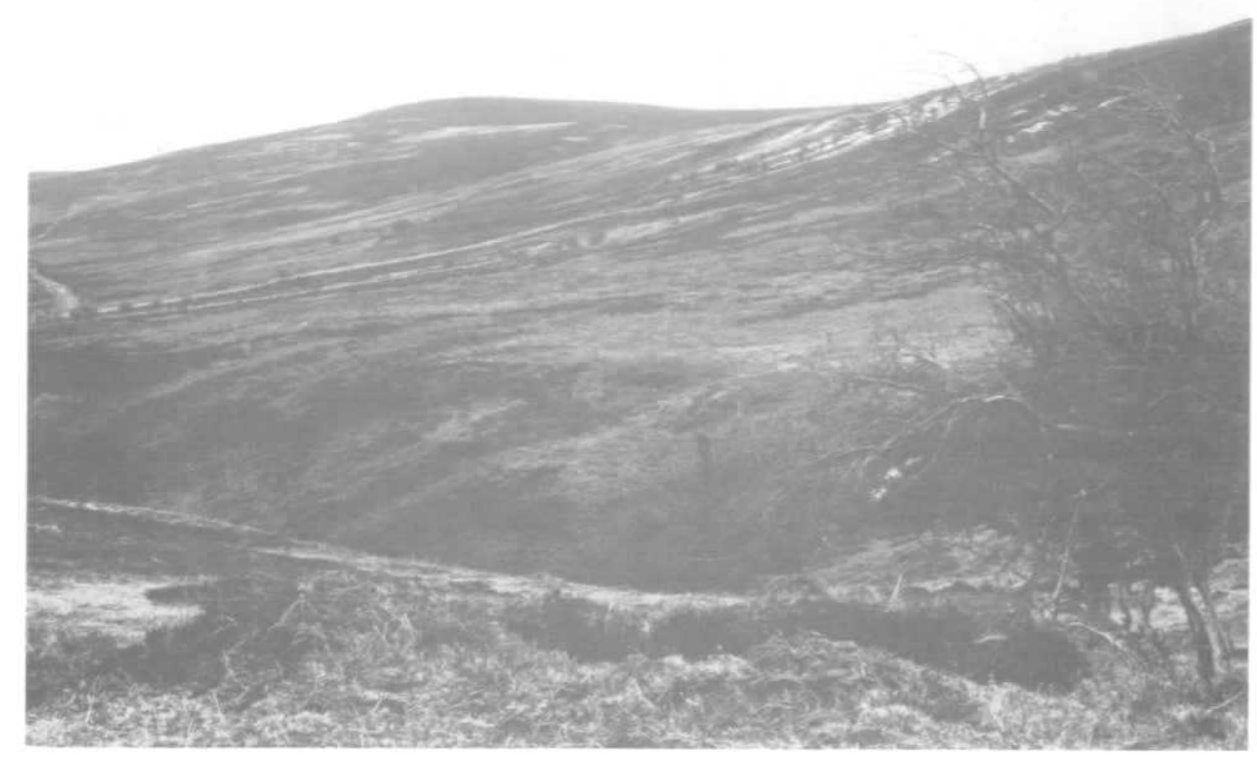

Plate 11. Bracken and grasses replacing heather at Stoke Pero Common

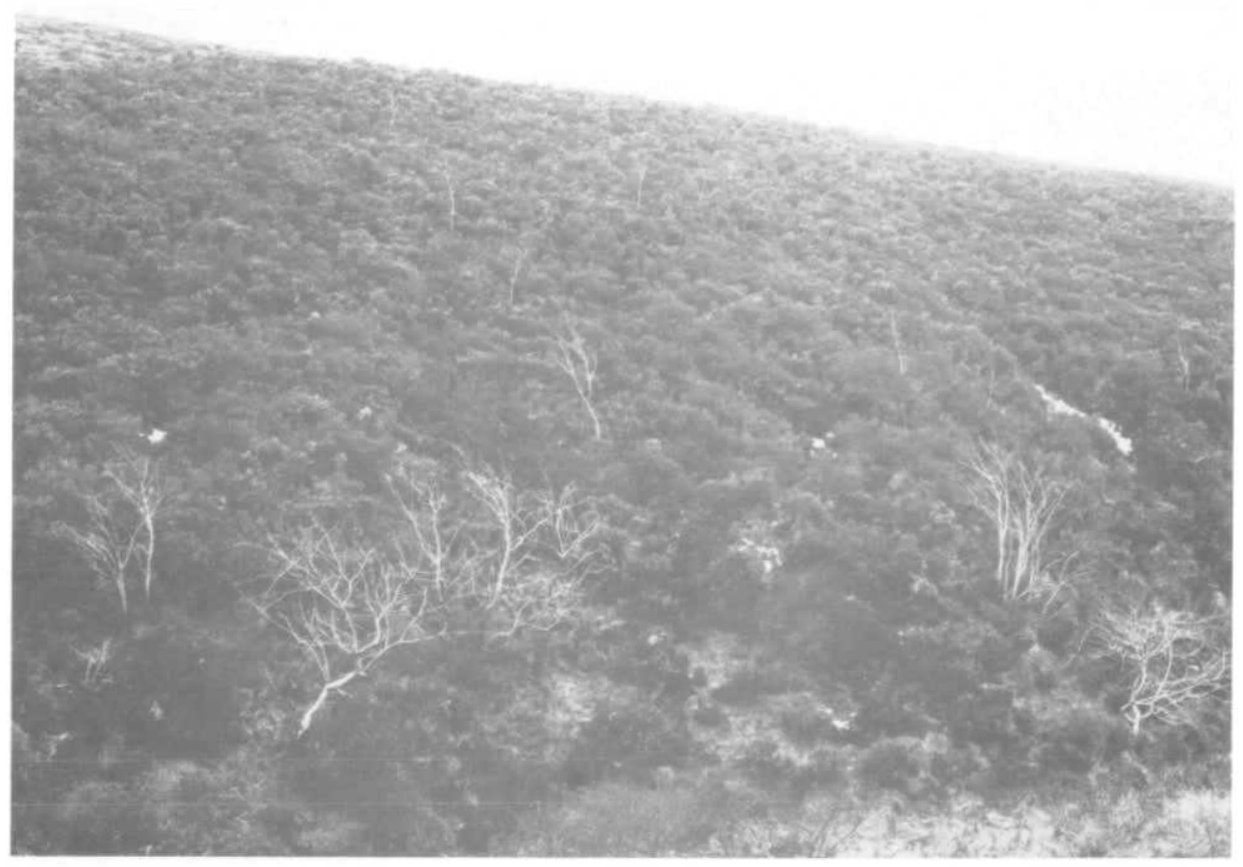

Plate 12. Rowan colonizing stand of degenerate heather at Wilmersham Common 




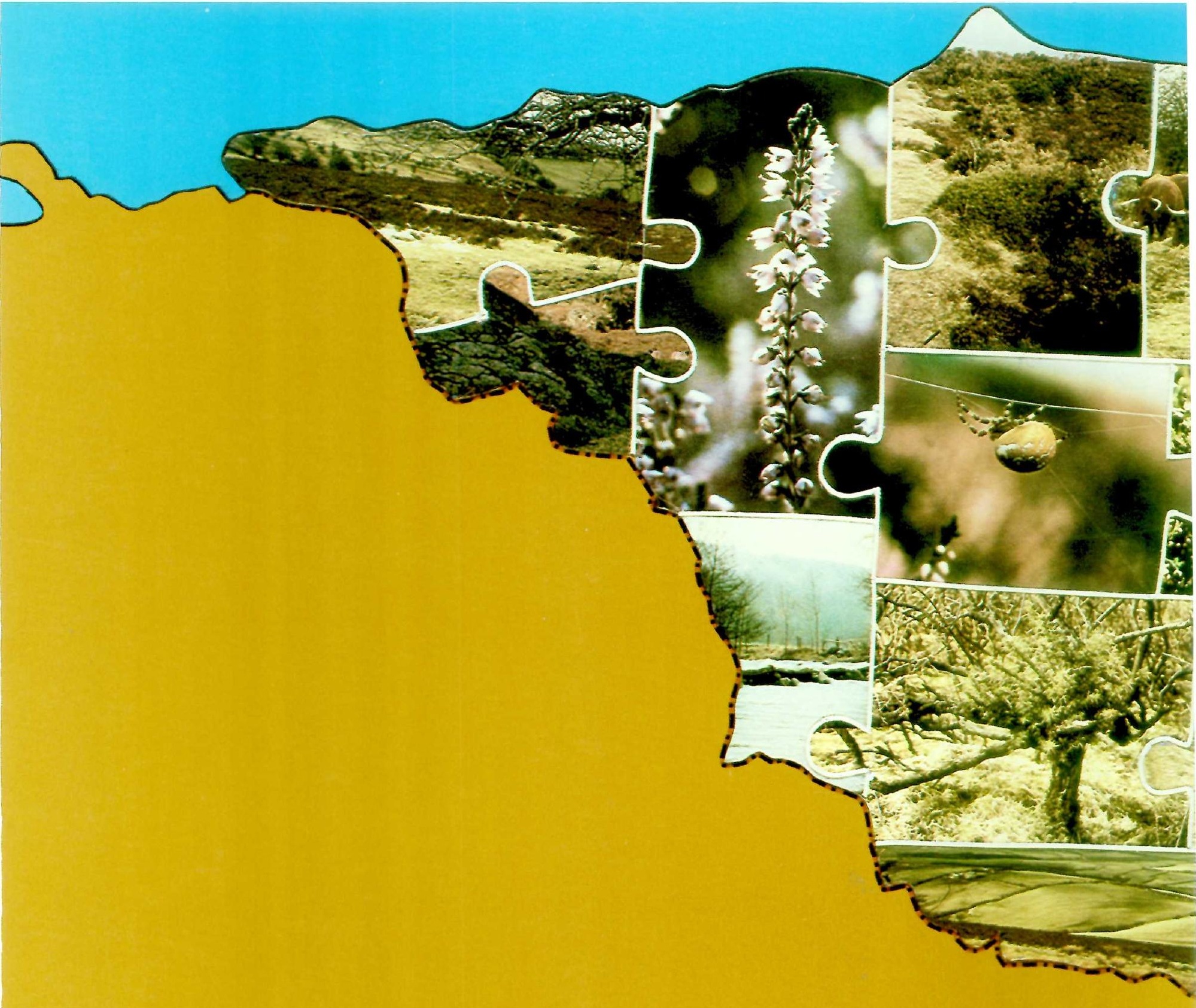

ISBN 0904282791

$£ 4.50$ net 